\title{
DESENVOLVIMENTO E AVALIAÇÃO DE DOIS INJETORES DE FERTILIZANTES TIPO VENTURI
}

\author{
RICARDO NICOLÁS ZÁRATE ROJAS \\ Engenheiro Agrónomo
}

Orientador: Prof. Dr. TARLEI ARRIEL BOTREL

\begin{abstract}
Dissertação apresentada à Escola Superior de Agricultura "Luiz de Queiroz", da Universidade de São Paulo, para obtenção do titulo de Mestre em Agronomia, Área de Concentração: Irrigação e Drenagem.
\end{abstract}

PIRACICABA

Estado de São Paulo - Brasil

Abril - 1995 
Fictia cataloorafica preparada pela Secaúa de Livros da Divisáa de Biblicteca e Documentacáa - PClolusf

\footnotetext{
Zárate Fojas, Ficardo Nicolas

Zjod Desenvolvimento e avaliacáo de dois irsjetores de fertilizantes tipo venturi. Firacicaba, 1995. b70. ilus.

Diss. (Mestre) - ESALQ

Biblicoratia.

1. Fertirrigacara 2. Injetar - Desenvalvimenta I. Eg cala Suberiar de Aoricultura Luiz de Quesroz, Firacica ba

CDD 631.7
} 


\section{DESENVOLVIMENTO E AVALIAÇĀO DE DOIS INJETORES DE FERTILIZANTES TIPO VENTURI}

\section{RICARDO NICOLÁS ZÁRATE ROJAS}

Aprovado em : 4.05 .95

Comissão julgadora

Prof. Dr. José Antônio Frizzone

ESALQ/USP.

Prof. Dr. Tarlei Arriel Botrel ESALQ/USP.

Prof. Dr. Reges Eduardo Franco Teodoro UFU.

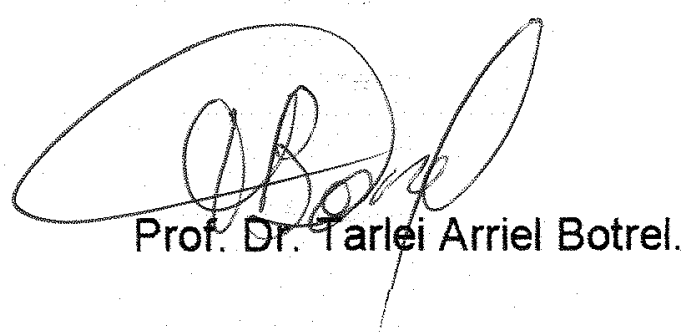


Aos meus pais, Dario e Noelia e a todos os meus familiares.

\section{OFEREÇO.}

À minha esposa Verónica e ao nosso filho Nicolás.

\section{DEDICO.}




\section{AGRADECIMENTOS}

À Deus pela fé e perseverança concedidas em todos os momentos.

À Universidade Nacional de Asunción pela oportunidade oferecida e concessão de recursos financieros, para a realização deste curso de mestrado.

À Escola Superior de Agricultura "Luiz de Queiroz", por intermédio do Departamento de Engenharia Rural, pela acolhida e efetivo apoio concedidos.

À Coordenadoria de Aperfeiçnamento de Pessoal de Ensino Superior (CAPES), pela contribuição financeira durante a realização do curso.

Ao Professor Dr. Tarlei Arriel Botrel, pela orientação e desinteressada amizade no decorrer do curso.

Ao Professor Dr. José Antônio Frizzone, pelas valiosas sugestões e colaborações apresentadas.

À bibliotecária Kátia Maria de Andrade Ferraz, por suas valiosas contribuições.

Aos colegas Andrés Lai Reyes, Luis Fernando Servín Villalba e Julio Renán Paniagua Alcaraz, pelo apoio incondicional e desinteressado.

Enfim a todos aqueles que, direta ou indiretamente, tenham contribuído para o êxito deste trabalho. 
SUMÁRIO

Página

LISTA DE FIGURAS ...............................................................................

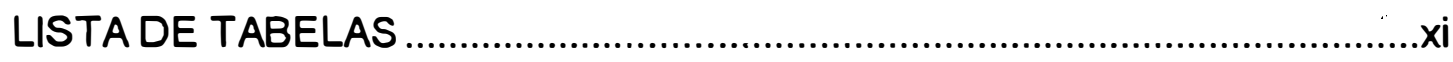

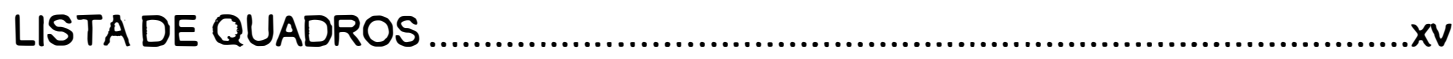

LISTA DE SÍMBOLOS ...........................................................................

RESUMO

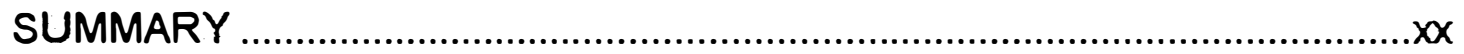

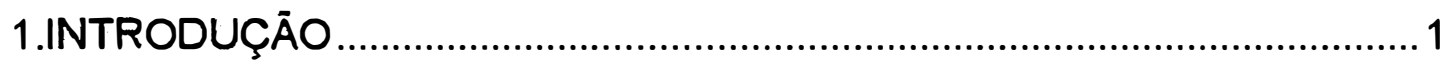

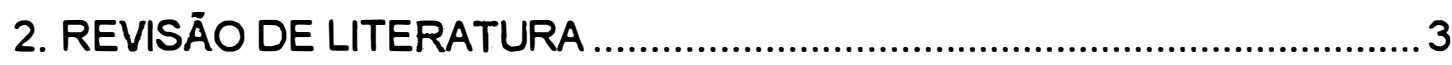

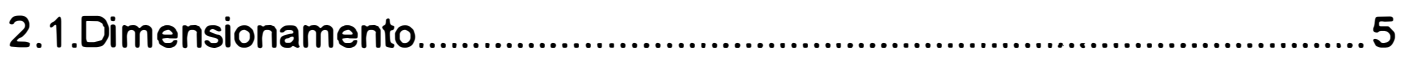

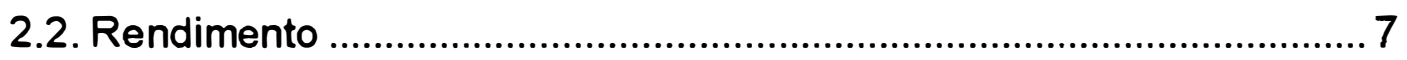

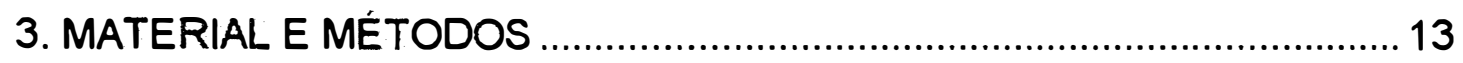

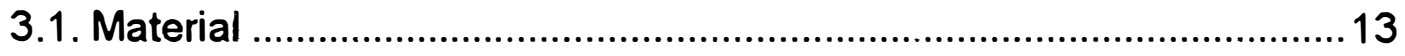

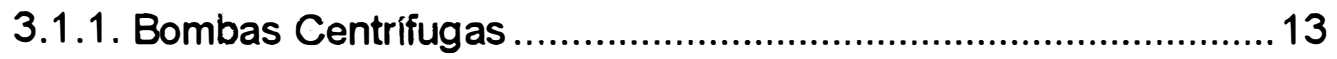

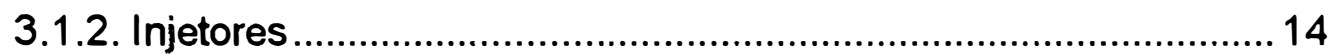

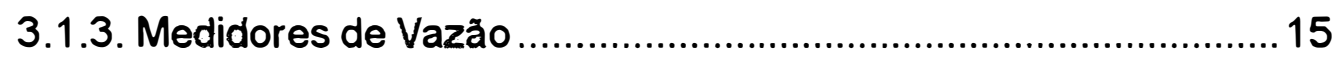

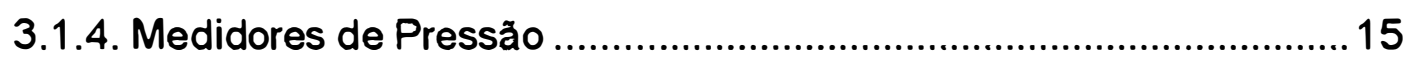

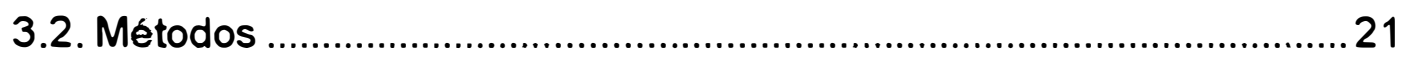

3.2.1. Esquema de montagem dos equipamentos ............................. 21

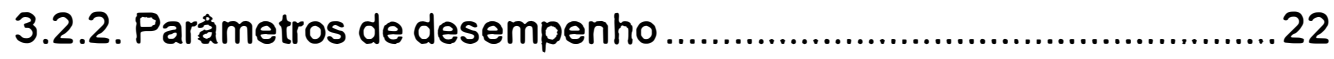

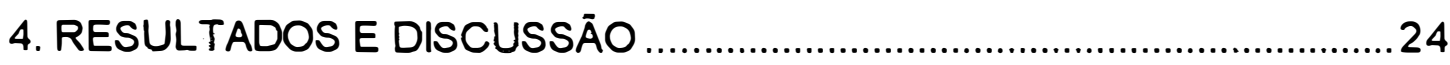

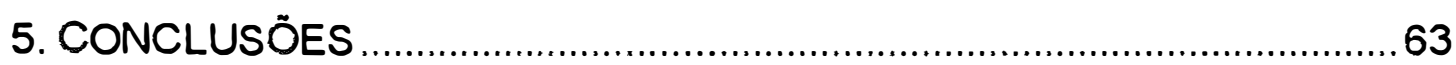

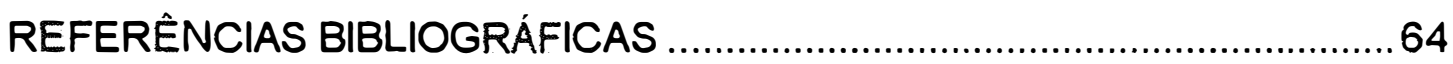




\section{LISTA DE FIGURAS}

Página

Figura 1 Dimensões do injetor Venturi desenvolvido por DENICULI et al. (1992).............................................................. 7

Figura 2 Variação dos coeficientes $\mu$ e $\delta$ para os diversos

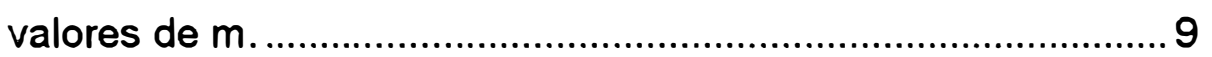

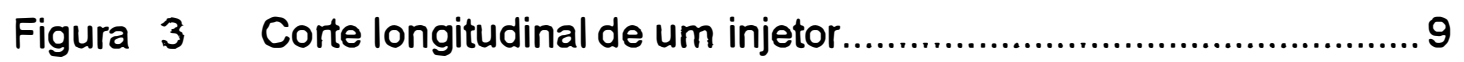

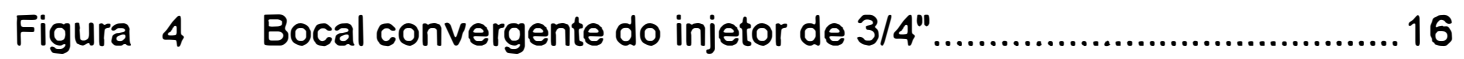

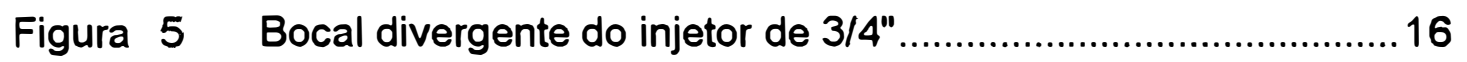

Figura 6 Bocal convergente do injetor de 1".........................................17

Figura 7 Bocal divergente do injetor de 1"...........................................17

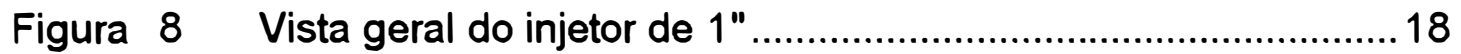

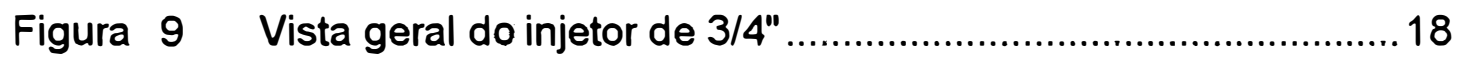

Figura 10 Vista das partes do injetor de 1" .............................................19

Figura 11 Vista das partes do injetor de 3/4"...........................................19

Figura 12 Vista dos bocais convergente (esquerda), e divergente (direita) do injetor de 1" ..........................................20

Figura13 Vista mostrando o detalhe do interior do injetor de 1" ..............20

Figura14 Vista da montagem dos equipamentos ..................................21

Figura 15 Curva de vazão vs tensão de sucção para o injetor de 3/4" sob pressão de alimentação de 20 m.c.a. e diferencial de pressão de 10 m.c.a. 
Página

Figura 16 Curva de tensão de sucção vs rendimento do injetor de 3/4"sob pressão de alimentação de 20 m.c.a. e diferencial de pressão de 10 m.c.a.

Figura 17 Curva de vazão vs tensão de sucção para o injetor de 3/4", sob pressão de alimentação de 30 m.c.a. e diferencial de pressão de 15 m.c.a.

Figura18 Curva de tensão de sucção vs rendimento do injetor de 3/4"sob pressão de alimentação de 30 m.c.a. e diferencial de pressão de 15 m.c.a. 30

Figura 19 Curva de vazão vs tensão de sucção para o injetor de 1"sob pressão de alimentação de 20 m.c.a. e diferencial de pressão de 10 m.c.a

Figura 20 Curva da tensão de sucção vs rendimento do injetor de 1" sob pressão de alimentação de 20 m.c.a.,e diferencial de pressão de 10 m.c.a.

Figura 21 Curva de vazão vs tensão de sucção para o injetor de 1" sob pressão de alimentação de 30 m.c.a. e diferencial de pressão de 15 m.c.a. 34

Figura 22 Curva da tensão de sucção vs rendimento do injetor de 1" sob pressão de alimentação de 30 m.c.a. e diferencial de pressão de 15 m.c.a.

Figura23 Vazão de sucção vs diferencial de pressão do injetor de $3 / 4$ " sob 40 m.c.a. de pressão de alimentação 36 
Página

Figura 24 Curva do diferencial de pressão vs rendimento do injetor de 3/4" sob pressão de alimentação de 40 m.c.a. 36

Figura25 Vazão de sucção vs diferencial de pressão do injetor de 3/4" sob 35 m.c.a de pressão de alimentação. 38

Figura26 Curva do diferencial de pressão vs rendimanto do injetor de 3/4" sob pressãr. de alimentação de 35 m.c.a. 38

Figura 27 Vazão de sucção vs diferencial de pressão do injetor de 3/4" sob 30 m.c.a. de pressão de alimentação. 40

Figura 28 Curva do diferencial de pressão vs rendimento do injetor de 3/4" sob pressão de alimentação de 30 m.c.a.

Figura29 Vazão de sucção vs diferencial de pressão do injetor de 3/4" sob 25 m.c.a de pressão de alimentação.

Figura30 Curva do diferencial de pressão vs rendimento do injetor de 3/4" sob pressão de alimentação de 25 m.c.a.

Figura 31 Vazão de sucção vs diferencial de pressão do injetor de 3/4" sob 20 m.c.a. de pressão de alimentação

Figura 32 Curva do diferencial de pressão vs rendimento do injetor de 3/4" sob pressão de alimentação de 20 m.c.a. 
Página

Figura33 Vazão de sucção vs diferencial de pressão do injetor de 3/4" sob 15.m.c.a. de pressão de alimentação. 46

Figura34 Curva do diferencial de pressão vs rendimento do injetor de 3/4" sob pressão de alimentação de 15 m.c.a. 46

Figura35 Vazão de sucção vs diferencial de pressão do injetor de 3/4" sob 10 m.c.a. de pressão de alimentação.

Figura36 Curva do diferencial de pressão vs rendimento do injetor de 3/4" sob pressão de alimentação de 10 m.c.a. 48

Figura37 Vazão de sucção vs diferencial de pressão do injetor de 1" sob 40 m.c.a. de pressão de alimentação. 50

Figura38 Curva do diferencial de pressão vs rendimento do injetor de 1" sob pressão de alimentação de 40 m.c.a. 50

Figura 39 Vazão de sucção vs diferencial de pressão do injetor de 1" sob 35 m.c.a.de pressão de alimentação 52

Figura 40 Curva do diferencial de pressão vs rendimento do injetor de 1" sob pressão de alimentação de 35 m.c.a.

Figura 41 Vazão de sucção vs diferencial de pressão do injetor de 1" sob 30 m.c.a. de pressão de alimentação.

Figura 42 Diferencial de pressão vs rendimento do injetor de 1" sob pressão de alimentação de 35 m.c.a.

Figura 43 Vazão de sucção vs diferencial de pressão do injetor de 1" sob 25 m.c.a. de pressão de alimentação. 56 
Página

Figura 44 Diferencial de pressão vs rendimento do injetor de 1" sob pressão de alimentação de 25 m.c.a. 56

Figura 45 Vazão de sucção vs diferencial de pressão do injetor de 1" sob 20 m.c.a. de pressão de alimentação.

Figura 46 Diferencial de pressão vs rendimento do injetor de 1" sob pressão de alimentação de 20 m.c.a.

Figura 47 Vazão de sucção vs diferencial de pressão do injetor de 1" sob 15 m.c.a. de pressão de alimentação 60

Figura 48 Diferencial de pressão vs rendimento do injetor de 1" sob pressão de alimentação de 15 m.c.a. 60

Figura 49 Vazão de sucção vs diferencial de pressão sob 10 m.c.a de pressão de alimentação

Figura50 Curva do diferencial de pressão vs rendimento do injetor de 1" sob pressão de alimentação de 10 m.c.a. 


\section{LISTA DE TABELAS}

Página

Tabela 1 Tensão de sucção, vazão de sucção, vazão de alimentação e rendimento para o injetor de 3/4", succionando água, à pressão de alimentação de 20 m.c.a. e diferencial de pressão relativo de 10 m.c.a.

Tabela 2 Tensão de sucção, vazão de sucção, vazão de alimentação e rendimento para o injetor de 3/4", succionando água, à pressão de alimentação de 30 m.c.a., e diferencial de pressão de 15 m.c.a.

Tabela 3 Tensão de sucção, vazão de sucção, vazão de alimentação e rendimento para o injetor de 1", succionando água, à pressão de alimentação de 20 m.c.a. e diferencial de pressão de 10 m.c.a.

Tabela 4 Tensão de sucção, vazão de sucção, vazão de alimentação, e rendimento para 0 injetor de 1", succionando água, à pressão de alimentação de 30 m.c.a., e diferencial de pressão de 15 m.c.a.

Tabela 5 Pressão à jusante, vazão de sucção, vazão de alimentação e rendimento para 0 injetor de 3/4", succionando água, à pressão de alimentação de 40 m.c.a., sob tensão de sucção de 0,5 m.c.a. 35 
Tabela 6 Pressão à jusante, vazão de sucção, vazão de alimentação e rendimento para o injetor de 3/4", succionando água, à pressão de alimentação de 40 m.c.a. e sob tensão de sucção de 0,5 m.c.a.

Tabela 7 Pressão à jusante, diferencial de pressão, vazăo de sucção, vazão de alimentação e rendimento do injetor de $3 / 4 "$, succionando água, à pressão de alimentação de 30 m.c.a. sob tensão de sucção de 0,5 m.c.a. 39

Tabela 8 Pressão à jusante, diferencial de pressão, vazăo de sucção, vazão de alimentação e rendimento do injetor de 3/4", à pressão de alimentação de 25 m.c.a. sob tensão de sucção de 0,5 m.c.a

Tabela 9 Pressão à jusante, diferencial de pressão, vazão de sucção, vazão de alimentação e rendimento do injetor de $3 / 4^{\prime \prime}$, succionando água, à pressão de alimentação de 10 m.c.a. sob tensão de sucção de 0,5 m.c.a.

Tabela10 Pressão à jusante, diferencial de pressão, vazão de sucção, vazão de alimentação e rendimento do injetor 3/4", succionando água, à pressão de alimentação de 15 m.c.a. sob tensão de sucção de 0,5 m.c.a. 
Página

Tabela11 Pressão à jusante, diferencial de pressão, vazão de alimentação e rendimento do injetor de 3/4", succionando água, à pressão de alimentação de 10 m.c.a. sob tensão de sucção de 0,5 m.c.a.

Tabela12 Pressão à jusante, diferencial de pressão, vazão de alimentação, e rendimento do injetor de 1", succionando água, à pressão de alimentação de 40 m.c.a. sob tensão de sucção de 0,5 m.c.a

Tabela13 Pressão à jusante, diferencial de pressão, vazão de alimentação e rendimento do injetor de 1", succionando água, à pressão de alimentação de 35 m.c.a. sob tensão de sução de 0,5 m.c.a

Tabela14 Pressão à jusante, diferencial de pressão, vazão de sucção, vazão de alimentação, e rendimento do injetor de 1", succionando água, à pressão de alimentação de 30 m.c.a. sob tensão de sucção de 0,5 m.c.a.

Tabela15 Pressão à jusante, diferencial de pressão, vazão de sucção, vazăo de alimentação e rendimento do injetor de 1", succionando água, à pressão de alimentação de 25 m.c.a. sob tensão de sucção de 0,5 m.c.a. 
Página

Tabela16 Pressão à jusante, diferencial de pressão, vazão de sucção, vazão de alimentação e rendimento do injetor de 1", succionando água, à pressão de alimentação de 20 m.c.a. sob tensão de sucção de 0,5 m.c.a.

Tabela17 Pressão à jusante, diferencial de pressão, vazão de sucção, vazão de alimentação e rendimento do injetor de 1", succionando água, à pressão de alimentação de 15 m.c.a. sob tensão de sucção de 0,5 m.c.a. 59

Tabela18 Pressão à jusante, diferencial de pressão, vazăo de sucção, vazão de alimentação, e rendimento do injetor de 1" succio-nando água, à pressão de alimentação de 10 m.c.a. sob tensão de sucção de 0,5 m.c.a. 


\section{LISTA DE QUADROS}

Página

Quadro 1 Características das bombas centrífugas ................................13

Quadro 2 Equações de regressão da vazão em função da

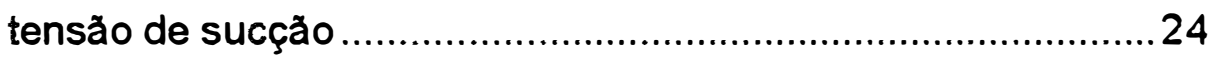

Quadro3 Equações de regressão da vazão em função do diferencial de pressão para o injetor de 3/4"...............................26

Quadro 4 Equações de regresão da vazão em função do diferencial de pressão para o injetor de 1" 


\section{LISTA DE SÍMBOLOS}

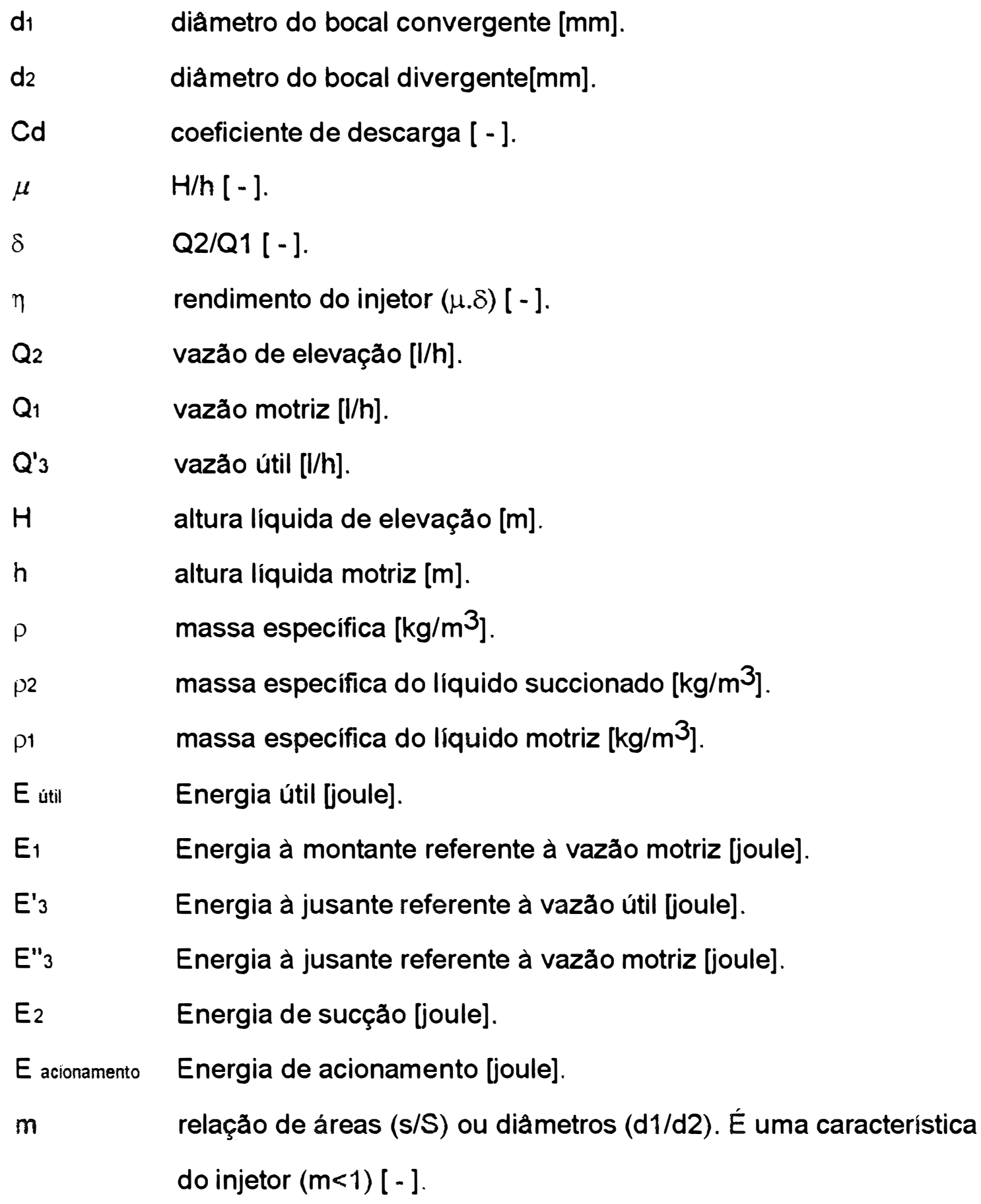


xvii

$\begin{array}{ll}\text { Inf. } & \text { inferior }[-] . \\ \text { Sup. } & \text { superior }[-] . \\ \text { s } & \text { área do bocal convergente }\left[\mathrm{m}^{2}\right] . \\ S & \text { area do bocal divergente }\left[\mathrm{m}^{2}\right] . \\ \text { V } & \text { velocidade do fluído }[\mathrm{m} / \mathrm{s}] . \\ \text { P } & \text { pressão }\left[\mathrm{N} / \mathrm{m}^{2}\right] \\ \theta & \text { volume }\left[\mathrm{m}^{3}\right] . \\ \Delta T & \text { energia por unidade de tempo [ }] . \\ \text { m.c.a. } & \text { metros de coluna de água }[\mathrm{m}] . \\ \text { vs. } & \text { versus }[- \text { ]. } \\ \text { " } & \text { polegada } \\ \mathrm{KPa} & \text { quilo Pascal }\end{array}$




\title{
DESENVOLVIMENTO E AVALIAÇÃO DE DOIS INJETORES DE FERTILIZANTES TIPO VENTURI
}

\author{
Autor : RICARDO NICOLÁS ZÁRATE ROJAS \\ Orientador: PROF. DR. TARLEI ARRIEL BOTREL
}

\section{RESUMO}

No presente traballho apresentam-se as metodologias de desenvolvimento e avaliação de dois injetores tipo Venturi, de 1" e 3/4".

Também apresentam-se os desenhos dos protótipos e as avaliações a que foram submetidos. As avaliações foram feitas no Laboratório de Irrigação do Departamento de Engenharia Rural da ESALQ/USP.

Os parâmetros de desempenho analizados foram: (1) vazão de sucção vs. tensão de sucção, (2) rendimento vs. tensão de sucção, (3) vazão de sucção vs. diferencial de pressão, e (4) rendimento vs. diferencial de pressão.

O maior rendimento obtido para o injetor de 1 " foi $10,46 \%$ sob pressão de alimentação de 10 m.c.a., e para o de $3 / 4$ " foi de $8,21 \%$ sob a mesma pressão de alimentação.

Os injetores diminuem a sua vazão de sucção, com o aumento da tensão de sucção. Ambos os injetores, nas pressões de alimentação de 40, 
35, 30, 25 e 20 m.c.a., possuem limites, a partir dos quais, mesmo que se aumente o diferencial de pressão, não aumenta a vazão de sucção. Já nas pressões de alimentação de 15 e 10 m.c.a., não foram encontrados tais limites e manteve-se linear a relação entre vazão de sucção e diferencial de pressão. 


\title{
DEVELOPMENT AND EVALUATION OF TWO INJECTOR FERTILIZER VENTURI TYPE
}

\author{
Author: RICARDO NICOLÁS ZÁRATE ROJAS \\ Adviser: PROF. DR. TARLEI ARRIEL BOTREL
}

\section{SUMMARY}

The aims of this study were to develop and evaluate two injectors fertilizer Venturi type of 1" and 3/4".

The evaluation was done in the Irrigation Laboratory of Rural Engineering Department at ESALQ - University of São Paulo.

The parameters analyzed were: (1) suction flow vs. suction pressure, (2) efficiency vs. suction pressure, (3) suction flow vs. differential pressure, and (4) efficiency vs. differential pressure. Different range of pressure and flow were used.

The major efficiency obtained for the 1" injector was $10.46 \%$ under $100 \mathrm{kPa}$ pressure, and $8.21 \%$ for the $3 / 4$ " injector at the same pressure.

The suction flow of both injectors decreased as thio suction pressure increased. The pressures head before the injector apparatus were 400 , $350,300,250,200 \mathrm{kPa}$. Each pressure has its own limit on the differential 
pressure, at pressures ranging from 100 to $150 \mathrm{kPa}$ no limits were found, a linear relation between suction flow and differential pressure was detected. 


\section{INTRODUÇÃO}

A aplicação de fertilizantes, via água de irrigação, é vantajosa, quando se usa irrigação de alta frequência, pois possibilita a aplicação da quantidade exata de fertilizante que o vegetal demanda para seu ciclo vegetativo.

De acordo com SNE (1988), a injeção de fertilizante, através da água de irrigação, pode executar-se por diversos métodos. Leve-se emconta o princípio de que, em sistemas de irrigação pressurizados, a solução de fertilizante injetada tem que superar a pressão interna da rede. Os métodos mais comuns para a injeção de fertilizante em sistemas de irrigação são: elevação da pressão da solução fertilizante por bombeamento, sucção pela pressão negativa, e diferencial de pressão.

A sucção pela pressão negativa é obtida através do injetor Venturi. FRIZZONE et al.(1994) definem o injetor Venturi como um dispositivo metálico, ou de PVC, com uma seção convergente, seguida de um estrangulamento e de uma seção divergente gradual, para diâmetro igual ao da tubulação a ele conectada. O princípio de funcionamento baseia-se na transformação da energia de pressão da água na tubulação em energia cinética, quando a água passa pela seção estrangulada do Venturi, que novamente se transforma em energia de pressão, ao voltar à tubulação principal. O Venturi aumenta a velocidade da água na seção estrangulada, provocando queda de 
pressão. Devidamente dimensionado, ocasiona a sucção do fertilizante colocado num reservatório aberto, injetando-o na rede de irrigação.

SHANI \& SAPIR (1986) citam, como vantagens, o mecanismo ser simples, e não apresentar partes móveis. A solução é contida em um tanque aberto feito de plástico; sob condições operacionais estáveis, a taxa de diluição é constante. Uma ampla variedade de modelos é possível e os custos são baixos, em comparação aos equipamentos alternativos. Como limitações, têm-se uma grande perda na pressão de bombeamento, na maioria dos modelos (no mínimo um terço da pressão de entrada) e sensibilidade a variações de pressão e vazão; além disso, variação nas condições de operação pode ocasionar uma grande variação na taxa de mistura.

Procurando dar subsídios aos irrigantes, apresenta-se uma metodologia para a construção de dois tamanhos de injetores de fertilizante tipo Venturi (3/4 e 1") em PVC, modelados em torno. Apresentam-se também as avaliações a que foram submetidos no laboratório de Irrigação da ESALQ/USP. 


\section{REVISÃO DE LITERATURA}

Inicialmente, os Tubos de Venturi só eram utilizados para se fazerem medições de vazão. Segundo DELMÉE (1983), o primeiro trabalho desenvolvido sobre tais medidores foi realizado por G.B. Venturi, em 1797, em suas pesquisas experimentais sobre o princípio de comunicação lateral do movimento nos fluidos, aplicado à interpretação de diferentes fenômenos hidráulicos. Somente 90 anos depois, Clemens Herschel desenvolveu o tubo de Venturi.

Os aparelhos a jato valem-se do princípio de Venturi e eles são definidos, segundo TROSKOLANSKI (1977), como dispositivos apropriados para, simultaneamente, aspirar e recalcar um fluido (líquido, gás ou vapor) ou uma mistura fluido-sólido, por aplicação prática do fenômeno de Venturi. Para tanto, utiliza-se um órgão de restrição seccional à passagem de corrente fluida, alimentado por um outro fluido qualquer, denominado fluido primário ou fluido motor. O citado autor divide os aparelhos a jato em dois grupos, ejetores e injetores. Os ejetores prestam-se a aspirar um fluido de um local, sob pressão qualquer, e recalcá-lo para outro local, sujeito à pressão atmosférica ou ligeiramente superior a ela. Já os injetores são empregados para recalcar um fluido para um local sujeito a uma pressão sempre superior à pressão atmosférica. 
De acordo com FEITOSA FILHO \& ARRUDA (1994), no Brasil só se dispõe de injetores importados, fabricados em PVC, polietileno ou acrílico, e, por isso, só recomendados para uso em sistema de irrigação de baixa pressão. $O$ trabalho desses autores teve como objetivo divulgar um protótipo de um injetor "Tipo Venturi", fabricado com tubos e chapa metálica, e a metodologia para sua construção e dimensionamento, o qual apresenta potencial para ser utilizado tanto na irrigação de baixa pressão, quanto na de média e alta pressão.

Ainda, segundo os autores citados, os parâmetros que se devem conhecer, para o dimensionamento do injetor, são: vazão total do sistema de irrigação (ou vazão que deve passar pelo injetor se instalado em paralelo à linha de irrigação), pressão de serviço no local próximo ao início da seção convergente do injetor, altura em que deve ser instalado o equipamento em relação ao recipiente contendo a solução e uma pressão negativa na seção estrangulada do injetor a ser atribuída.

Segundo HERNÁNDEZ et al. (1987), o fluxo de fertilizante injetado na rede terá uma relação direta com a pressão da água na entrada do mecanismo, com uma pressão mínima em torno de 15 m.c.a.. Nos modelos usuais, tal vazão situa-se entre 50 e 3.000 l/h. A vazão mínima a passar pelo aparelho depende da sua capacidade e varia desde $1 \mathrm{~m}^{3} / \mathrm{h}$, para os modelos de $1 "$ (uma polegada), a mais de $20 \mathrm{~m}^{3} / \mathrm{h}$, para alguns de 2", de alta capacidade de sucção. 0 mesmo autor explica que, nos catálogos comerciais, a capacidade de sucção do Venturi refere-se à água pura. Essa capacidade será reduzida na medida em que a densidade da solução fertilizante aumentar.

De acordo com PIZARRO (1990), anos atrás, era frequiente intercalar o injetor Venturi, não em paralelo, mas na própria rede, com o 
inconveniente de ocasionar perdas de carga em torno de $30 \%$ da pressão. Para se instalar o injetor Venturi, deve-se coloca-lo em paralelo com a tubulação de irrigação. Nesta, uma válvula produz um diferencial de pressão, que dirige parte da água ao circuito do injetor. Essa válvula pode ser evitada, aproveitando qualquer elemento do cabeçal que crie perdas de pressão (reguladores, filtros, etc.).

FEITOSA FILHO (1990), necessitando trabalhar com um desses instrumentos e não o encontrando no mercado, aproveitou parte das recomendações citadas por DELMÉE (1983), para a construção do medidor de vazão "Tipo Venturi", e construiu alguns desses injetores utilizando tubos e chapas metálicas.

FERREIRA (1994), estudando dois injetores Venturi, chegou às seguintes conclusões: a vazão de sucção aumenta com o aumento do diferencial de pressão, sendo constante a pressão de alimentação; a vazão de sucção diminui com o acréscimo da pressão de alimentação, mantendo-se constante 0 diferencial de pressão, e a vazão de sucção aumenta com o aumento da pressão relativa de sucção, para todos os casos por ele estudados.

\subsection{Dimensionamento}

De acordo com URQUHART (1950), o ângulo de convergência do venturímetro é de $21^{\circ}$, o diâmetro da garganta, entre a metade e um quarto do diâmetro da tubulação de entrada e o ângulo de divergência, entre 5 e $7^{\circ}$.

Para BALLOFETT et al. (1955), nos medidores Venturi, o diâmetro da garganta é geralmente $1 / 3$ do diâmetro da tubulação na qual está 
instalado. A seção convergente pode ter um comprimento de 2,5 vezes 0 diâmetro da tubulação, o qual corresponde a um ângulo de $15^{\circ}$ enquanto o divergente, um comprimento de 7,5 diâmetros, com o que se obtém um ângulo ótimo de $5^{\circ}$.

Segundo CARLIER (1968), o rendimento do bocal divergente jamais alcança o valor unitário e permanece compreendido entre 0,7 e 0,85 (70 a $85 \%)$.

De acordo com RUSSELL (1971), no desenho original de Herschel, a porção convergente do medidor varia de 2 a 2,5 vezes o diâmetro da tubulação. A porção divergente tem um ângulo central de $5^{\circ}$, e a relação entre d1 e d2 é de 3:1. Essas proporções para o dispositivo já não seguem o padrão de Herschel e a relação entre d1 e d2 varia de 1,5 a 4,0, sendo 2,0 a relação mais freqüente.

Para VENNARD \& STREET (1978), um medidor Venturi consiste de um cone de entrada lisa, com ângulo em torno de $20^{\circ}$, um cilindro de seção curta, e um cone difusor, com ângulo entre $5^{\circ}$ e $7^{\circ}$, com a finalidade de minimizar a perda de carga. Segundo AZEVEDO NETTO \& ALVAREZ (1988), nos bocais convergentes, a descarga é máxima para um ângulo igual a 13030' com um $\mathrm{Cd}=0,94$. As experiências de Venturi demonstram que um ângulo de divergência de $5^{\circ}$, combinado com um comprimento de tubo igual a cerca de nove vezes o diâmetro da seção estrangulada, permite os mais altos coeficientes de descarga.

Na Figura 1, apresenta-se o injetor Venturi desenvolvido por DENÍCULl et al.(1992), para a aplicação de potássio na água de irrigação. O injetor foi construido com base nas dimensões do venturímetro clássico. Com 
relação à estrutura, os bocais convergente e divergente, junto à garganta, formam um corpo único.

FEITOSA FILHO \& ARRUDA (1994) adotaram ângulo convergente de $21^{\circ}$ e divergente de $11^{\circ}$, sendo que DELMÉE (1983) recomenda o mesmo ângulo convergente $\left( \pm 1^{\circ}\right)$ e um ângulo divergente entre 7 e $15^{\circ}$. É importante destacar que as medidas propostas por DELMÉE (1983) aplicam-se, para um tubo de Venturi clássico, isto é, com o objetivo especifico de "medir vazőes".

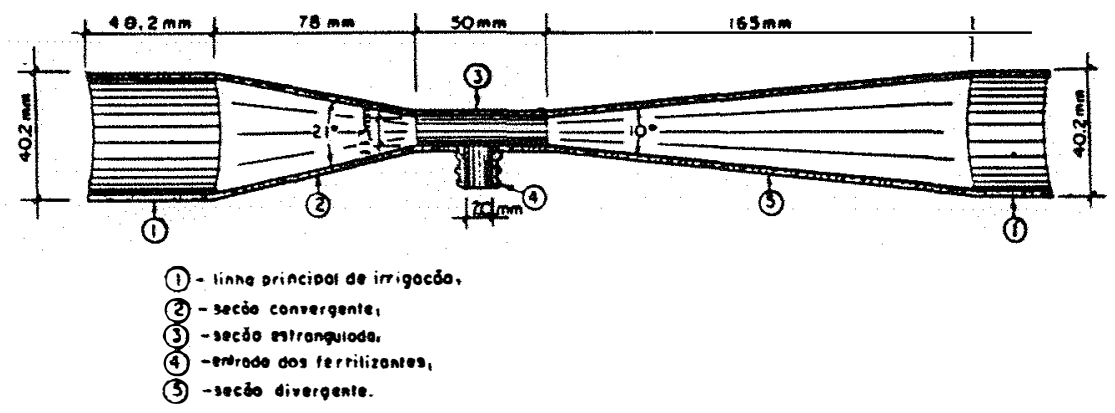

Figura 1 - Dimensőes do injetor Venturi desenvolvido por DENICULI et al. (1992).

\subsection{Rendimento}

Segundo FLÜGEL'1, citado por HIRSCHMANN (1958), qualquer ejetor de água tem como valor caracteristico o quociente $\mu$, dado por: 
$\mu=\frac{P_{s}-P_{a}}{P_{e}-P_{s}}$

o mesmo autor, define também o coeficiente $\delta$, dado por

$$
\delta=\frac{Q_{2}}{Q_{1}}
$$

e, o rendimento $\eta$ dado por:

$$
\eta=\mu . \delta
$$

CARLIER (1968) chega à mesma expressão de Flüguel para o rendimento global do ejetor, admitindo comuns o fluído motor e o de sucção, sendo:

$$
\eta=\frac{Q_{2} \cdot H}{Q_{1} \cdot h}=\mu \cdot \delta
$$

O autor assume que as curvas caracteristicas de $H\left(Q_{2}\right)$ e $\eta$ $\left(Q_{2}\right)$, sob uma carga motriz $(h)$ constante, são semelhantes àquelas das bombas centrifugas, assim como também o rendimento é sempre pequeno, no máximo 0,3 . Para um dado ejetor, o rendimento máximo é obtido para o valor máximo do produto $\mu \cdot \delta$, isto é, para $\mu=\mu_{0} / 2$ e $\delta=\delta_{0} / 2$, sendo $\mu_{0}$ o valor de $\mu$ para $\delta=0$ e $\delta_{0} \circ$ valor de $\delta$ para $\mu=0$.

Também para o citado autor, a razão $m=s / S$ é um parâmetro característico do ejetor e apresenta um gráfico (Figura 2) de $\mu(\delta)$ e $\eta(\delta)$ para 
quatro valores de $\mathrm{m}$, que se mantiveram constantes. De acordo com o gráfico, o valor de $m=0,25$ é o que fornece maior rendimento.

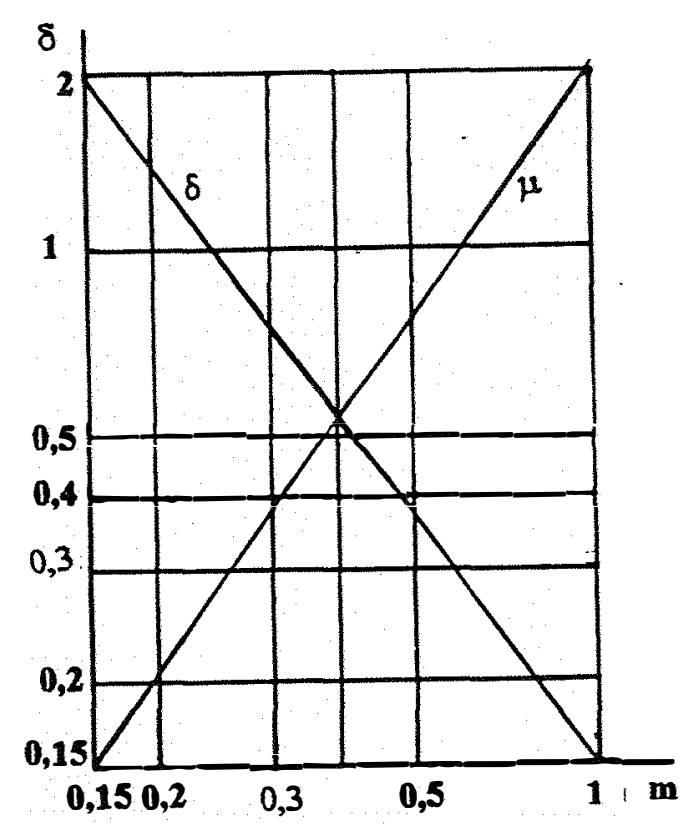

Figura 2 - Variaçåo dos coeficientes $\mu$ e $\delta$ para os diversos valores de $m$.

Segundo FUCHSLOCHER (1954), o rendimento nos ejetores pequenos é da ordem de 0,1 a 0,15 , nos maiores é de 0,22 e, nos muitos grandes até 0,25 , no máximo.

OLIVEIRA (1993) apresenta uma metodologia para a avaliação dos injetores, de acordo com o seguinte esquema:

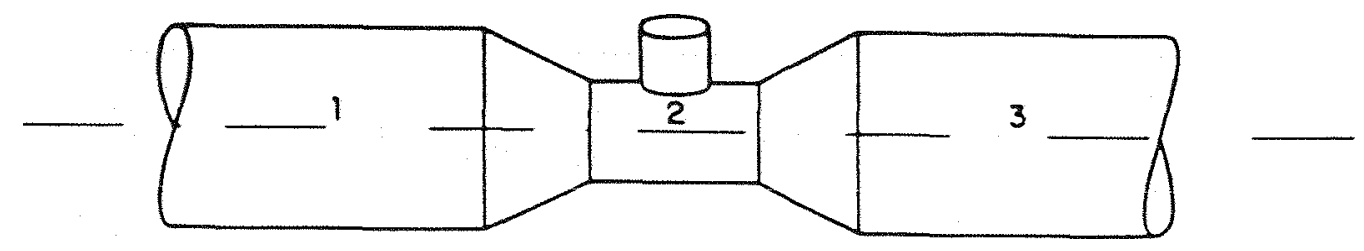

Figura 3 - Corte longitudinal de um injetor 
Onde:

1 é ponto de alimentação do injetor;

2 é ponto de sucção de ar ou água e

3 é ponto de descarga de água .

A partir da Figura 3, e pela lei da conservação da energia, temse:

$E_{1}+E^{\prime} 2=E 3$

sendo,

E1 a energia total em 1;

$E^{\prime} 2$ a energia total em 2 e

E3 a energia total em 3.

Em se tratando do processo isotérmico, as formas de energia envolvidas são: a cinética; a piezométrica e a geométrica, sendo que a posição do injetor, na horizontal, iguala a energia de posição nos três pontos.

Como o objetivo principal é a avaliação da sucção realizada pelo injetor, e considerando E'2 como energia útil (energia para sucção), e E1 como energia total de acionamento, o rendimento será:

$\eta=E^{\prime} 2 / E_{1}$

ou ainda, 
$\eta=\frac{E c_{2}+E p_{2}}{E c_{1}+E p_{1}} 2$

onde,

Ec é a energia cinética $=1 / 2 \mathrm{~m}^{\prime} \cdot \mathrm{V}^{2} \mathrm{e}$

Ep é a energia piezométrica $=P \cdot \theta$

Considerando a energia por unidade de tempo $(\Delta T)$, tem-se:

$\frac{E c}{\Delta T}=\frac{m^{\prime} \cdot V^{2}}{2 \cdot \Delta T}$

$\frac{E p}{\Delta T}=\frac{P \cdot \theta}{\Delta T}$

Considerando que $\mathbf{m}=\rho \cdot \theta$, obtém-se

$$
\frac{E_{c}}{\Delta T}=\frac{\rho \cdot \theta \cdot V^{2}}{2 \cdot \Delta T}
$$

Dado que o volume por unidade de tempo $\theta / \Delta T$ é a vazão (Q), tem-se

$$
\frac{E c}{\Delta T}=\frac{\rho \cdot Q \cdot V^{2}}{2}
$$

Assim como também

$$
\frac{E p}{\Delta T}=P \cdot Q
$$

${ }^{2}$ Os indices sob as variáveis indicam as posições conforme a figura 3. 
A partir das equações 7,11 e 12 pode-se definir o rendimento

como

$$
\eta=\frac{\rho_{2} \cdot \frac{Q_{2} \cdot V_{2}^{2}}{2}+P_{2} \cdot Q_{2}}{\rho_{1} \cdot \frac{Q_{1} \cdot V_{1}^{2}}{2}+P_{1} \cdot Q_{1}}
$$

Sendo que $V=Q / A$ chega-se a

$$
\eta=\frac{\rho_{2} \cdot \frac{Q_{2}^{3}}{2 \cdot A_{2}^{2}}+P_{2} \cdot Q_{2}}{\rho_{1} \cdot \frac{Q_{1}^{3}}{2 \cdot A_{1}^{2}}+P_{1} \cdot Q_{1}}
$$




\section{MATERIAL E MÉTODOS}

Os injetores foram construídos por um torneiro da cidade de Piracicaba. Os ensaios dos mesmos foram conduzidos no Laboratório de Irrigação do Departamento de Engenharia Rural da Escola Surzrior de Agricultura "Luiz de Queiroz" da Universidarł de São Paulo, localizada no iMunicipio de Piracicaba, Estado de São Paulo, cujas coordenadas geográficas são: latitude $22^{\circ} 42^{\prime} 30^{\prime \prime}$, longitude 47030'00"W e altitude média de $576 \mathrm{~m}$.

\subsection{Material}

\subsubsection{Bombas Centrífugas}

Foram utilizadas duas bombas centrifugas de eixo horizontal, para a obtenção das pressões pré-establecidas, cujas caracteristicas são apresentadas no Quadro 1.

Quadro 1 - Características das bombas centrifugas

\begin{tabular}{|l|c|c|}
\hline Especificação & Bomba A & Bomba B \\
\hline Potência (CV) & 10 & 4 \\
Rotação (rom) & 3500 & 3490 \\
Vazão $\left(\mathrm{m}^{3} / \mathrm{h}\right)$ & 30 & 20 \\
Altura manométrica (m.c.a.) & 80 & 33 \\
\hline
\end{tabular}




\subsubsection{Injetores}

Foram construidos dois injetores de fertilizantes tipo Venturi de $3 / 4$ e 1" respectivamente. O material utilizado foi o PVC.

A metodologia de cálculo para o dimensionamento dos bocais foi a seguinte:

Para o injetor de $3 / 4^{\prime \prime}$, partiu-se da suposição de que haveria necessidade de um diferencial de pressão mínimo de $36 \mathrm{mca}$, e de uma vazão motriz de $1100 \mathrm{l} / \mathrm{h}$. Sendo que $Q=c d \cdot S \cdot \sqrt{2 \cdot g \cdot h}$, e adotando-se um $c d$ de 0,9 , pode-se obter a incógnita s (área do bocal convergente), cujo valor é $1,28 \cdot 10^{-5} \mathrm{~m}^{2}$. A partir da formula $S=\frac{\pi \cdot d^{2}}{4}$, obteve-se $\circ$ valor do diâmetro do bocal convergente, $\mathrm{d} 1=4,04 \mathrm{~mm}$.

Uma vez conhecido o valor d1, adotou-se o valor de $m=0,95$, para, dessa maneira, obter-se $\mathrm{d} 2$, a partir da relação $m=\frac{s}{S}=\frac{d 1^{2}}{d 2^{2}}$, resultando o valor de $\mathrm{d} 2=4,14 \mathrm{~mm}$.

Para o dimensionamento dos bocais do injetor de 1", seguiu-se a mesma metodologia do de $3 / 4^{\prime \prime}$. Só foi modificada a vazão motriz, adotando-se $3860 \mathrm{l} / \mathrm{h}$. Foram obtidos os diâmetros $\mathrm{d} 1=7,6 \mathrm{~mm}$ e d2 $=7,8 \mathrm{~mm}$.

Foi utilizado um ângulo convergente de $15^{\circ}$, para o injetor de $3 / 4^{\prime \prime}$, e de $14^{\circ}$, para o de $1^{\prime \prime}$. O ângulo divergente do injetor de $3 / 4^{\prime \prime}$ foi de $14^{\circ}$, e, para o de 1", foi de $12^{\circ}$. Tais ângulos foram establecidos em função da facilidade na construção dos bocais.

Adotou-se uma distância entre bocais, para ambos os casos, de 1,1 D. Os detalhes construtivos podem ser apreciados nas Figuras 4, 5, 6 e 7. 
A montagem dos bocais foi feita em conexões tipo "T" soldaveis, e adaptaram-se uniões solda-rosca de acordo com as Figuras 9, 10, 11,12, 13 e 14.

\subsubsection{Medidores de Vazão}

Para medir a vazão motriz, foi utilizado um medidor de vazăo magnético indutivo (CONAUT - 462), com limite máximo de medição de $8 \mathrm{~m}^{3} / \mathrm{h}$. Ele opera com um conversor de sinais CONAUT - $474(K=404)$.

O principio de funcionamento baseia-se na lei de FARADAY, que consiste na geração de um campo magnético, pela passagem de uma corrente elétrica entre duas bobinas; o condutor é o fluido de medição, e o diâmetro do tubo, igual ao comprimento.

O medidor apresenta precisão de $0,1 \%$, comprovada em ensaios realizados no Laboratório de Irrigação do Departamento de Engenharia Rural da ESALQ/USP.

\subsubsection{Medidores de Pressão}

A pressão de alimentação foi medida através do transdutor de pressão No. 726 , com capacidade de $5 \mathrm{kgf} / \mathrm{cm}^{2}$, conectado ao aparelho conversor interface No. 843 (indicador digital microprocessado).

Para medir a pressão de recalque, foi utilizado o transdutor de pressão No.664, com capacidade de $10 \mathrm{kgf} / \mathrm{cm}^{2}$, conectado ao aparelho conversor interface No. 193 (indicador digital microprocessado). Ambos os 
medidores tem uma precisão de $0,1 \%$ e foram calibrados antes de começar os ensaios.

A pressão de suç̧ão foi medida, utilizando-se um vacuômetro de coluna de mercúrio.
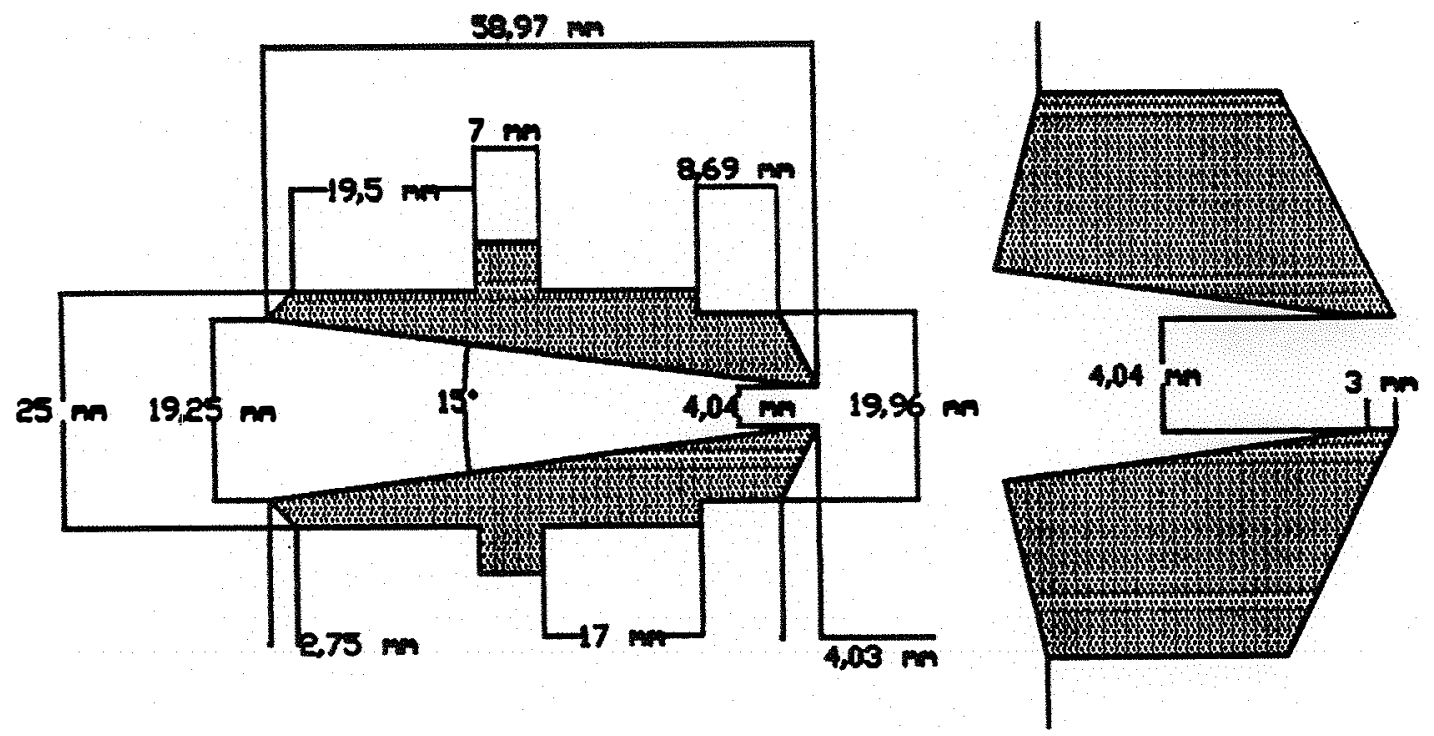

Figura 4 - Bocal convergente do injetor de 3/4"
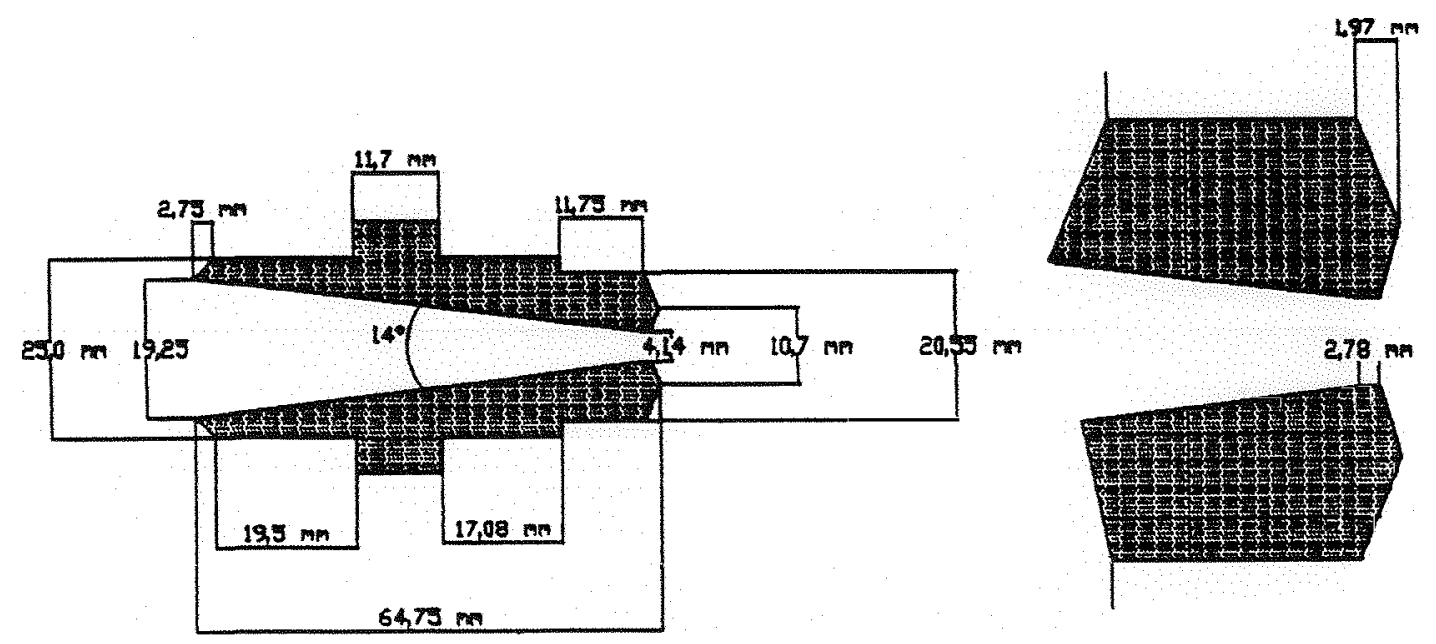

Figura 5 - Bocal divergente do injetor de 3/4" 


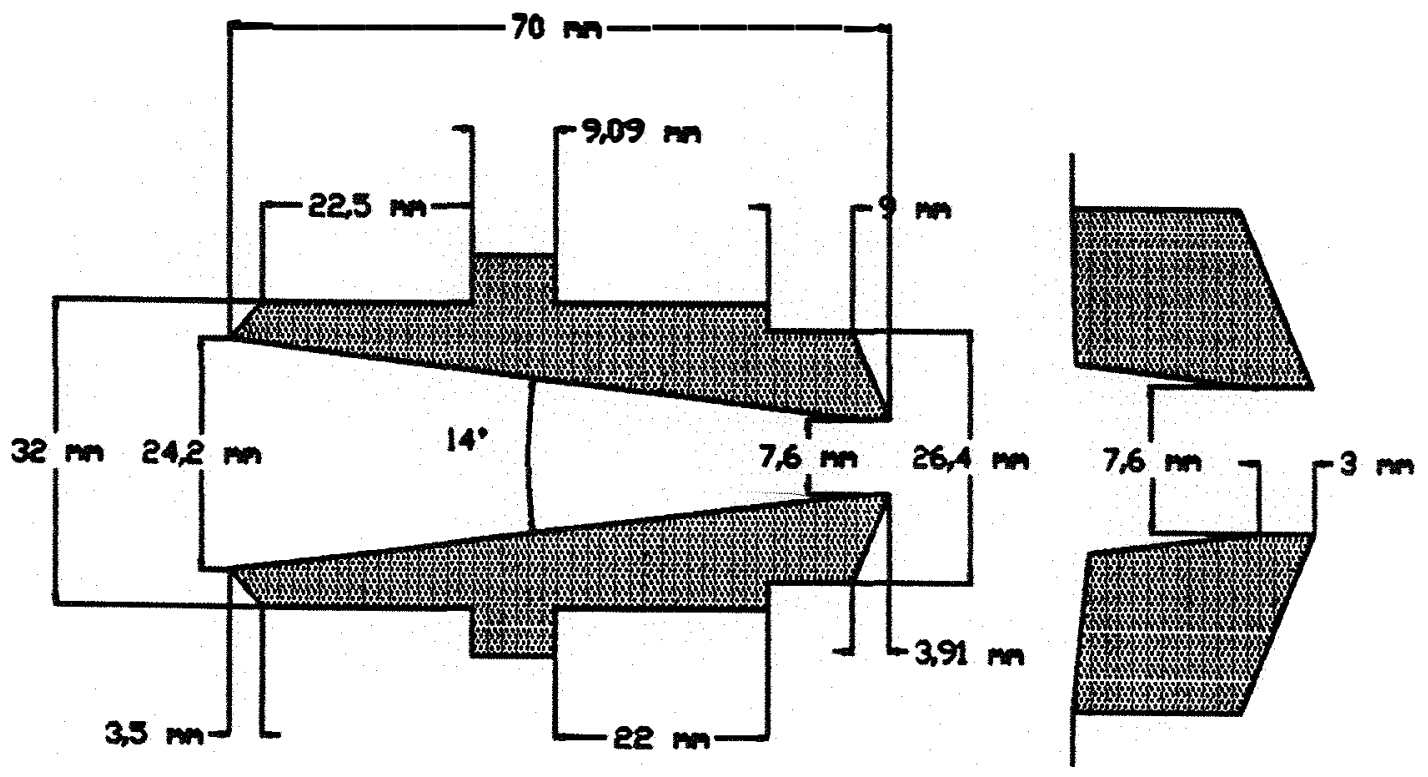

Figura 6 - Bocal convergente do injetor de 1"
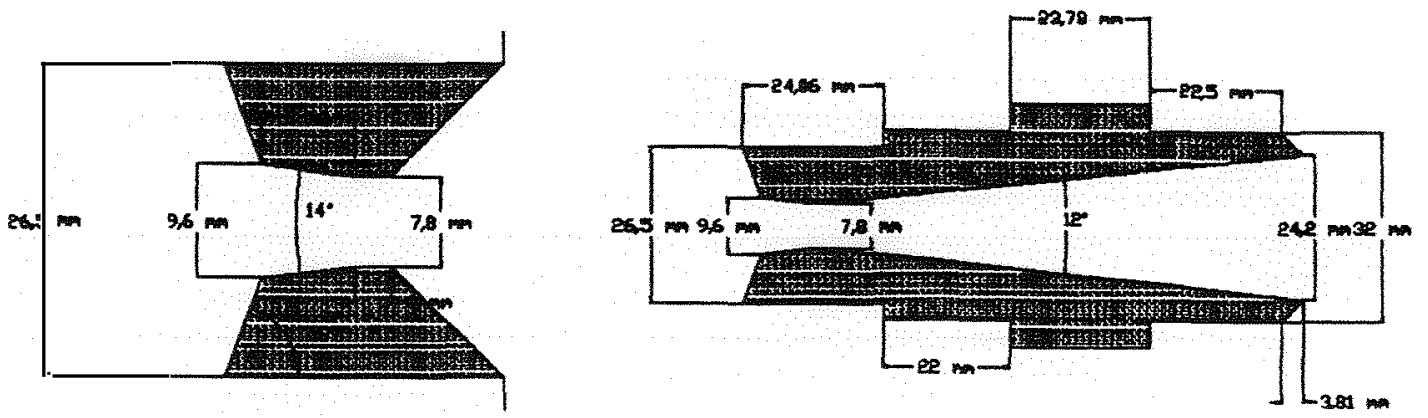

Figura 7 - Bocal divergente do injetor de 1" 


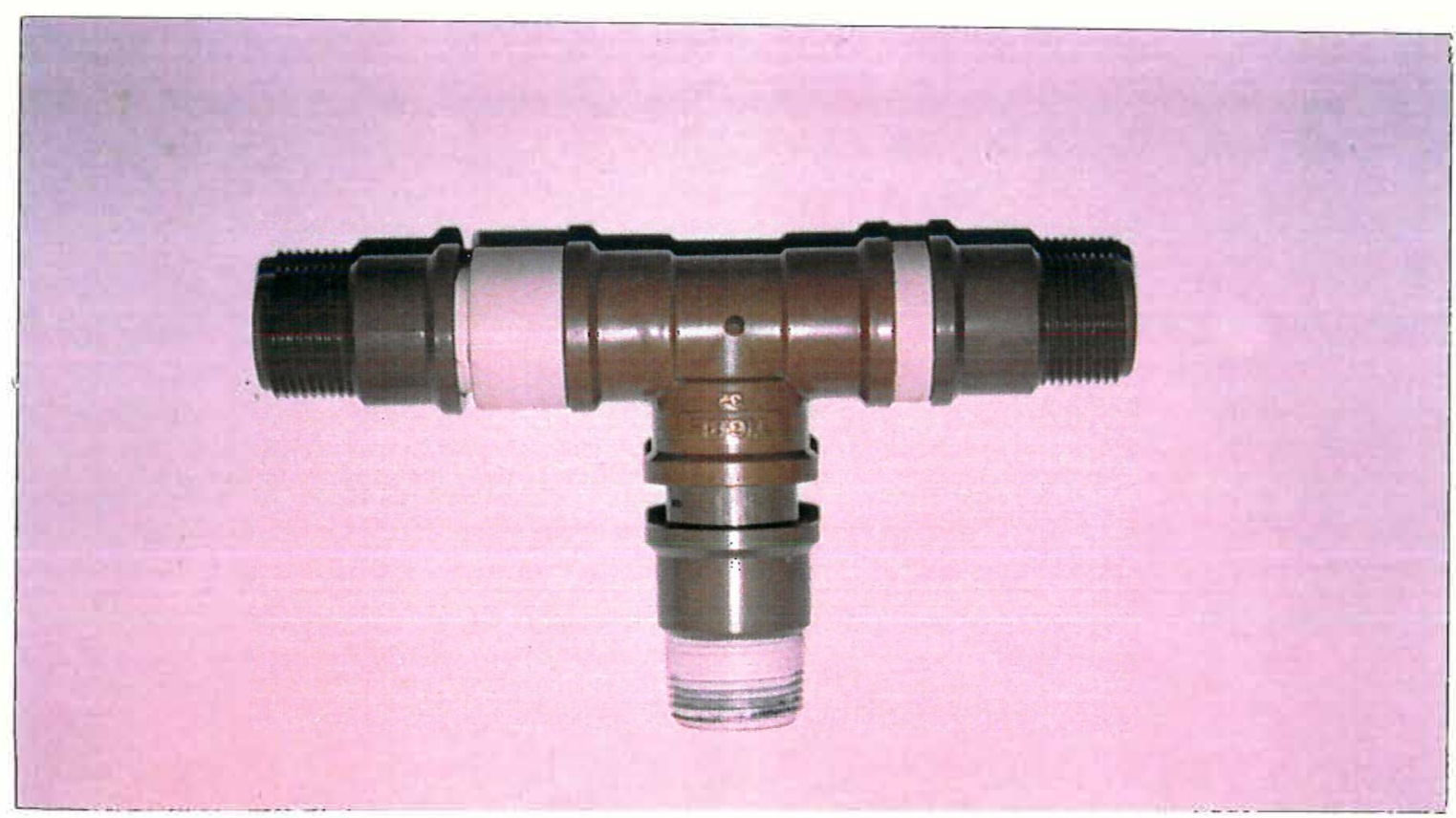

Figura 8 - Vista geral do injetor de 1"

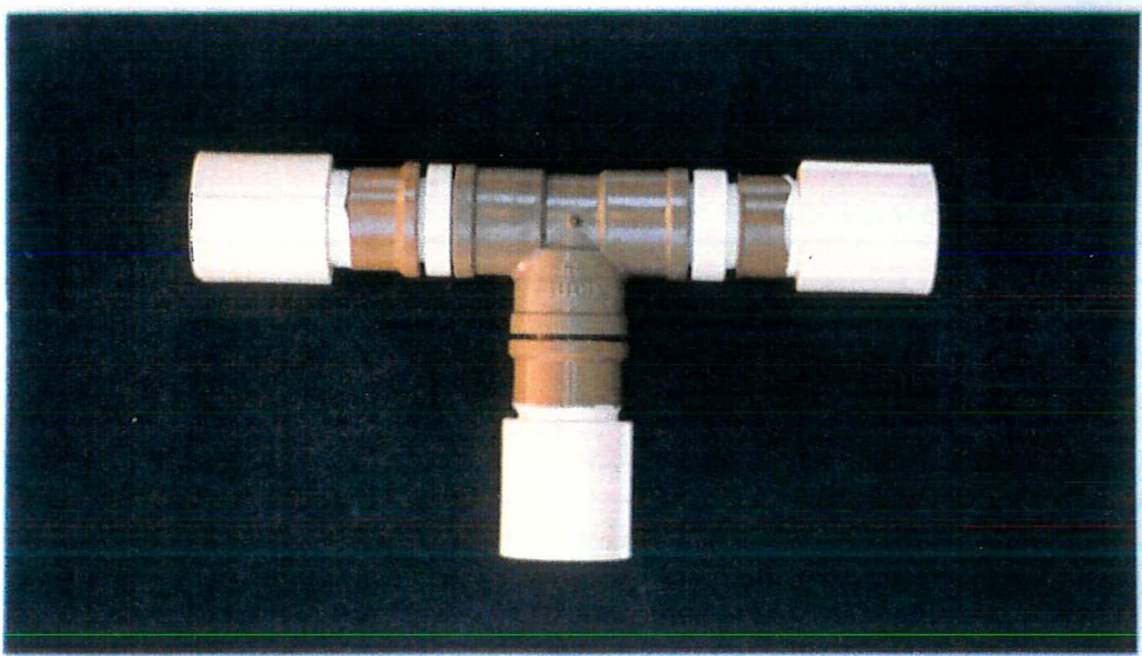

Figura 9 - Vista geral do injetor de 3/4" 


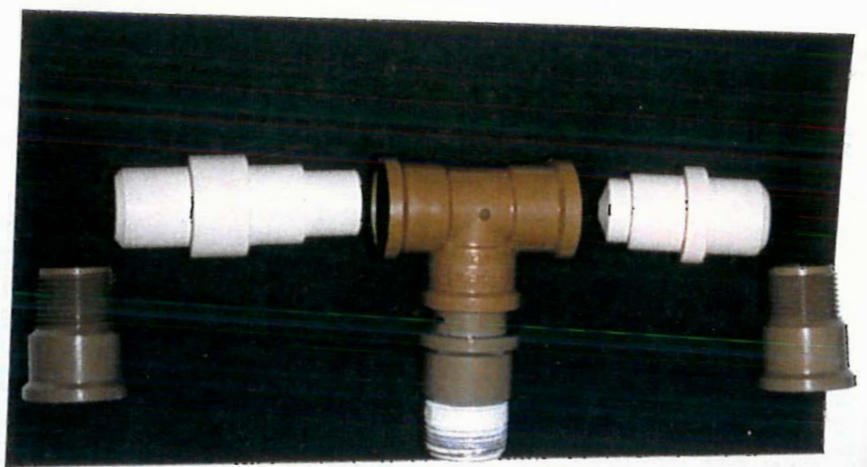

Figura 10 - Vista das partes do injetor de 1"

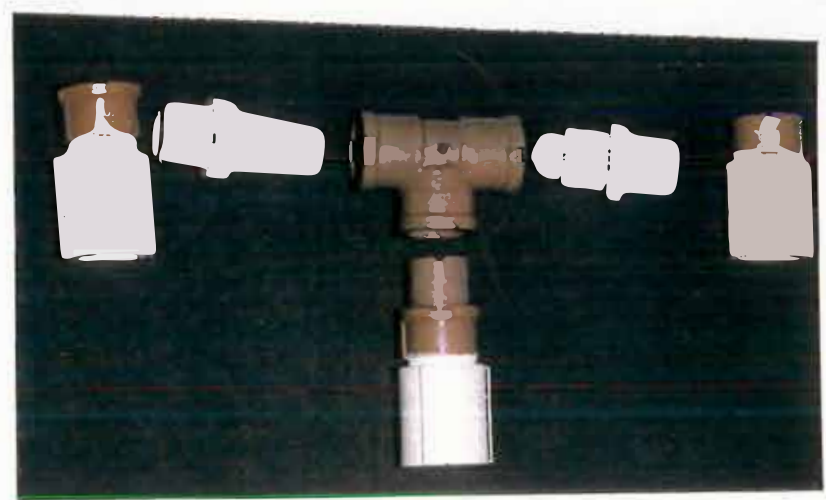

Figura 11 - Vista das partes do injetor de 3/4" 


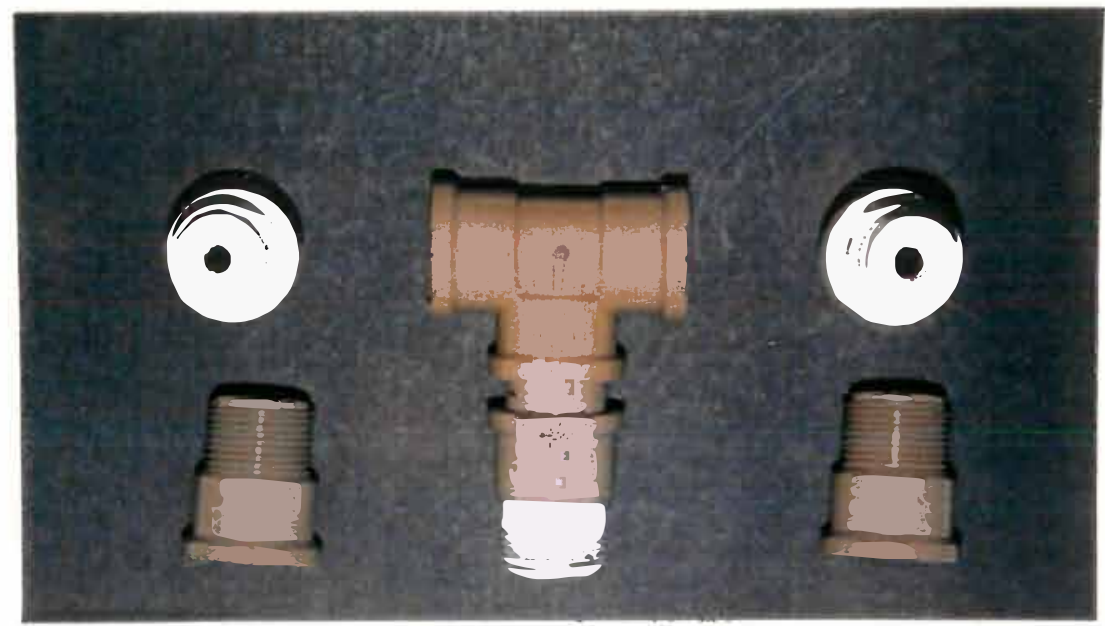

Figura 12 - Vista dos bocais convergente (esquerda), e divergente (direita) do injetor de 1".

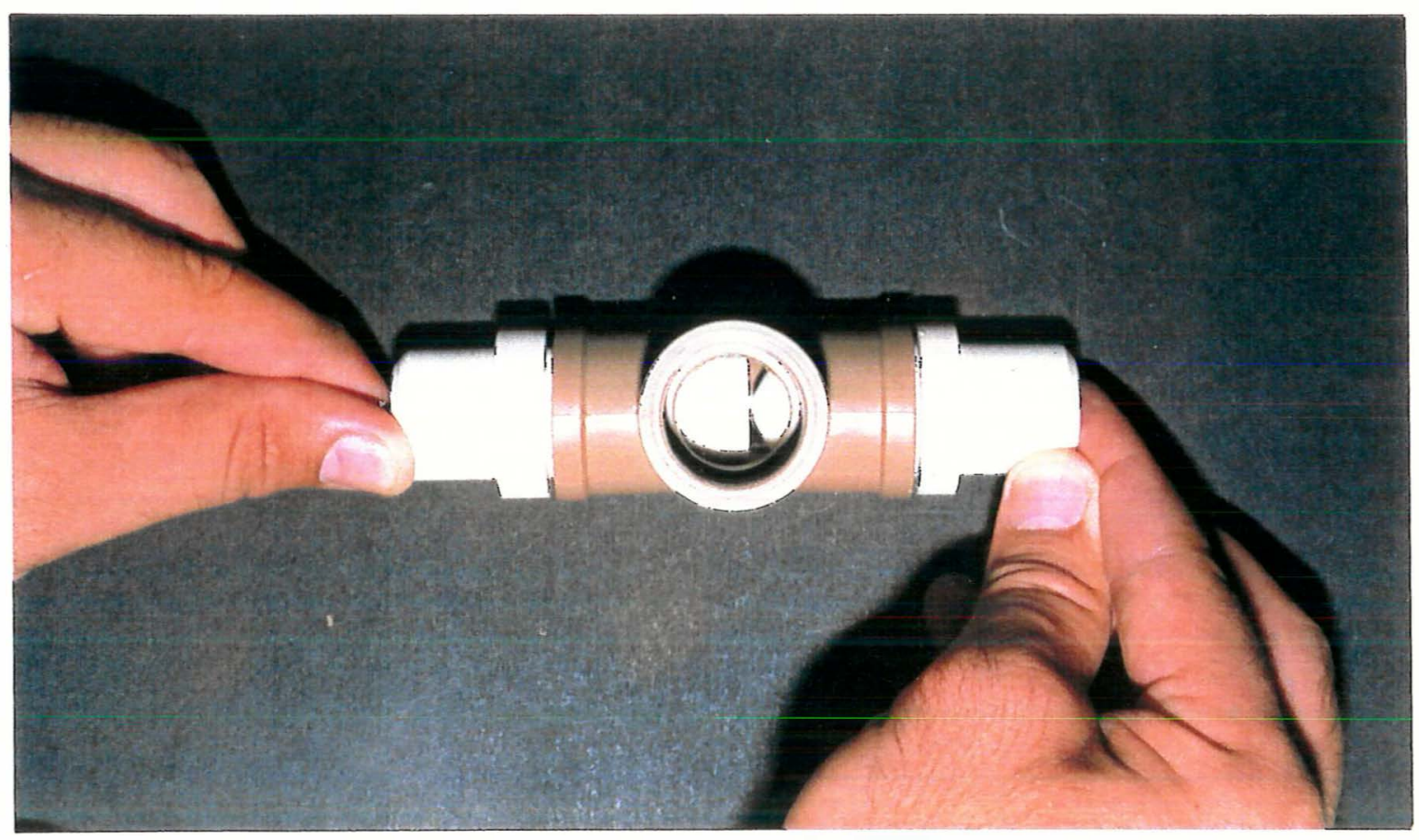

Figura 13 - Vista mostrando o detalhe do interior do injetor de 1". 


\subsection{MÉTODOS}

\subsubsection{Esquemas de montagem dos equipamentos}

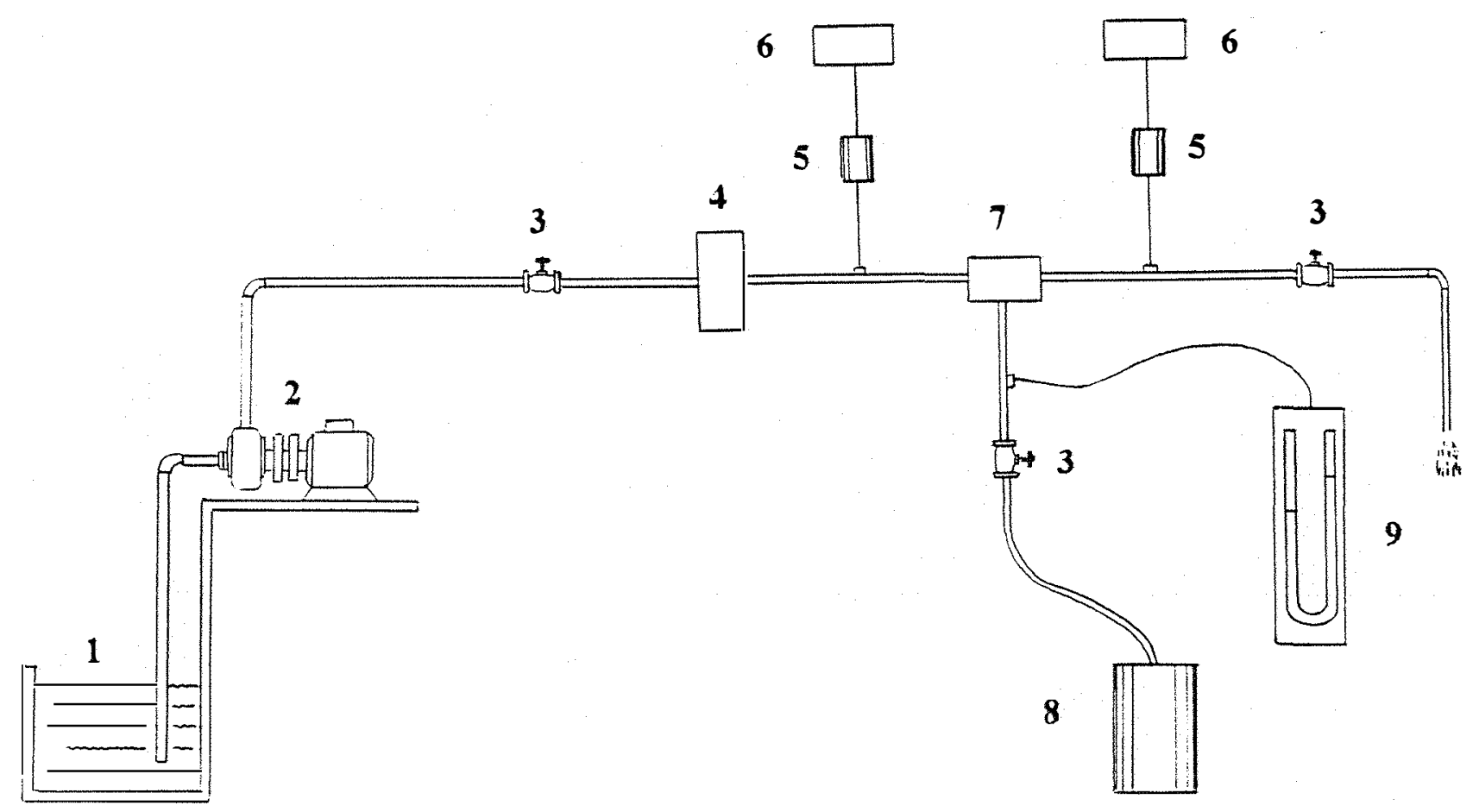

\section{LEGENDA:}

1- Reservatório de água

2- Conjunto moto - bomba

3- Válvula de gaveta

4- Medidor de vazão magnético indutivo

5- Transdutor de pressão
6- Medidor de pressão digital micro processado

7- Injetor Venturi

8- Recipiente com água e mangueira de sucção

9 - Vacuômetro de coluna de mercúrio

Figura 14 - Vista da montagem dos equipamentos. 


\subsubsection{Parâmetros de desempenho}

Foi avaliada a relação entre a vazão de sucção e a tensão de sucção dos dois injetores, sob pressão de alimentação de 20 e 30 m.c.a., e diferencial de pressão de 10 e 15 m.c.a., respectivamente. Com os mesmos parâmetros citados, foi avaliada a razão entre tensão de sucção e rendimento .

Também foram avaliadas as relações entre vazão de sucção e rendimento e diferencial de pressão, para as pressões de alimentação de 10, 15 , $20,25,30,35,40$ m.c.a.

Para o cálculo do rendimento, foi feita uma modificação na expressão apresentada por OLIVEIRA (1993), pois, devido a objetivos diferentes (escorva de bombas centrifugas), os conceitos de energia útil e energia de acionamento foram redefinidos, conforme segue:

$$
E_{u t b l}=E_{3}^{\prime}-E_{2}
$$

e

$$
E_{\text {acionamento }}=E_{1}-E_{3}^{\prime}
$$

então

$$
\eta=\frac{E_{\text {util }}}{E_{\text {acionamento }}}
$$


substituindo-se $E_{\text {uttil }}$ e $E_{\text {acionamento }}$ tem-se,

$$
\eta=\frac{E_{3}^{\prime}-E_{2}}{E_{1}-E_{3}^{\prime \prime}}
$$

e também

$$
\eta=\frac{P_{3} \cdot Q_{3}^{\prime}-P_{2} \cdot Q_{2}}{P_{1} \cdot Q_{1}-P_{3} \cdot Q_{1}}
$$




\section{RESULTADOS E DISCUSSẢO}

De acordo com a metodologia descrita no capitulo anterior, foram feitos os ensaios cujos resultados são apresentados em forma de Tabelas e Figuras, discutidas a seguir.

Nas Figuras 15, 17, 19 e 21 apresentam -se as curvas de vazăo versus tensão de sucção, para os injetores de 1"e 3/4", sob diferentes condições de funcionamento, onde se pode observar a diminuição da vazão de sucção com o aumento da tensão de sucção, para ambos os injetores, com diferenciais de pressão constantes. Ajustou-se o modelo linear, obtendo-se as equações de regressão apresentadas no Quadro 2.

Quadro 2 - Equações de regressão da vazão em função da tensão de sucção.

\begin{tabular}{|c|c|c|c|c|}
\hline Figura & $\begin{array}{l}\text { Pressão de } \\
\text { alimentação } \\
\text { (m.c.a.) }\end{array}$ & $\begin{array}{c}\text { Diferencial } \\
\text { de pressão } \\
\text { (m.c.a.) }\end{array}$ & Equação & $R^{2}$ \\
\hline 15 & 20 & 10 & $Y=64,76251516-38,92721758 X$ & 0,994 \\
\hline 17 & 30 & 15 & $Y=75,58041765-35,6992821 X$ & 0,997 \\
\hline 19 & 20 & 10 & $Y=280,4326727-73,60368409 X$ & 0,999 \\
\hline 21 & 30 & 15 & $Y=387,832863-89,430833491 X$ & 0,996 \\
\hline
\end{tabular}


Quanto à relação entre tensão de sucção e rendimento, mantendo-se constantes os diferenciais de pressão, foram obtidos os gráficos apresentados nas Figuras 16, 18, 20 e 22. Observa-se que o rendimento diminui com o aumento da tensão de sucção. Os diferenciais de pressão testados foram 10 e 15 m.c.a.

As Figuras 23, 25, 27, 29 e 31, correspondem à relação entre vazão de sucção e diferencial de pressão, para o injetor de 3/4", sob pressões de alimentação de $40,35,30,25$, e 20 m.c.a., respectivamente. Observando tais Figuras, percebe-se que existe uma tendência de aumento linear crescente da vazão, com o diferencial de pressão, até certo ponto (diferente para todos). Após tal ponto, a vazão tem uma tendência a estabilizar-se, com o aumento do diferencial de pressão. Os valores do diferencial de pressão, onde se inicia a sucção, têm tendência de se reduzir, com a diminuição da pressão de alimentação.

Procurou-se ajustar equações lineares, para representar a relação entre vazão de suç̧ão e diferencial de pressão, porém apenas no segmento crescente dos gráficos. Os valores de diferencial de pressão, entre os quais foram realizadas as regressões para o injetor de 3/4", são os seguintes: sob pressão de alimentação de 40 m.c.a. (Figura 23) entre 16,61 e 27,33 m.c.a.;sob pressão de alimentação de 35 m.c.a (Figura 25) entre 14,87 e 25,13 m.c.a. ; sob pressão de alimentação de 30 m.c.a.(Figura 27) entre12,90 e 22,92 m.c.a.; sob pressão de alimentação de 25 m.c.a.(Figura 29) entre 10,70 e 18,85 m.c.a. e sob pressão de alimentação de 20 m.c.a. (Figura 31) entre 8,49 e 16,65 m.c.a. Sob pressão de alimentação de 15 m.c.a. e 10 m.c.a. (Figura 33 e 35) manteve-se a relação linear na faixa estudada. 
Os valores das equações de regressão são apresentadas no Quadro 3.

Quadro 3 - Equaçōes de regressão da vazão em função do diferencial de pressão para o injetor de 3/4".

\begin{tabular}{|c|c|c|c|c|c|}
\hline $\begin{array}{l}\text { Figura } \\
\text { correspondente }\end{array}$ & $\begin{array}{c}\text { Pressão de } \\
\text { alimentação } \\
\text { (m.c.a.) }\end{array}$ & Equação & $\mathbf{R}^{2}$ & $\begin{array}{l}\text { Lim } \\
\text { valida } \\
\text { Inf. }\end{array}$ & $\begin{array}{l}\text { es de } \\
\text { e(m.c.a.) } \\
\text { sup. }\end{array}$ \\
\hline 23 & 40 & $Y=-322,752244+19,231027 X$ & 0,999 & 16,61 & 27,33 \\
\hline 25 & 35 & $Y=-308,345846+20,514695 X$ & 0,999 & 14,87 & 25,13 \\
\hline 27 & 30 & $Y=-300,277162+23,012993 X$ & 0,999 & 12,90 & 22,92 \\
\hline 29 & 25 & $Y=-263,510147+24,735118 X$ & 0,999 & 10,70 & 18,85 \\
\hline 31 & 20 & $Y=-244,816505+28,472615 X$ & 0,999 & 8.49 & 16,65 \\
\hline 33 & 15 & $Y=-256,643344+35,658454 X$ & 0,997 & 6,99 & 13,75 \\
\hline 35 & 10 & $Y=-239,761507+49,254002 X$ & 0,995 & 4,79 & 8,51 \\
\hline
\end{tabular}

$X=$ Diferencial de pressão (m.c.a.) $\quad Y=$ Vazão de sucção $(1 / \mathrm{h})$

Nas Figuras $24,26,28,30,32,34$ e 36 , são apresentados os diferenciais de pressão versus rendimento para o injetor de $3 / 4 "$ ", sob pressão de alimentaçăo de 40, 35, 30, 25, 20, 15 e 10 m.c.a., respectivamente. Observa-se que o rendimento aumenta com o aumento do diferencial de pressão, até certo ponto, a partir do qual começa a decrescer, com o aumento do diferencial de pressão.

Com relação ao injetor de 1", obteve-se comportamento igual ao de $3 / 4 "$ ", em relação ao aumento da vazão de sucção, com a elevação do diferencial de pressão, mantendo uma relação linear até um ponto (o qual difere em cada pressão de alimentação), para estabilizar, mesmo elevando o diferencial de pressão. Os valores utilizados para o cálculo das regressões podem ser vistos na Tabela 12, e a validade da equação está entre13,58 e 18,94 m.c.a. de diferencial de pressão para o injetor de 1", submetido a pressão de 
alimentação de 40 m.c.a. Para pressão de alimentação de 35 m.c.a.entre 11,84 e 18,14 m.c.a (Tabela 13), para pressão de alimentação de 30 m.c.a. (Tabela 14) entre 10,34 e 16,40; para pressão de alimentação de 25 m.c.a.(Tabela 15) entre 9,30 e 15,59 m.c.a., e para pressão de alimentação de 20 m.c.a. (Tabela 16) entre 7,10 e 13,15 m.c.a.

Nas Figuras 47 e 49 , observa-se a relação linear entre 0 diferencial de pressão e a vazão de sucção, no injetor de 1", sob pressão de alimentação de 15 m.c.a. e 10 m.c.a.

As equaçōes de regressão encontradas são apresentadas no Quadro 4.

Quadro 4 - Equaç̧̃es de regresão da vazão, em função do diferencial de pressão para o injetor de 1".

\begin{tabular}{|c|c|c|c|c|c|}
\hline $\begin{array}{c}\text { Figura } \\
\text { correspondente }\end{array}$ & $\begin{array}{c}\text { Pressão de } \\
\text { alimentação } \\
\text { (m.c.a.) }\end{array}$ & & Equação & $R^{2}$ & $\begin{array}{c}\text { Limites.de } \\
\text { validade(mca) } \\
\text { Inf. }\end{array}$ \\
\hline 37 & 40 & $Y=-881,0606567+67,14603334 \times$ & 0,992 & 13,58 & 18,94 \\
39 & 35 & $Y=-720,0689512+63,2443512 \times$ & 0,995 & 11,84 & 18,14 \\
41 & 30 & $Y=-12,28512758+1,226705387 \times$ & 0,992 & 10,34 & 16,40 \\
43 & 25 & $Y=-627,3216677+71,40728547 \times$ & 0,994 & 9.30 & 15,59 \\
45 & 20 & $Y=-548,0096826+80,09944011 \times$ & 0,998 & 7,10 & 13,15 \\
47 & 15 & $Y=-649,5230344+101,5305997 \times$ & 0,998 & 6,52 & 12,58 \\
49 & 10 & $Y=-655,6676235+157,8110767 \times$ & 0,998 & 4,09 & 8,05 \\
\hline
\end{tabular}

$$
\mathrm{X}=\text { Diferencial de pressão (m.c.a.) } \quad \mathrm{Y}=\text { Vazão de sucção ( }(\mathrm{h})
$$

Também na relação entre diferencial de pressão e rendimento, o injetor de 1" tem um comportamento similar ao de 3/4": sendo que o rendimento aumenta, com o aumento da pressão, até um ponto quando começa a diminuir, mesmo aumentando o diferencial de pressão (Figuras $38,40,42,44,46,48$ e 50). 
Tabela 1. Tensão de sucção, vazão de sucção, vazão de alimentação e rendimento para o Injetor de 3/4", succionando água, à pressão de alimentação de 20 m.c.a. e diferencial de pressão de 10 m.c.a.

\begin{tabular}{|c|c|c|c|}
\hline $\begin{array}{c}\text { Vazão de } \\
\text { alimentação } \\
(/ / \mathrm{h})\end{array}$ & $\begin{array}{c}\text { Vazão de } \\
\text { sucção } \\
(\mathbf{l} / \mathrm{h})\end{array}$ & $\begin{array}{c}\text { Tensão } \\
\text { de sucção } \\
(\text { m.c.a.) }\end{array}$ & $\begin{array}{c}\text { Rendimento } \\
(\%)\end{array}$ \\
\hline 951,51 & 63,98 & 0,02 & 6,74 \\
957,42 & 57,84 & 0,14 & 6,13 \\
957,42 & 53,71 & 0,28 & 5,77 \\
963,33 & 45,82 & 0,42 & 4.96 \\
975,15 & 41,48 & 0,66 & 4,53 \\
901,06 & 34,26 & 0,81 & 3.78 \\
986,97 & 27,78 & 0,99 & 3.09 \\
992,88 & 22,61 & 1,16 & 2.54 \\
998,79 & 18,00 & 1,23 & 2.02 \\
998,79 & 15,78 & 1,29 & 1.78 \\
1004,70 & 10,90 & 1,33 & 1,23 \\
1016,52 & 0,00 & 1,56 & 0.00 \\
\hline
\end{tabular}

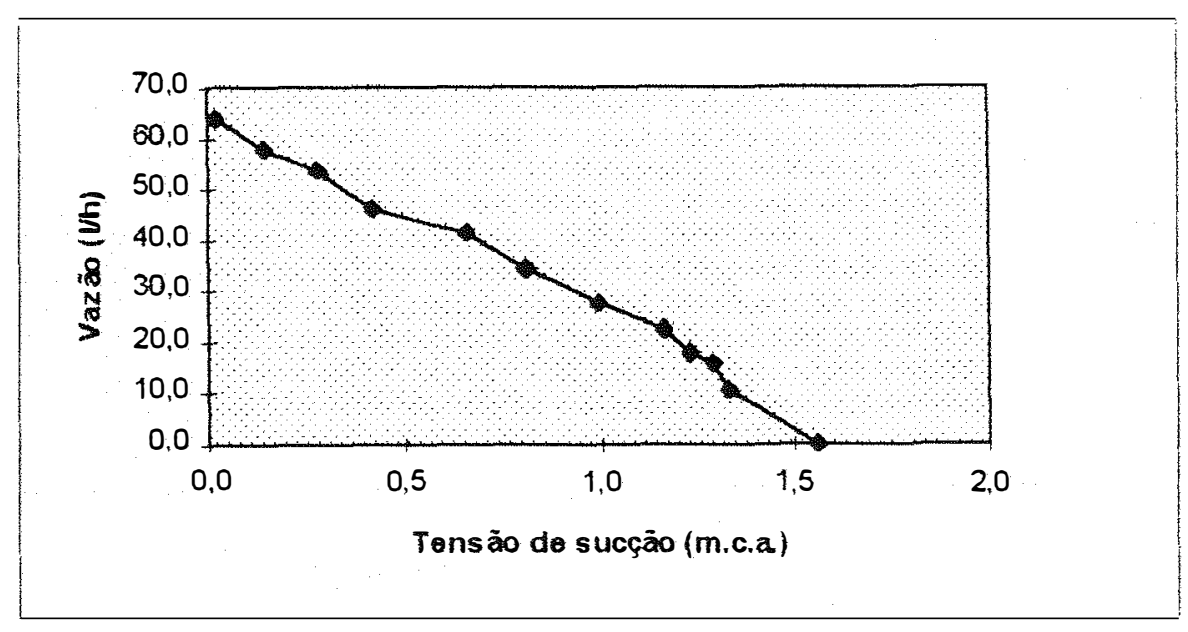

Figura 15. Curva de vazão vs tensão de sucção para o injetor de $3 / 4$ " sob pressão de alimentação de 20 m.c.a. e diferencial de pressão de 10 m.c.a. 


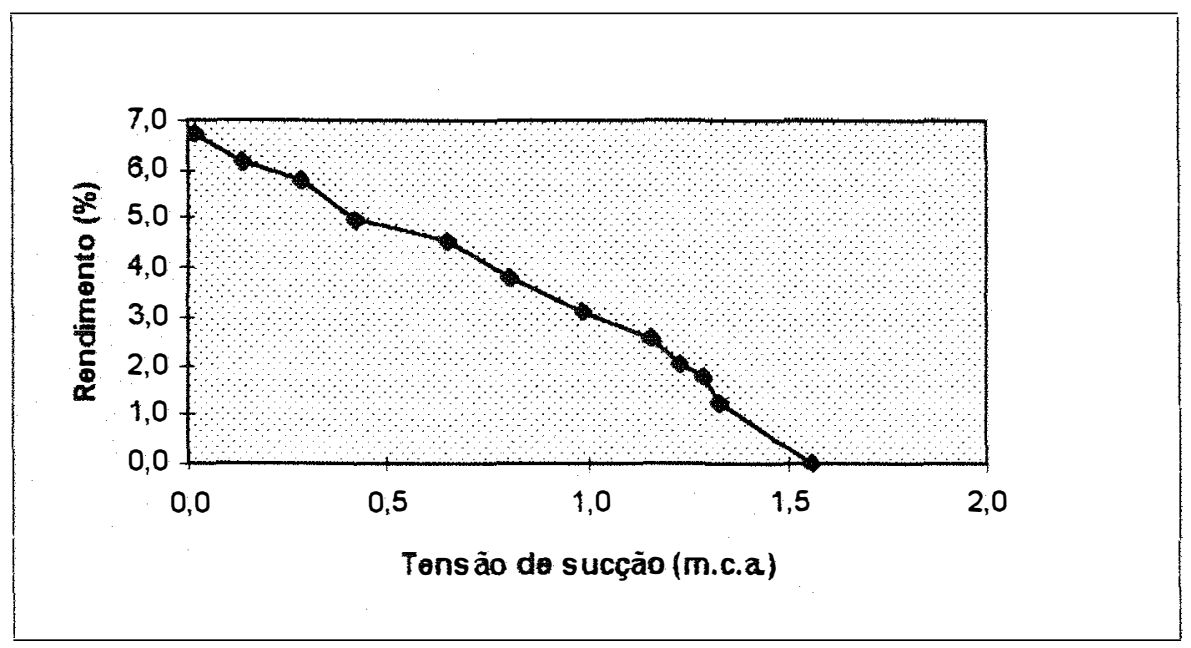

Figura 16. Curva da tensão de sucção vs rendimento do injetor de $3 / 4^{\prime \prime}$ sob pressão de alimentação de 20 m.c.a e diferencial de pressão de 10 m.c.a.

Tabela 2. Tensão de sucção, vazão de sucção, vazão de alimentação e rendimento para o Injetor de $3 / 4 "$, succionando água, à pressão de alimentação de 30 m.c.a., e diferencial de pressão de 15 m.c.a.

\begin{tabular}{|c|c|c|c|}
\hline $\begin{array}{c}\text { Vazão de } \\
\text { alimentação } \\
(\text { //h })\end{array}$ & $\begin{array}{c}\text { Vazão de } \\
\text { sucção } \\
(1 / \mathrm{h})\end{array}$ & $\begin{array}{c}\text { Tensão de } \\
\text { sucção } \\
\text { (m.c.a. })\end{array}$ & $\begin{array}{c}\text { Rendimento } \\
(\%)\end{array}$ \\
\hline 1158,36 & 70,99 & 0,13 & 6,18 \\
1158,36 & 68,65 & 0,27 & 6.03 \\
1170,18 & 60,95 & 0,45 & 5.37 \\
1176,09 & 55,69 & 0,54 & 4.91 \\
1176,09 & 48,27 & 0,71 & 4,30 \\
1187,91 & 39,68 & 0,92 & 3.55 \\
1193,82 & 36,30 & 1,07 & 3,26 \\
1199,73 & 29,72 & 1,27 & 2,69 \\
1199,73 & 25,15 & 1,43 & 2,30 \\
1211,55 & 17,68 & 1,71 & 1,63 \\
1217,46 & 7,03 & 1,91 & 0,65 \\
1229,28 & 0,00 & 2,11 & 0,00 \\
\hline
\end{tabular}




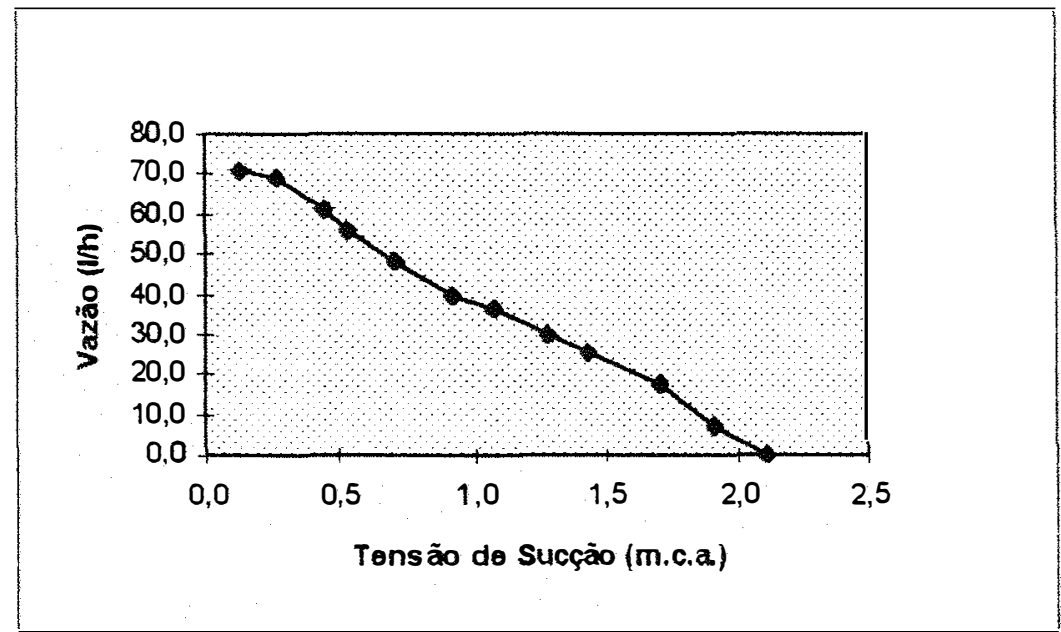

Figura 17. Curva de vazão vs tensão de sucção para o injetor de $3 / 4$ ", sob pressão de alimentação de 30 m.c.a. e diferencial de pressão de 15 m.c.a.

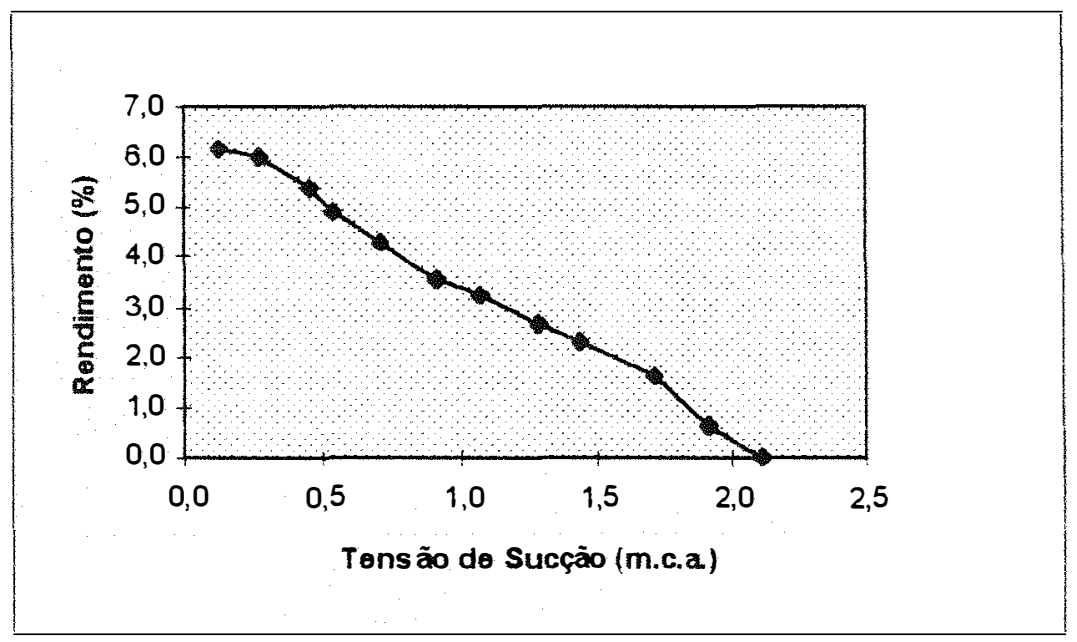

Figura 18. Curva de tensão de sucção vs rendimento do injetor de $3 / 4$ " sob pressão de alimentação de 30 m.c.a. e diferencial de pressão de 15 m.c.a. 
Tabela 3. Tensão de sucção, vazão de sucção, vazão de alimentação e rendimento para o Injetor de 1", succionando água, à pressão de alimentação de 20 m.c.a. e diferencial de pressăo de 10 m.c.a.

\begin{tabular}{|c|c|c|c|}
\hline $\begin{array}{c}\text { Vazão de } \\
\text { alimentação } \\
(\text { I/h) }\end{array}$ & $\begin{array}{c}\text { Vazão de } \\
\text { sucção } \\
(\text { I/h) }\end{array}$ & $\begin{array}{c}\text { Tensão de } \\
\text { sucção } \\
\text { (m.c.a.) }\end{array}$ & $\begin{array}{c}\text { Rendimento } \\
(\%)\end{array}$ \\
\hline 3226,85 & 263,35 & 0,27 & 8,38 \\
3209,13 & 250,07 & 0,45 & 8,14 \\
3274,14 & 239,33 & 0,59 & 7.74 \\
3291,87 & 226,27 & 0,73 & 7,38 \\
3315,51 & 223,81 & 0,82 & 7,30 \\
3333,24 & 212,27 & 0,93 & 6,96 \\
3345,06 & 200,45 & 1,05 & 6,62 \\
3386,43 & 189,40 & 1,25 & 6,29 \\
3410,07 & 170,75 & 1,46 & 5,74 \\
3451,44 & 151,94 & 1,71 & 5,15 \\
3480,99 & 136,90 & 1,87 & 4.66 \\
3516,45 & 120,72 & 2,11 & 4,15 \\
3546,00 & 113,46 & 2,24 & 3,92 \\
3575,55 & 99,81 & 2,42 & 3,47 \\
3593,28 & 85,92 & 2,58 & 3,01 \\
3622,83 & 79,91 & 2,78 & 2,82 \\
3664,20 & 56,75 & 3,10 & 2,03 \\
3705,57 & 35,23 & 3,41 & 1,28 \\
3758,76 & 6,16 & 3,75 & 0,23 \\
3758,76 & 0,00 & 3,79 & 0,00 \\
\hline
\end{tabular}




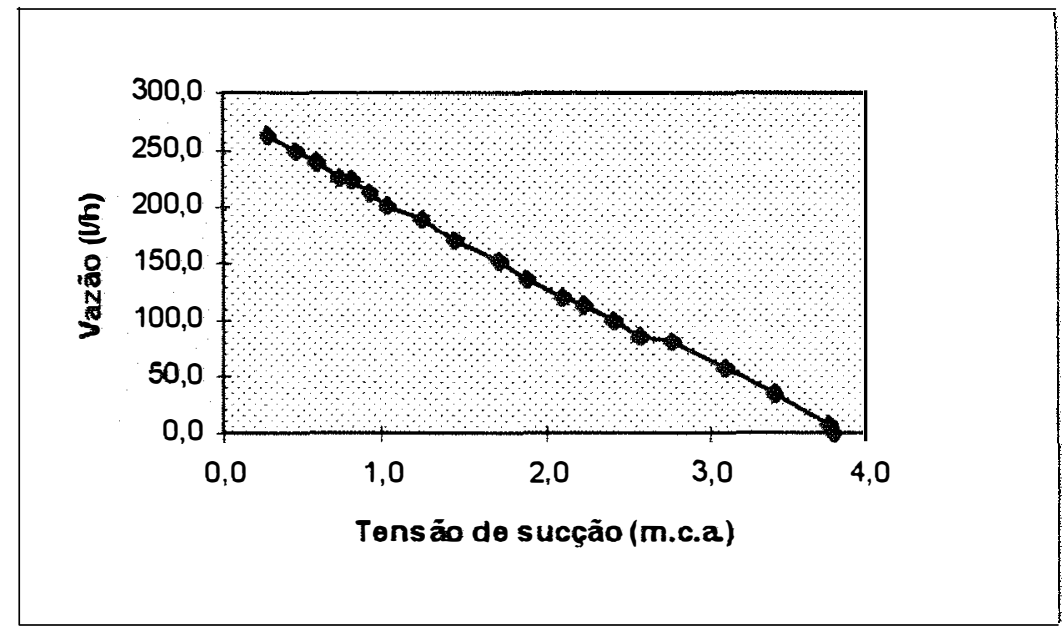

Figura 19. Curva de vazão vs tensão de sucção para o injetor de 1" sob pressão de alimentação de 20 m.c.a. e diferencial de pressão de 10 m.c.a.

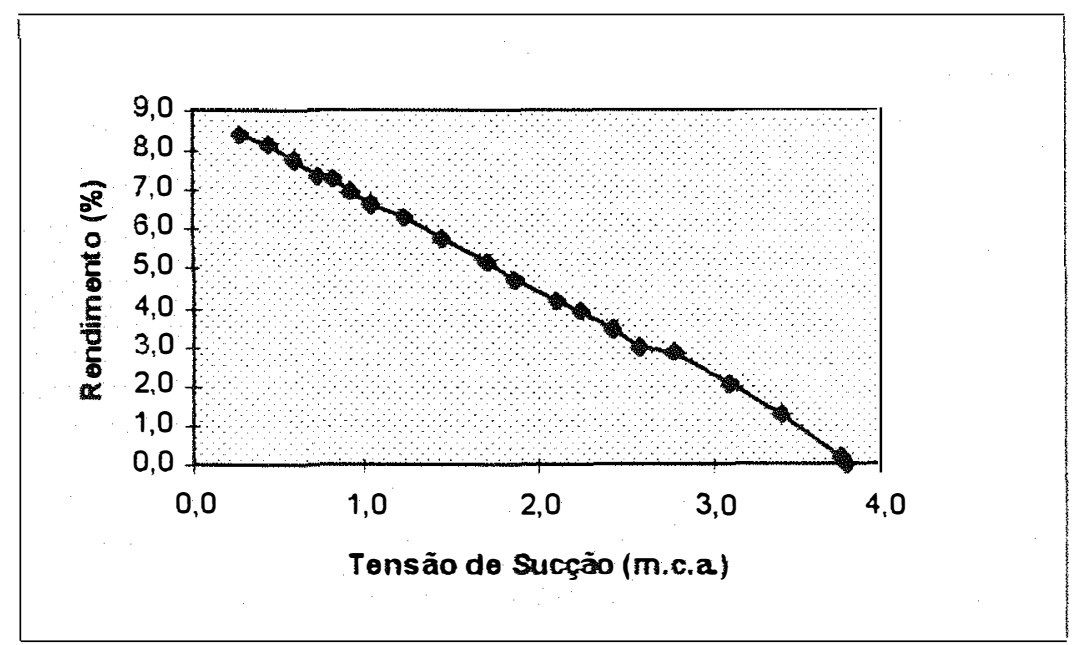

Figura 20. Curva da tensão de sucção vs rendimento do injetor de 1" sob pressão de alimentação de 20 m.c.a., e diferencial de pressão de 10 m.c.a. 
Tabela 4. Tensão de sucção, vazão de sucção, vazão de alimentação, e rendimento para o ejetor de 1", succionando água, à pressão de alimentação de 30 m.c.a., e diferencial de pressão de 15 m.c.a.

\begin{tabular}{|c|c|c|c|}
\hline $\begin{array}{c}\text { Vazão de } \\
\text { alimentação } \\
(1 / \mathrm{h})\end{array}$ & $\begin{array}{c}\text { Vazão de } \\
\text { sucção } \\
(1 / \mathrm{h})\end{array}$ & $\begin{array}{c}\text { Tensão de } \\
\text { sucção } \\
\text { (m.c.a.) }\end{array}$ & $\begin{array}{c}\text { Rendimento } \\
(\%)\end{array}$ \\
\hline 3983,34 & 373,65 & 0,13 & 9,46 \\
3995,16 & 356,85 & 0,27 & 9.09 \\
4001,07 & 342,09 & 0,43 & 8,80 \\
4042,44 & 326,61 & 0,65 & 8,43 \\
4066,08 & 311,53 & 0,82 & 8.08 \\
4101,54 & 286,79 & 1,11 & 7,51 \\
4137,00 & 263,28 & 1,36 & 6.94 \\
4178,37 & 246,74 & 1,70 & 6,57 \\
4213,83 & 224,73 & 1,95 & 6,03 \\
4249,29 & 192,17 & 2,33 & 5,23 \\
4314,30 & 150,59 & 2,78 & 4,14 \\
4379,31 & 107,18 & 3,28 & 2,98 \\
4426,59 & 63,08 & 3,68 & 1,78 \\
4467,96 & 28,79 & 3,92 & 0,81 \\
4479,78 & 0,00 & 4,03 & 0,00 \\
\hline
\end{tabular}




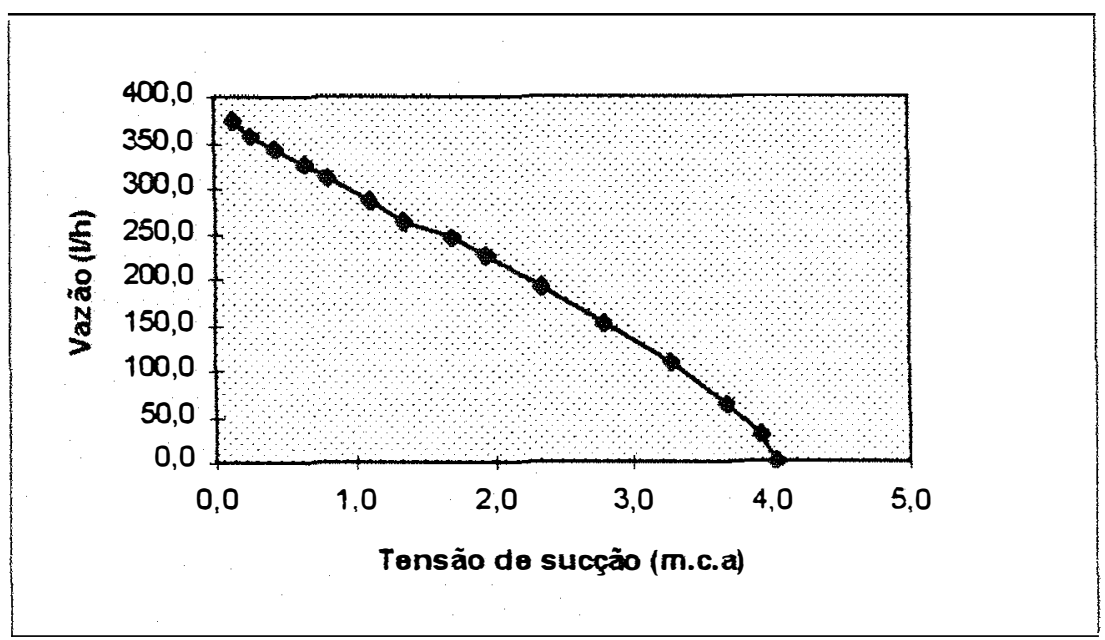

Figura 21. Curva de vazão vs tensão de sucção para o injetor de 1" sob pressão de alimentação de 30 m.c.a. e diferencial de pressão de 15 m.c.a.

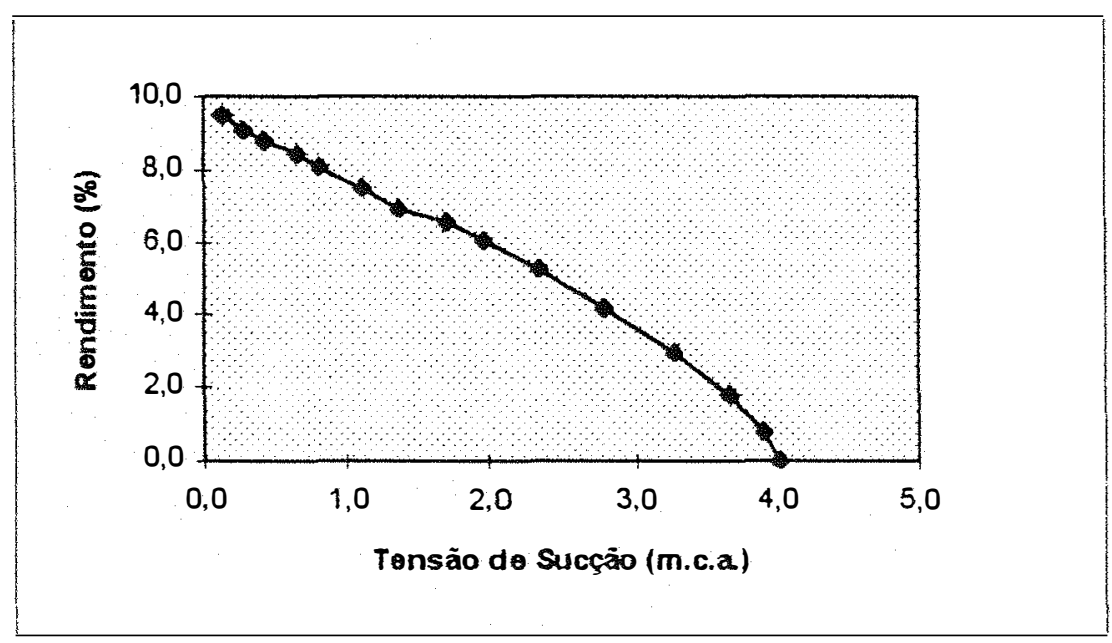

Figura 22. Curva da tensão de sucção vs rendimento do injetor de 1" sob pressão de alimentação de 30 m.c.a. e diferencial de pressão de 15 m.c.a. 
Tabela 5. Pressão à jusante, vazão de sucção, vazão de alimentação e rendimento para o injetor de 3/4", succionando água, à pressão de alimentação de 40 m.c.a. e sob tensão de sucção de 0,5 m.c.a.

\begin{tabular}{|c|c|c|c|c|}
\hline $\begin{array}{c}\text { Vazão de } \\
\text { alimentação } \\
(1 / h)\end{array}$ & $\begin{array}{c}\text { Vazão de } \\
\text { sucção } \\
(\text { (l/h) }\end{array}$ & $\begin{array}{c}\text { Diferencial de } \\
\text { pressão } \\
\text { (m.c.a.) }\end{array}$ & $\begin{array}{c}\text { Pressão } \\
\text { à jusante } \\
\text { (m.c.a) }\end{array}$ & $\begin{array}{c}\text { Rendimento } \\
(\%)\end{array}$ \\
\hline 1359,30 & 220,05 & 38,75 & 1,25 & 0,73 \\
1359,30 & 221,13 & 37,12 & 2,88 & 1,48 \\
1353,39 & 224,79 & 35,48 & 4,52 & 2,35 \\
1353,39 & 224,45 & 33,85 & 6,15 & 3,26 \\
1347,48 & 222,84 & 32,22 & 7,78 & 4,25 \\
1347,48 & 222,48 & 30,59 & 9,41 & 5,35 \\
1347,48 & 219,44 & 28,96 & 11,04 & 6,49 \\
1353,39 & 205,68 & 27,33 & 12,67 & 7,32 \\
1347,48 & 174,47 & 25,70 & 14,30 & 7,46 \\
1347,48 & 139,07 & 24,07 & 15,93 & 7,05 \\
1347,48 & 110,35 & 22,67 & 17,33 & 6.44 \\
1347,48 & 85,89 & 21,50 & 18,50 & 5,63 \\
1347,48 & 65,65 & 20,34 & 19,66 & 4,83 \\
1347,48 & 41,19 & 18,94 & 21,06 & 3.48 \\
1347,48 & 20,58 & 17,78 & 22,22 & 1,95 \\
1347,48 & 6,96 & 17,08 & 22,92 & 0,71 \\
1347,48 & 0,00 & 16,61 & 23,39 & 0,00 \\
\hline
\end{tabular}




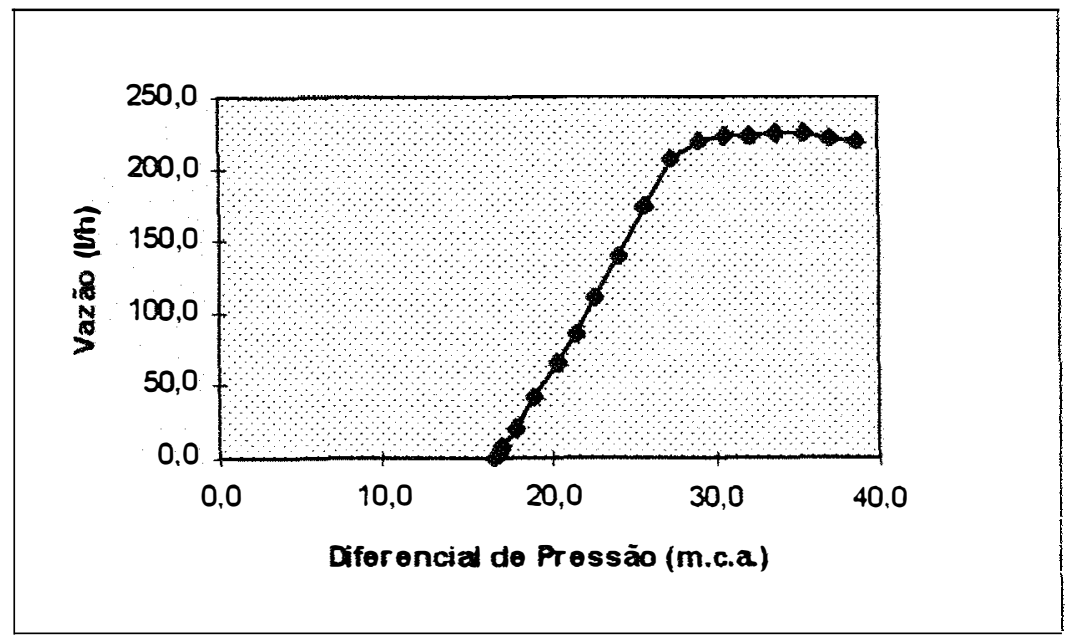

Figura 23. Vazão de sucção vs diferencial de pressão do injetor de 3/4" sob 40 m.c.a.de pressão de alimentação

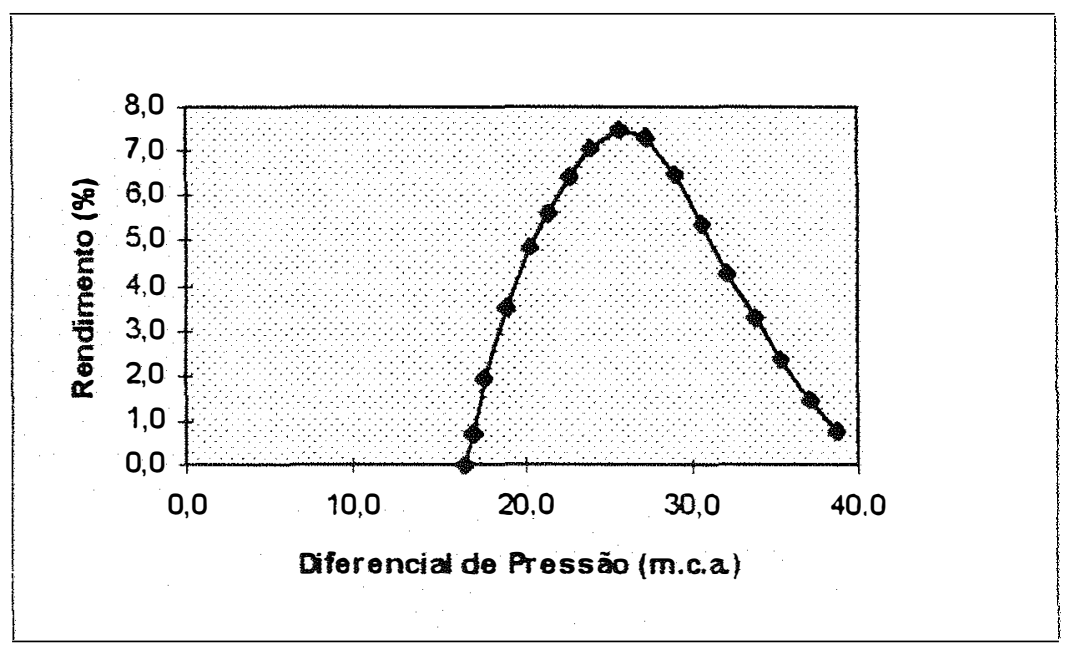

Figura 24. Curva do diferencial de pressão vs rendimento do injetor de 3/4" sob pressão de alimentação de 40 m.c.a. 
Tabela 6. Pressão à jusante, diferencial de pressão, vazão de sucção, vazão de alimentação e rendimento do injetor de 3/4", succionando água, à pressão de alimentação de 35 m.c.a. sob tensão de sucção de 0,5 m.c.a.

\begin{tabular}{|c|c|c|c|c|}
\hline $\begin{array}{c}\text { Vazão de } \\
\text { alimentação } \\
(1 / h)\end{array}$ & $\begin{array}{c}\text { Vazão de } \\
\text { sucção } \\
(1 / h)\end{array}$ & $\begin{array}{c}\text { Diferencial de } \\
\text { pressão } \\
\text { (m.c.a.) }\end{array}$ & $\begin{array}{c}\text { Pressão } \\
\text { à jusante } \\
\text { (m.c.a.) }\end{array}$ & $\begin{array}{c}\text { Rendimento } \\
(\%)\end{array}$ \\
\hline 1270,65 & 220,23 & 33,51 & 1,49 & 1,03 \\
1264,74 & 220,52 & 32,35 & 2,65 & 1,70 \\
1264,74 & 218,98 & 31,18 & 3,82 & 2,40 \\
1264,74 & 220,36 & 30,02 & 4,98 & 3,18 \\
1264,74 & 218,58 & 28,85 & 6,15 & 3,98 \\
1264,74 & 220,29 & 27,69 & 7,31 & 4,91 \\
1264,74 & 215,15 & 26,29 & 8,71 & 5,96 \\
1264,74 & 205,87 & 25,13 & 9,87 & 6,72 \\
1264,74 & 184,81 & 23,96 & 11,04 & 7,04 \\
1258,83 & 163,38 & 23,03 & 11,97 & 7,03 \\
1264,74 & 135,73 & 21,63 & 13,37 & 6,88 \\
1258,83 & 112,19 & 20,47 & 14,53 & 6,54 \\
1264,74 & 87,09 & 19,30 & 15,70 & 5,78 \\
1264,74 & 62,38 & 17,90 & 17,10 & 4,85 \\
1258,83 & 31,11 & 16,74 & 18,26 & 2,77 \\
1258,83 & 8,20 & $15,5$. & 19,43 & 0,83 \\
1252,92 & 0,00 & 14,87 & 20,13 & 0,00 \\
\hline
\end{tabular}




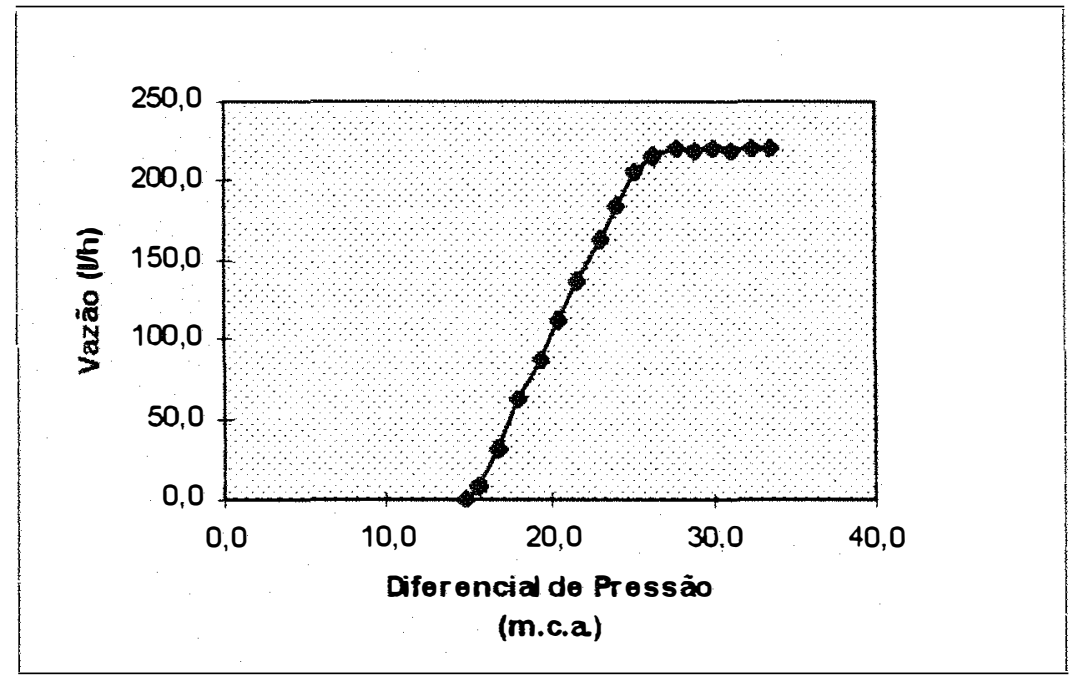

Figura 25. Vazão de sucção vs diferencial de pressão do injetor de 3/4" sob 35 m.c.a. de pressão de alimentação.

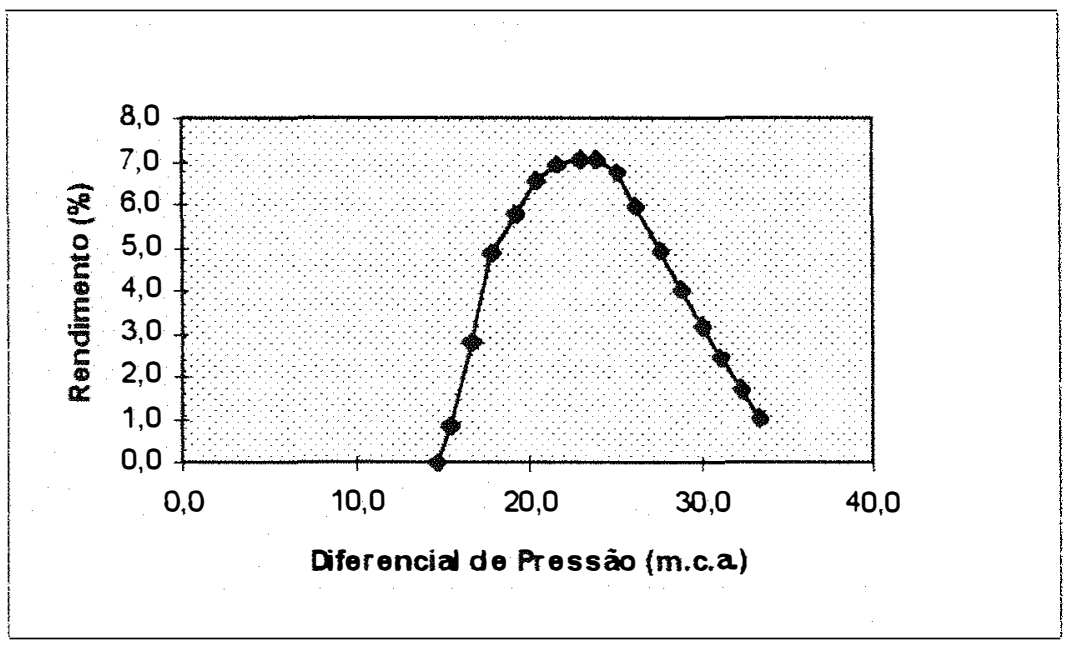

Figura 26. Curva do diferencial de pressão vs rendimento do injetor de $3 / 4 "$ sob pressão de alimentação de 35 m.c.a. 
Tabela 7. Pressão à jusante, diferencial de pressão, vazão de sucção, vazão de alimentação e rendimento do injetor de 3/4", succionando água, à pressão de alimentação de 30 m.c.a. sob tensão de sucção de 0,5 m.c.a.

\begin{tabular}{|c|c|c|c|c|}
\hline $\begin{array}{c}\text { Vazão de } \\
\text { alimentação } \\
(1 / \mathrm{h})\end{array}$ & $\begin{array}{c}\text { Vazão de } \\
\text { sucção } \\
(\mathrm{l} / \mathrm{h})\end{array}$ & $\begin{array}{c}\text { Diferencial de } \\
\text { pressão } \\
\text { (m.c.a.) }\end{array}$ & $\begin{array}{c}\text { Pressão } \\
\text { a jusante } \\
\text { (m.c.a.) }\end{array}$ & $\begin{array}{c}\text { Rendimento } \\
(\%)\end{array}$ \\
\hline 1170,18 & 232,41 & 28,75 & 1,25 & 1,21 \\
1176,09 & 230,35 & 27,81 & 2,19 & 1,90 \\
1176,09 & 233,29 & 26,88 & 3,12 & 2.67 \\
1170,18 & 231,82 & 25,72 & 4,28 & 3,68 \\
1170,18 & 231,70 & 25,02 & 4,98 & 4,34 \\
1170,18 & 230,92 & 24,09 & 5,91 & 5,25 \\
1170,18 & 222,94 & 22,92 & 7,08 & 6,30 \\
1170,18 & 209,28 & 21,99 & 8,01 & 6,92 \\
1170,18 & 179,20 & 20,59 & 9,41 & 7,37 \\
1170,18 & 153,33 & 19,66 & 10,34 & 7.23 \\
1170,18 & 126,49 & 18,73 & 11,27 & 6,79 \\
1164,27 & 109,05 & 17,80 & 12,20 & 6,68 \\
1170,18 & 79,30 & 16,63 & 13,37 & 5,65 \\
1170,18 & 55,65 & 15,47 & 14,53 & 4,62 \\
1170,18 & 27,11 & 14,30 & 15,70 & 2,63 \\
1164,27 & 0,00 & 12,90 & 17,10 & 0,00 \\
\hline
\end{tabular}




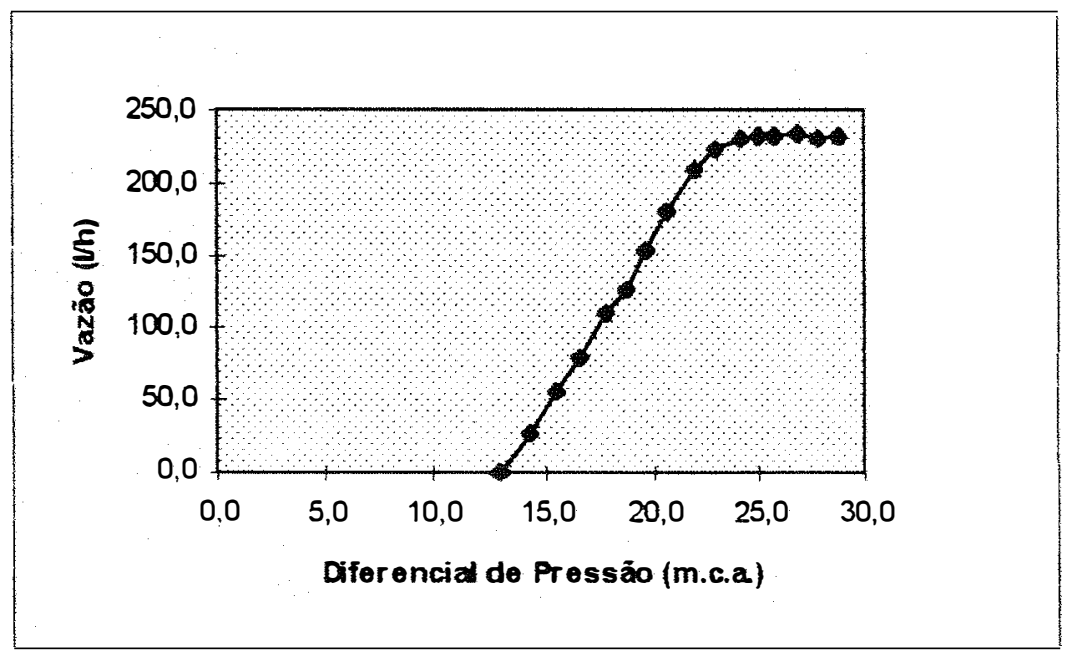

Figura 27. Vazão de sucção vs diferencial de pressão do injetor de 3/4" sob 30 m.c.a. de pressão de alimentação.

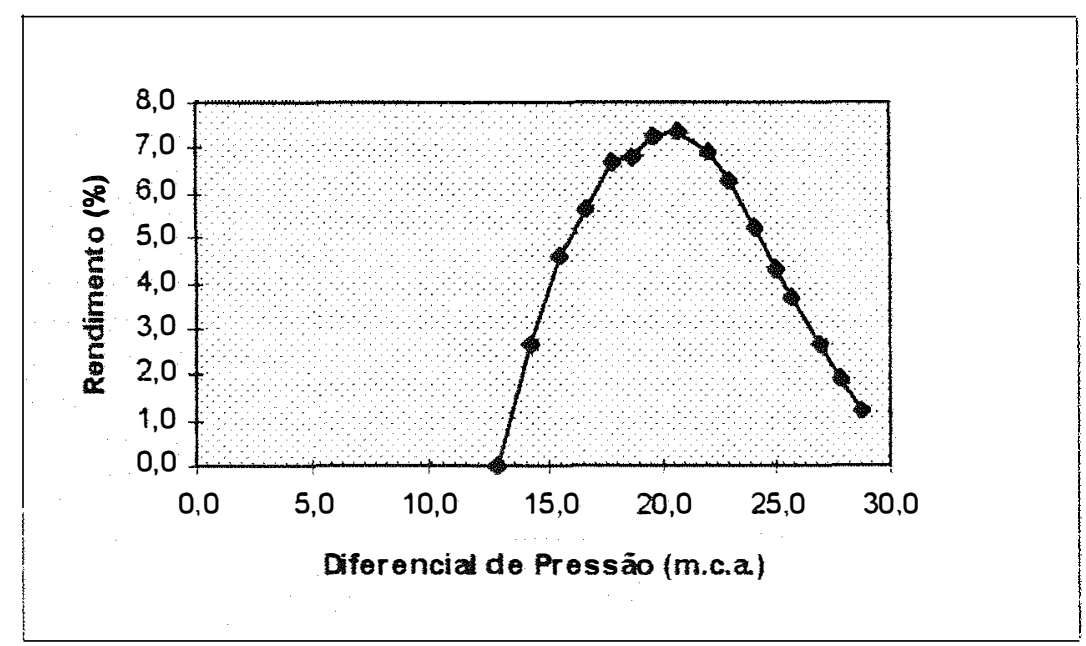

Figura 28. Curva do diferencial de pressão vs rendimento do injetor de $3 / 4^{\prime \prime}$ sob pressão de alimentação de 30 m.c.a. 
Tabela 8. Pressão à jusante, diferencial de pressão, vazão de sucção, vazão de alimentação e rendimento do injetor de $3 / 4^{\prime \prime}$, à pressão de alimentação de 25 m.c.a. sob tensão de sucção de 0,5 m.c.a.

\begin{tabular}{|c|c|c|c|c|}
\hline $\begin{array}{c}\text { Vazão de } \\
\text { alimentação } \\
(1 / h)\end{array}$ & $\begin{array}{c}\text { Vazão de } \\
\text { sucção } \\
(\text { (I/h) }\end{array}$ & $\begin{array}{c}\text { Diferencial de } \\
\text { pressão } \\
\text { (m.c.a.) }\end{array}$ & $\begin{array}{c}\text { Pressão } \\
\text { à jusante } \\
\text { (m.c.a.) }\end{array}$ & $\begin{array}{c}\text { Rendimento } \\
(\%)\end{array}$ \\
\hline 1081,53 & 234,29 & 23,75 & 1,25 & 1,60 \\
1081,53 & 234,46 & 23,05 & 1,95 & 2.30 \\
1081,53 & 229,91 & 21,65 & 3,35 & 3.78 \\
1081,53 & 226,14 & 20,95 & 4,05 & 4.54 \\
1081,53 & 221,77 & 20,25 & 4,75 & 5.32 \\
1075,62 & 217,28 & 19,55 & 5,45 & 6,15 \\
1081,53 & 204,56 & 18,85 & 6,15 & 6.67 \\
1081,53 & 185,02 & 18,15 & 6,85 & 6,93 \\
1075,62 & 170,34 & 17,46 & 7,54 & 7,29 \\
1075,62 & 147,16 & 16,76 & 8,24 & 7,14 \\
1075,62 & 133,89 & 16,06 & 8,94 & 7.32 \\
1075,62 & 110,34 & 15,13 & 9,87 & 7,03 \\
1075,62 & 88,22 & 14,43 & 10,57 & 6.29 \\
1081,53 & 67,47 & 13,49 & 11,51 & 5,55 \\
1075,62 & 50,50 & 12,56 & 12,44 & 4,84 \\
1075,62 & 14,36 & 11,16 & 13,84 & 1.71 \\
1081,53 & 0,00 & 10,70 & 14,30 & 0,00 \\
\hline
\end{tabular}




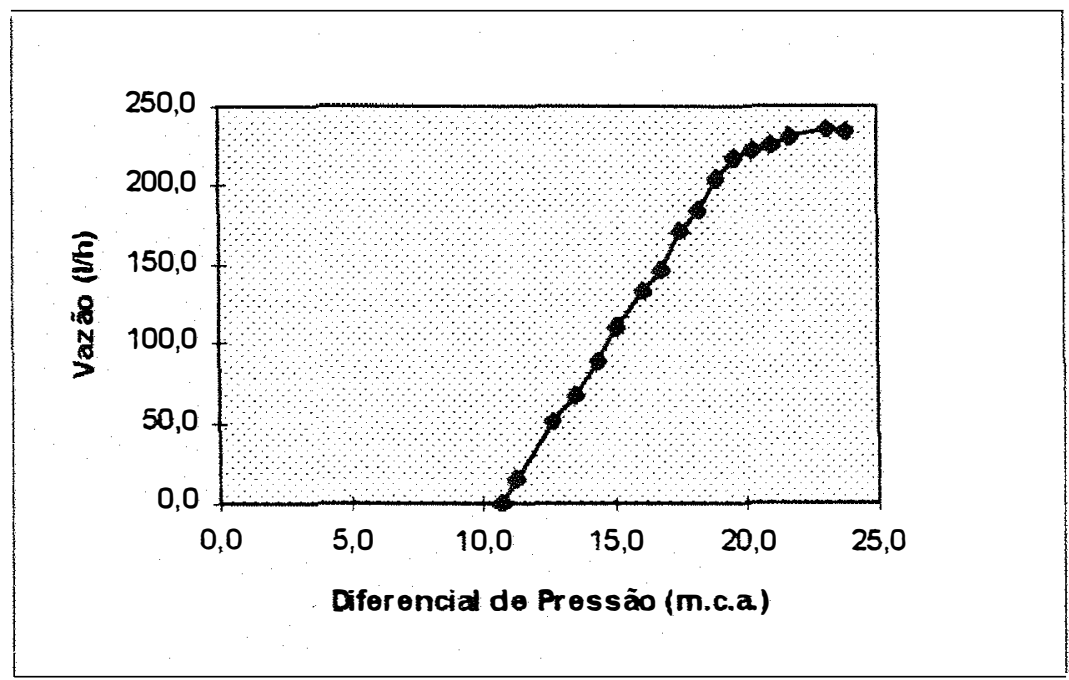

Figura 29. Vazão de sucção vs diferencial de pressão do injetor de 3/4" sob 25 m.c.a. de pressão de alimentação

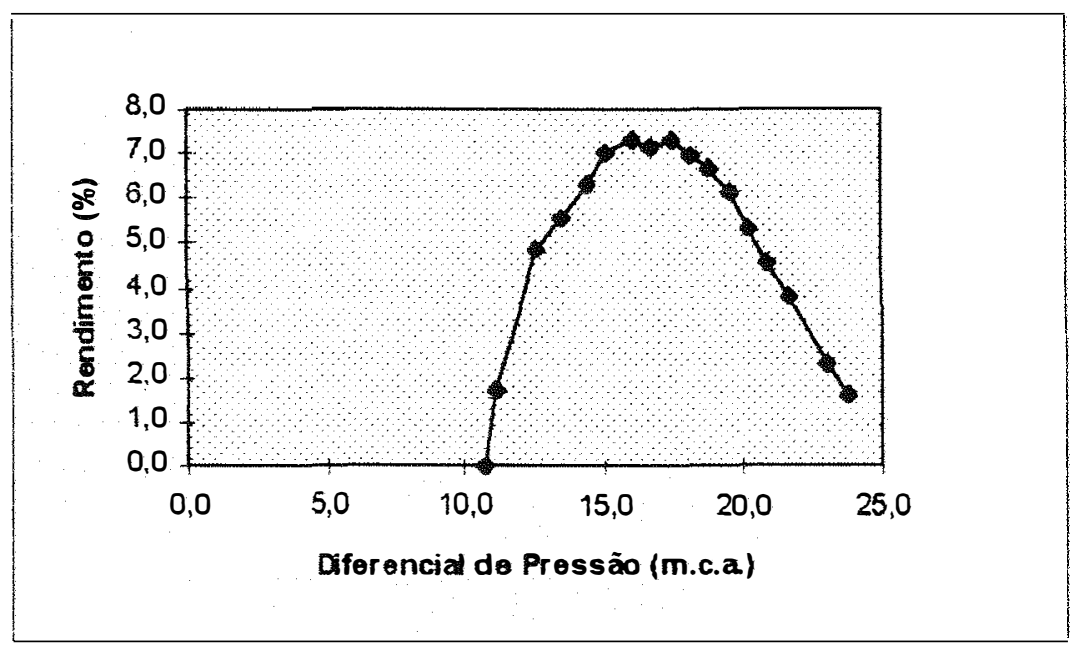

Figura 30. Curva do diferencial de pressão vs rendimento do injetor de 3/4" sob pressão de alimentação de 25 m.c.a. 
Tabela 9. Pressão à jusante, diferencial de pressão, vazão de sucção, vazão de alimentação e rendimento do injetor de 3/4", succionando água, à pressão de alimentação de 10 m.c.a. sob tensão de sucção de 0,5 m.c.a.

\begin{tabular}{|c|c|c|r|c|}
\hline $\begin{array}{c}\text { Vazão de } \\
\text { alimentação } \\
(1 / \mathrm{h})\end{array}$ & $\begin{array}{c}\text { Vazão de } \\
\text { sucção } \\
\text { (I/h) }\end{array}$ & $\begin{array}{c}\text { Diferencial de } \\
\text { pressão } \\
\text { (m.c.a.) }\end{array}$ & $\begin{array}{c}\text { Pressão } \\
\text { à jusante } \\
\text { (m.c.a.) }\end{array}$ & $\begin{array}{c}\text { Rendimento } \\
(\%)\end{array}$ \\
\hline 992,88 & 239,86 & 18,75 & 1,25 & 2,26 \\
986,97 & 239,23 & 18,05 & 1,95 & 3,30 \\
986,97 & 237,90 & 17,35 & 2,65 & 4,38 \\
981,06 & 232,81 & 16,65 & 3,35 & 5,49 \\
986,97 & 205,58 & 15,95 & 4,05 & 5,94 \\
981,06 & 188,66 & 15,25 & 4,75 & 6,62 \\
986,97 & 172,00 & 14,55 & 5,45 & 7.13 \\
981,06 & 151,18 & 13,85 & 6,15 & 7,40 \\
981,06 & 127,72 & 13,15 & 6,85 & 7,28 \\
981,06 & 111,53 & 12,46 & 7,54 & 7,34 \\
981,06 & 85,22 & 11,76 & 8,24 & 6,46 \\
986,97 & 68,55 & 11,06 & 8,94 & 5.93 \\
986,97 & 46,00 & 10,13 & 9,87 & 4,77 \\
981,06 & 28,72 & 9,66 & 10,34 & 3,29 \\
981,06 & 16,25 & 9,19 & 10,81 & 2,04 \\
981,06 & 0,00 & 8,49 & 11,51 & 0,00 \\
\hline
\end{tabular}




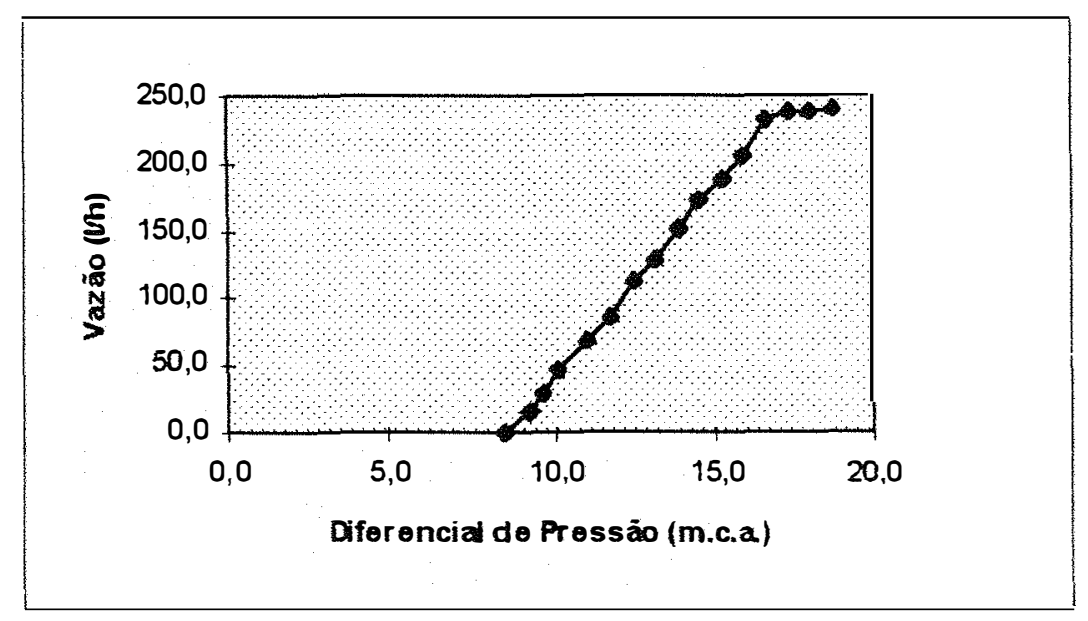

Figura 31. Vazão de sucção vs diferencial de pressão do injetor de 3/4" sob 20 m.c.a. de pressão de alimentação

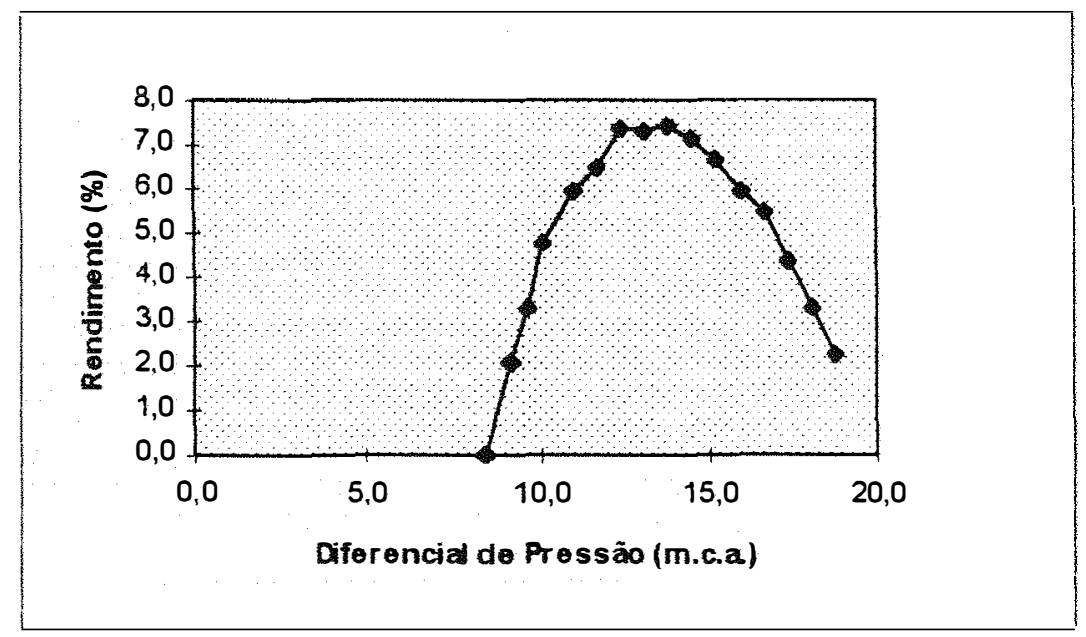

Figura 32. Curva do diferencial de pressão vs rendimento do injetor de $3 / 4 "$ sob pressão de alimentação de 20 m.c.a. 
Tabela 10. Pressão à jusante, diferencial de pressão, vazão de suç̧ão, vazão de alimentação e rendimento do injetor $3 / 4 "$, succionando água, à pressão de alimentação de 15 m.c.a. sob tensão de sucção de 0,5 m.c.a.

\begin{tabular}{|c|c|c|c|c|}
\hline $\begin{array}{c}\text { Vazão de } \\
\text { alimentação } \\
(\text { (I/h) }\end{array}$ & $\begin{array}{c}\text { Vazão de } \\
\text { sucção } \\
(\text { //h) }\end{array}$ & $\begin{array}{c}\text { Diferencial de } \\
\text { pressão } \\
\text { (m.c.a.) }\end{array}$ & $\begin{array}{c}\text { Pressão } \\
\text { a jusante } \\
\text { (m.c.a.) }\end{array}$ & $\begin{array}{c}\text { Rendimento } \\
(\%)\end{array}$ \\
\hline 833,31 & 237,75 & 13,75 & 1,25 & 3,63 \\
833,31 & 227,95 & 13,51 & 1,49 & 4,03 \\
830,36 & 218,67 & 13,28 & 1,72 & 4,40 \\
827,40 & 212,37 & 13,05 & 1,95 & 4,82 \\
827,40 & 205,24 & 12,81 & 2,19 & 5,21 \\
827,40 & 195,67 & 12,58 & 2,42 & 5,49 \\
824,45 & 183,29 & 12,35 & 2,65 & 5,67 \\
827,40 & 177,06 & 12,12 & 2,88 & 5,97 \\
821,49 & 172,24 & 11,88 & 3,12 & 6,39 \\
821,49 & 152,47 & 11,65 & 3,35 & 6,13 \\
818,54 & 142,35 & 11,42 & 3,58 & 6.21 \\
818,54 & 136,56 & 11,18 & 3,82 & 6.45 \\
818,54 & 118,32 & 10,72 & 4,28 & 6,45 \\
818,54 & 100,15 & 10,25 & 4,75 & 6,27 \\
818,54 & 85,01 & 9,79 & 5,21 & 6.06 \\
818,54 & 64,48 & 9,09 & 5,91 & 5.56 \\
821,50 & 38,67 & 8,15 & 6,85 & 4,25 \\
818,54 & 24,39 & 7,69 & 7,31 & 3,03 \\
818,54 & 0,00 & 6,99 & 8,01 & 0,00 \\
\hline
\end{tabular}




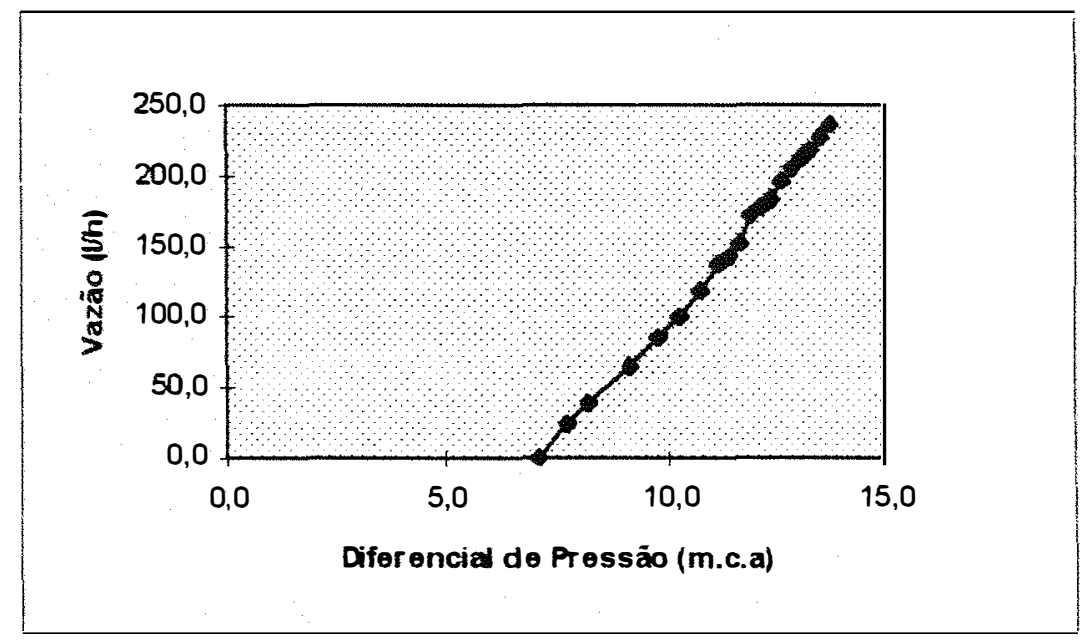

Figura 33. Vazão de sucção vs diferencial de pressão do injetor $3 / 4$ " sob 15 m.c.a. de pressão de alimentação.

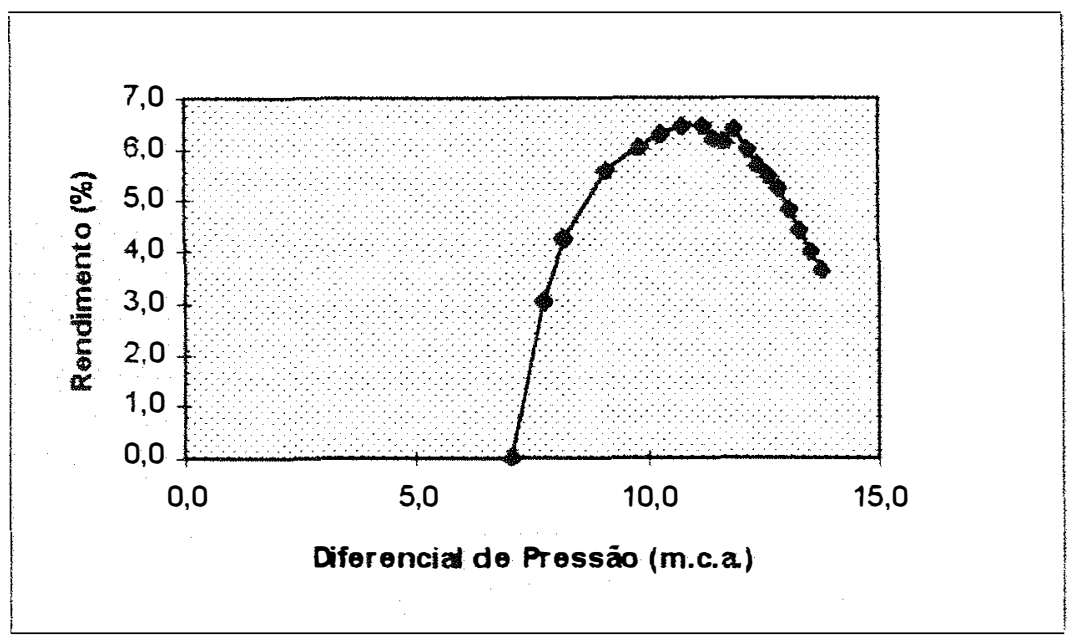

Figura 34. Curva do diferencial de pressão vs rendimento do injetor de $3 / 4^{\prime \prime}$ sob pressão de alimentação de 15 m.c.a. 
Tabela 11. Pressão à jusante, diferencial de pressão, vazão de alimentação e rendimento do injetor de $3 / 4 "$, succionando água, à pressão de alimentação de 10 m.c.a. sob tensão de sucção de 0,5 m.c.a.

\begin{tabular}{|c|c|c|c|c|}
\hline $\begin{array}{c}\text { Vazão de } \\
\text { alimentação } \\
(1 / \mathrm{h})\end{array}$ & $\begin{array}{c}\text { Vazão de } \\
\text { sucção } \\
(1 / \mathrm{h})\end{array}$ & $\begin{array}{c}\text { Diferencial } \\
\text { de pressão } \\
\text { (m.c.a.) }\end{array}$ & $\begin{array}{c}\text { Pressão } \\
\text { à jusante } \\
\text { (m.c.a.) }\end{array}$ & $\begin{array}{c}\text { Rendimento } \\
(\%)\end{array}$ \\
\hline 679,65 & 181,58 & 8,51 & 1,49 & 6,25 \\
679,65 & 170,59 & 8,28 & 1,72 & 6,73 \\
676,70 & 162,92 & 8,05 & 1,95 & 7,33 \\
676,70 & 145,57 & 7,81 & 2,19 & 7,41 \\
676,70 & 133,34 & 7,58 & 2,42 & 7,59 \\
679,65 & 117,47 & 7,12 & 2,88 & 8,21 \\
673,74 & 90,31 & 6,88 & 3,12 & 7,05 \\
673,74 & 80,30 & 6,65 & 3,35 & 6,90 \\
676,70 & 67,16 & 6,42 & 3,58 & 6,31 \\
679,65 & 62,16 & 6,18 & 3,82 & 6,39 \\
670,79 & 44,98 & 5,95 & 4,05 & 5,13 \\
682,61 & 32,25 & 5,48 & 4,52 & 4,33 \\
679,65 & 27,64 & 5,25 & 4,75 & 4,07 \\
682,61 & 10,23 & 5,02 & 4,98 & 1,64 \\
673,74 & 0,00 & 4,79 & 5,21 & 0,00 \\
\hline
\end{tabular}




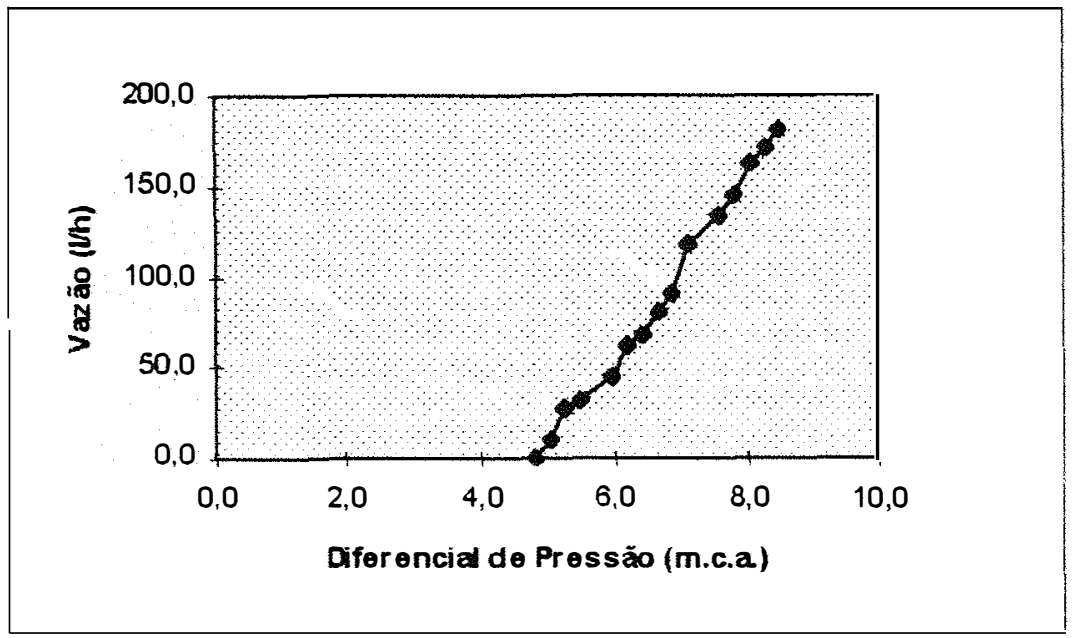

Figura 35. Vazão de sucção vs diferencial de pressão do injetor de $3 / 4$ " sob 10 m.c.a. de pressão de alimentação.

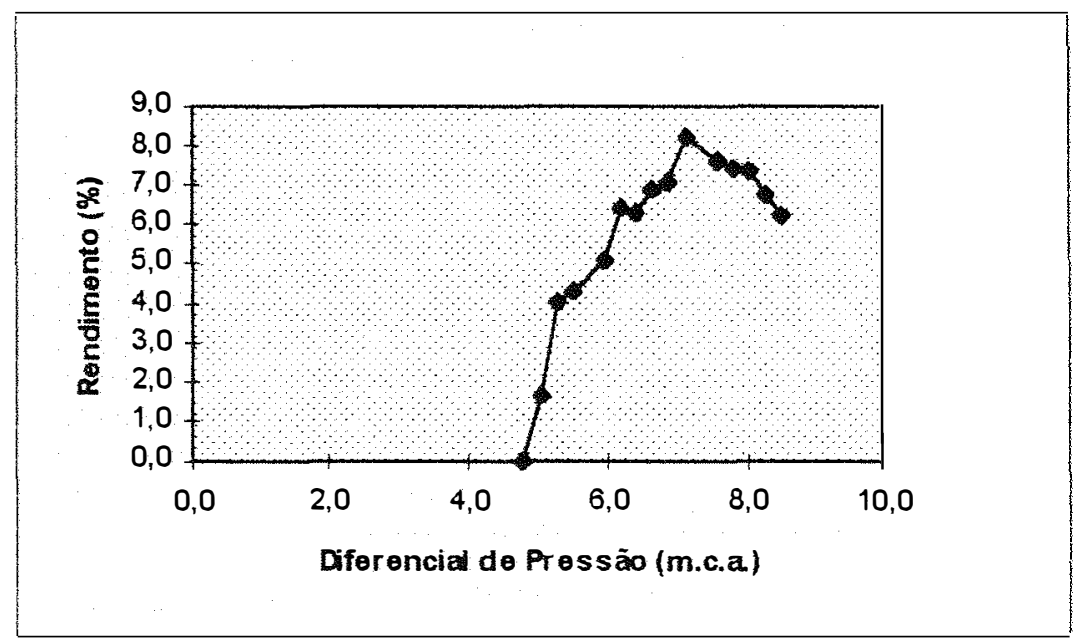

Figura 36. Curva do diferencial de pressão vs rendimento do injetor de $3 / 4 "$ sob pressão de alimentação de 10 m.c.a. 
Tabela 12. Pressão à jusante, diferencial de pressão, vazão de alimentação, e rendimento do injetor de 1", succionando água, à pressão de alimentação de 40 m.c.a. sob tensão de sucção de 0,5 m.c.a.

\begin{tabular}{|c|c|c|c|c|}
\hline $\begin{array}{c}\text { Vazão de } \\
\text { alimentação } \\
(\mathrm{l} / \mathrm{h})\end{array}$ & $\begin{array}{c}\text { Vazão de } \\
\text { sucção } \\
(\text { (//h) }\end{array}$ & $\begin{array}{c}\text { Diferencial } \\
\text { de pressão } \\
\text { (m.c.a.) }\end{array}$ & $\begin{array}{c}\text { Pressão } \\
\text { à jusante } \\
\text { (m.c.a.) }\end{array}$ & $\begin{array}{c}\text { Rendimento } \\
(\%)\end{array}$ \\
\hline 4586,16 & 425,260 & 35,95 & 4,05 & 1,17 \\
4597,98 & 422,470 & 34,55 & 5,45 & 1,58 \\
4597,98 & 421,450 & 33,15 & 6,85 & 2,03 \\
4586,16 & 419,720 & 31,76 & 8,24 & 2,52 \\
4603,89 & 420,91 & 30,36 & 9,64 & 3,05 \\
4597,98 & 417,49 & 28,96 & 11,04 & 3,62 \\
4586,16 & 417,61 & 27,56 & 12,44 & 4,28 \\
4615,71 & 420,99 & 26,16 & 13,84 & 5,00 \\
4603,89 & 416,45 & 24,77 & 15,23 & 5,74 \\
4615,71 & 418,14 & 23,37 & 16,63 & 6,64 \\
4615,71 & 415,42 & 21,97 & 18,03 & 7,59 \\
4615,71 & 412,12 & 21,04 & 18,96 & 8,26 \\
4609,80 & 403,49 & 20,34 & 19,66 & 8,68 \\
4609,80 & 392,38 & 19,64 & 20,36 & 9.04 \\
4603,89 & 374,12 & 18,94 & 21,06 & 9,25 \\
4609,80 & 328,65 & 18,01 & 21,99 & 8,90 \\
4603,89 & 285,70 & 17,31 & 22,69 & 8,31 \\
4603,89 & 243,88 & 16,61 & 23,39 & 7,62 \\
4603,89 & 174,44 & 15,68 & 24,32 & 6.00 \\
4597,98 & 145,37 & 14,98 & 25,02 & 5,39 \\
4597,98 & 87,38 & 14,28 & 25,72 & 3,49 \\
4597,98 & 0,00 & 13,58 & 26,42 & 0,00 \\
\hline
\end{tabular}




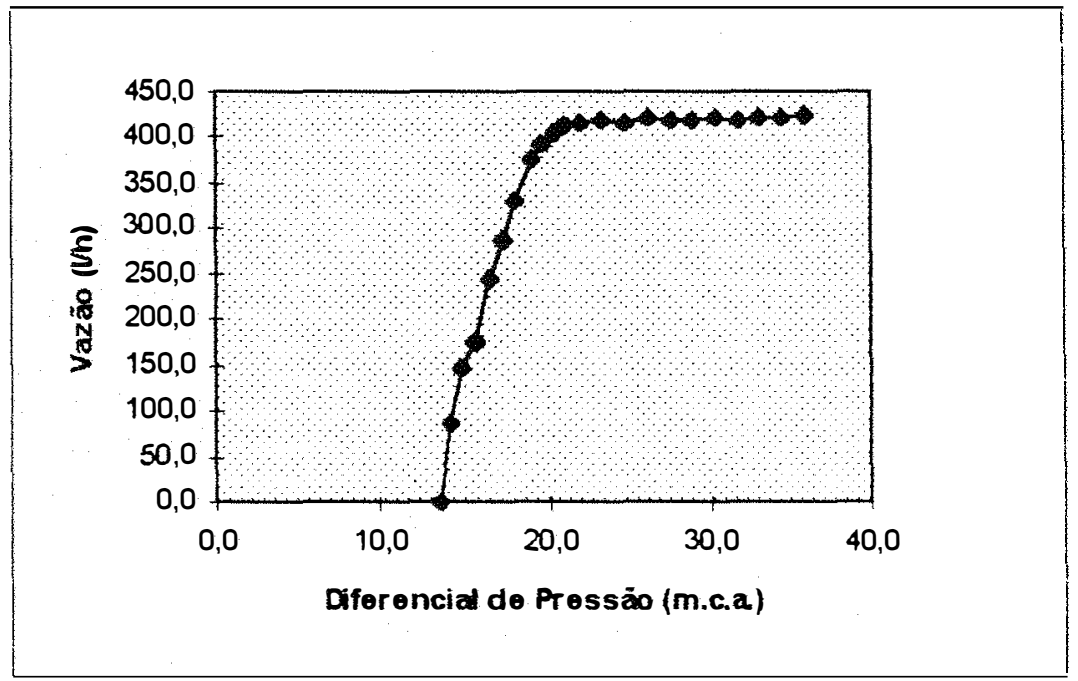

Figura 37. Vazăo de sucção vs diferencial de pressão do injetor de 1" sob 40 m.c.a. de pressão de alimentação.

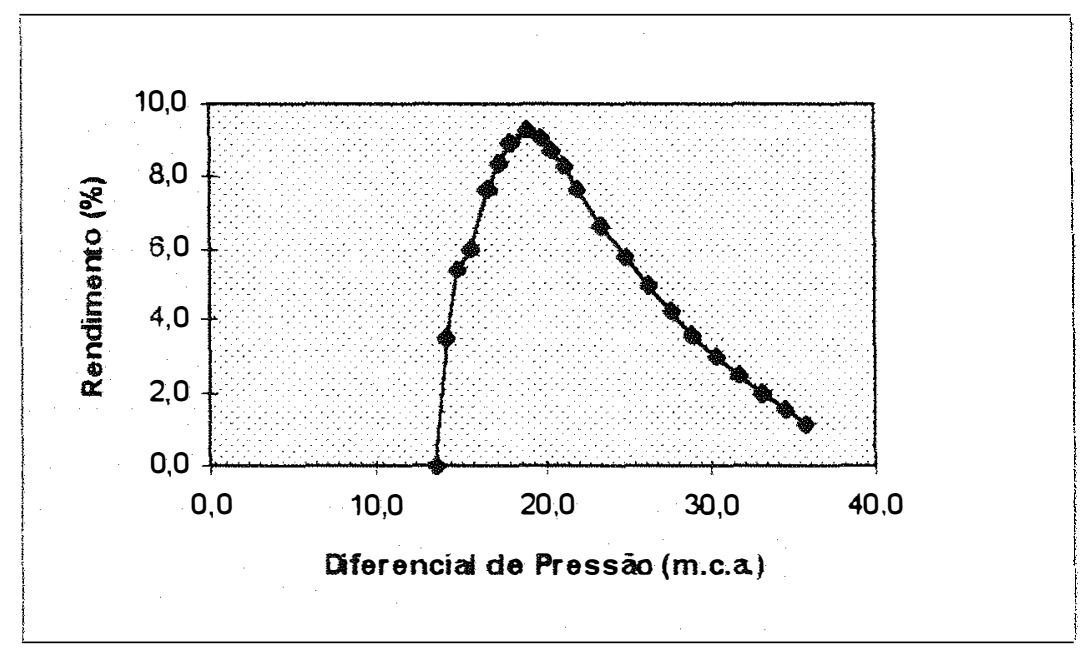

Figura 38. Curva do diferencial de pressão vs rendimento do injetor de 1" sob pressão de alimentação de 40 m.c.a. 
Tabela 13. Pressão à jusante, diferencial de pressão, vazão de alimentação e rendimento do injetor de 1", succionando água, à pressão de alimentação de 35 m.c.a. sob tensão de sução de 0,5 m.c.a.

\begin{tabular}{|c|c|c|r|r|}
\hline $\begin{array}{c}\text { Vazão de } \\
\text { alimentação } \\
(\text { (I/h) }\end{array}$ & $\begin{array}{c}\text { Vazão de } \\
\text { sucção } \\
(1 / h)\end{array}$ & $\begin{array}{c}\text { Diferencial de } \\
\text { pressão } \\
\text { (m.c.a.) }\end{array}$ & $\begin{array}{c}\text { Pressão } \\
\text { a jusante } \\
\text { (m.c.a.) }\end{array}$ & $\begin{array}{c}\text { Rendimento } \\
(\%)\end{array}$ \\
\hline 4314,30 & 440,33 & 31,18 & 3,82 & 1,41 \\
4332,03 & 443,10 & 30,25 & 4,75 & 1,78 \\
4320,21 & 438,64 & 29,32 & 5,68 & 2.14 \\
4326,12 & 440,34 & 28,39 & 6,61 & 2.55 \\
4320,21 & 443,49 & 27,46 & 7,54 & 3,01 \\
4326,12 & 440,05 & 26,52 & 8,48 & 3,44 \\
4326,12 & 439,70 & 25,59 & 9,41 & 3,94 \\
4320,21 & 440,22 & 24,66 & 10,34 & 4,48 \\
4320,21 & 439,10 & 23,26 & 11,74 & 5,35 \\
4255,20 & 437,45 & 21,86 & 13,14 & 6,42 \\
4196,10 & 436,15 & 20,47 & 14,53 & 7,63 \\
4137,00 & 427,90 & 19,07 & 15,93 & 8,91 \\
4196,10 & 412,88 & 18,14 & 16,86 & 9,42 \\
4314,30 & 365,97 & 17,20 & 17,80 & 9,03 \\
4320,21 & 310,06 & 16,27 & 18,73 & 8,48 \\
4320,21 & 261,48 & 15,34 & 19,66 & 7,95 \\
4314,30 & 202,60 & 14,41 & 20,59 & 6,87 \\
4314,30 & 138,87 & 13,48 & 21,520 & 5,26 \\
4314,30 & 113,13 & 13,01 & 21,99 & 4,53 \\
4314,30 & 77,19 & 12,54 & 22,46 & 3,28 \\
4314,30 & 0,00 & 11,84 & 23,16 & 0,00 \\
\hline
\end{tabular}




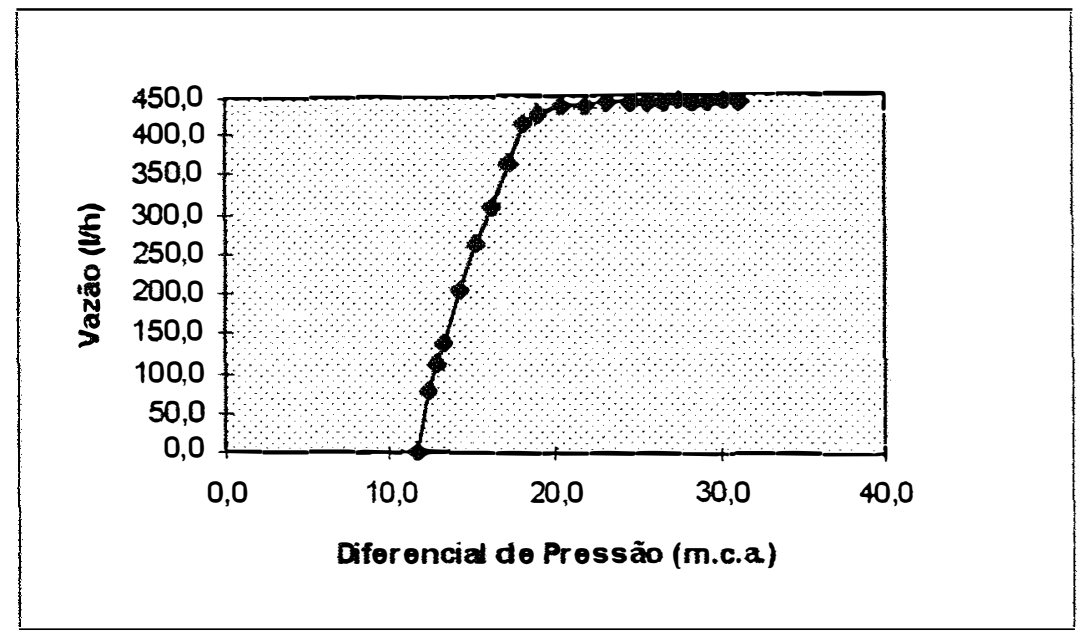

Figura 39. Vazão de sucção vs diferencial de pressão do injetor de 1" sob 35 m.c.a. de pressão de alimentação.

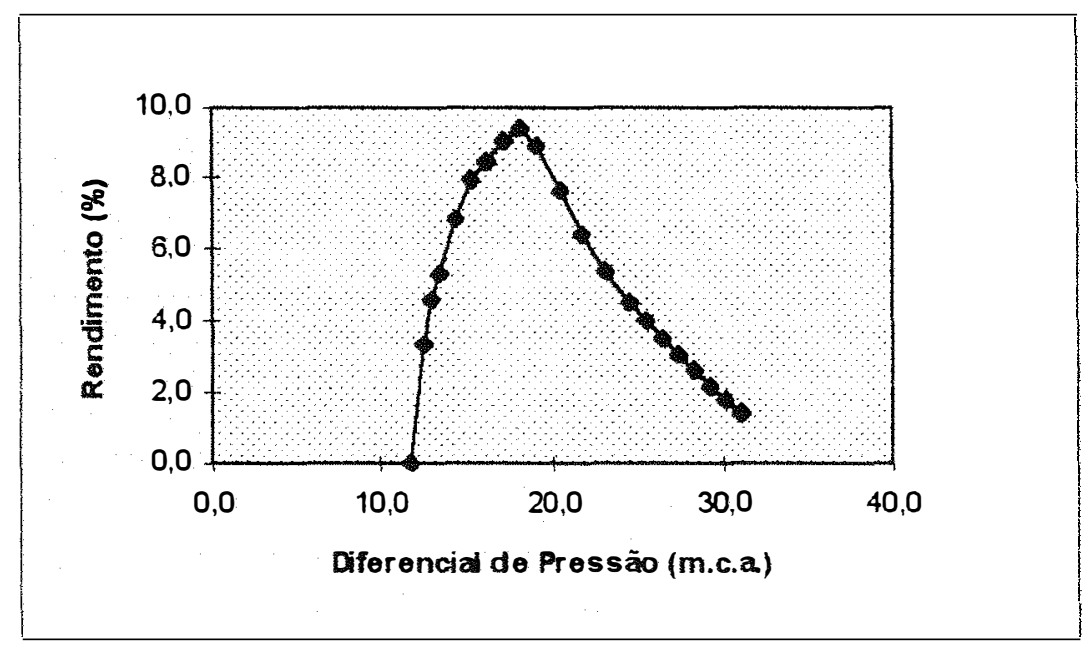

Figura 40. Curva do diferencial de pressão vs rendimento do injetor de 1" sob pressão de alimentação de 35 m.c.a. 
Tabela 14. Pressão à jusante, diferencial de pressão, vazão de sucção, vazăo de alimentação, e rendimento do injetor de 1", succionando água, à pressão de alimentação de 30 m.c.a. sob tensão de sucção de 0,5 m.c.a.

\begin{tabular}{|c|c|c|c|c|}
\hline $\begin{array}{c}\text { Vazão de } \\
\text { alimentação } \\
(\text { I/h) }\end{array}$ & $\begin{array}{c}\text { Vazão de } \\
\text { sucção } \\
\text { (I/h) }\end{array}$ & $\begin{array}{c}\text { Diferencial de } \\
\text { pressão } \\
\text { (m.c.a.) }\end{array}$ & $\begin{array}{c}\text { Pressão } \\
\text { a jusante } \\
\text { (m.c.a.) }\end{array}$ & $\begin{array}{c}\text { Rendimento } \\
(\%)\end{array}$ \\
\hline 4006,98 & 466,54 & 26,65 & 3,35 & 1,68 \\
4001,07 & 467,02 & 25,72 & 4,28 & 2,17 \\
3995,16 & 469,71 & 24,79 & 5,21 & 2.71 \\
3995,16 & 467,74 & 23,85 & 6,15 & 3,26 \\
3995,16 & 467,56 & 22,92 & 7,08 & 3,87 \\
3995,16 & 467,20 & 21,99 & 8,01 & 4,53 \\
3995,16 & 468,34 & 21,06 & 8,94 & 5,26 \\
3989,25 & 466,74 & 20,13 & 9,87 & 6,03 \\
3995,16 & 463,46 & 19,19 & 10,81 & 6,84 \\
3995,16 & 457,30 & 18,26 & 11,74 & 7,67 \\
3989,25 & 452,36 & 17,33 & 12,67 & 8,62 \\
3995,16 & 430,60 & 16,40 & 13,60 & 9,27 \\
3983,34 & 391,46 & 15,47 & 14,53 & 9,55 \\
3995,16 & 329,47 & 14,53 & 15,47 & 9,06 \\
4001,07 & 268,76 & 13,60 & 16,40 & 8,35 \\
3989,25 & 191,44 & 12,67 & 17,33 & 6,75 \\
3989,25 & 121,32 & 11,74 & 18,26 & 4,86 \\
3989,25 & 66,87 & 10,81 & 19,19 & 3.05 \\
3983,34 & 0,00 & 10,34 & 19,66 & 0,00 \\
\hline
\end{tabular}




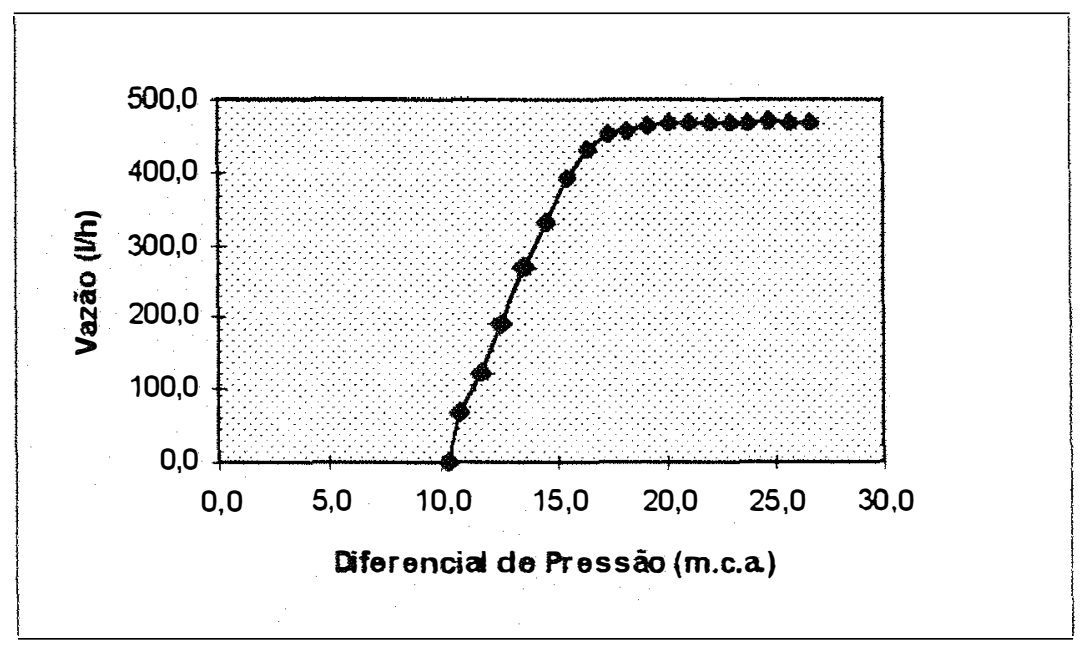

Figura 41. Vazão de suç̧ão vs diferencial de pressão do injetor de 1" sob 30 m.c.a. de pressão de alimentação

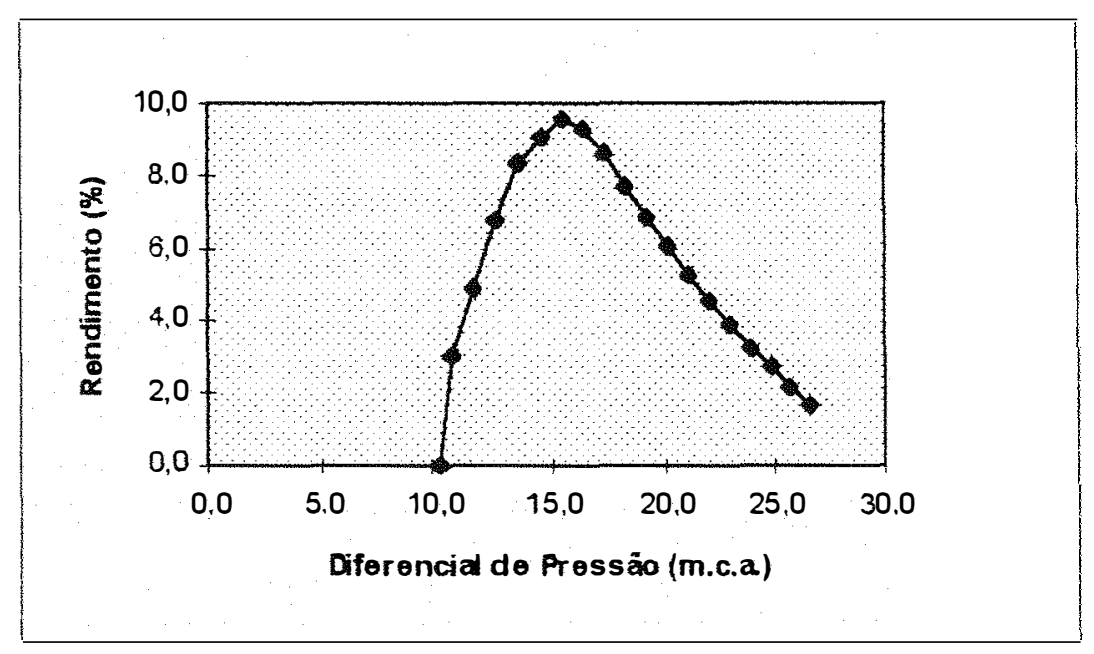

Figura 42. Diferencial de pressão vs rendimento do injetor de 1 " sob pressão de alimentação de 35 m.c.a. 
Tabela 15. Pressão à jusante, diferencial de pressão, vazão de sucção, vazão de alimentação e rendimento do injetor de 1", succionando água, à pressão de alimentação de 25 m.c.a. sob tensão de sucção de 0,5 m.c.a.

\begin{tabular}{|c|c|c|c|c|}
\hline $\begin{array}{c}\text { Vazão de } \\
\text { alimentação } \\
(\mathrm{l} / \mathrm{h})\end{array}$ & $\begin{array}{c}\text { Vazão de } \\
\text { sucção } \\
(1 / h)\end{array}$ & $\begin{array}{c}\text { Diferencial de } \\
\text { pressão } \\
\text { (m.c.a.) }\end{array}$ & $\begin{array}{l}\text { Pressão } \\
\text { à jusante } \\
\text { (m.c.a.) }\end{array}$ & $\begin{array}{c}\text { Rendimento } \\
(\%)\end{array}$ \\
\hline 3676,02 & 500,49 & 22,58 & 2,42 & 1.76 \\
\hline 3676,02 & 495,04 & 21,88 & 3,12 & 2,23 \\
\hline 3664,20 & 500,02 & 21,18 & 3,82 & 2.78 \\
\hline 3658,29 & 495,32 & 20,48 & 4,52 & 3.32 \\
\hline 3658,29 & 498,79 & 19,79 & 5,22 & 3.94 \\
\hline 3664,20 & 494,05 & 19,09 & 5,91 & 4,53 \\
\hline 3658,29 & 492,30 & 18,39 & 6,61 & 5,21 \\
\hline 3658,29 & 489,73 & 17,69 & 7,31 & 5,91 \\
\hline 3664,20 & 483,82 & 16,99 & 8,01 & 6,61 \\
\hline 3652,38 & 488,87 & 16,29 & 8,71 & 7.57 \\
\hline 3658,29 & 469,50 & 15,59 & 9,41 & 8.16 \\
\hline 3658,29 & 433,28 & 14,89 & 10,11 & 8,44 \\
\hline 3652,38 & 385,18 & 14,19 & 10,81 & 8.40 \\
\hline 3646,47 & 338,52 & 13,49 & 11,51 & 8,26 \\
\hline 3640,56 & 304,92 & 12,79 & 12,21 & 8,32 \\
\hline 3646,47 & 240,68 & 12,09 & 12,90 & 7,31 \\
\hline 3640,56 & 192,24 & 11,39 & 13,60 & 6.53 \\
\hline 3646,47 & 145,87 & 10,69 & 14,30 & 5,53 \\
\hline 3634,65 & 103,24 & 10,00 & 15,00 & 4,40 \\
\hline 3664,20 & 0,00 & 9,30 & 15,70 & 0,00 \\
\hline
\end{tabular}




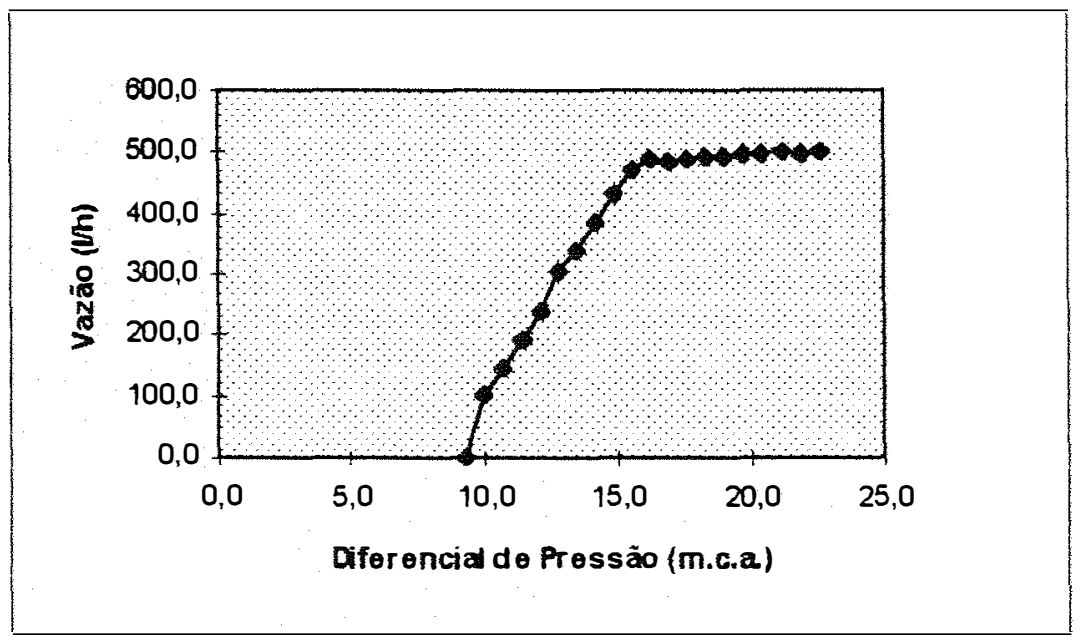

Figura 43. Vazão de sucção vs diferencial de pressão do injetor de 1" sob 25 m.c.a. de pressão de alimentação.

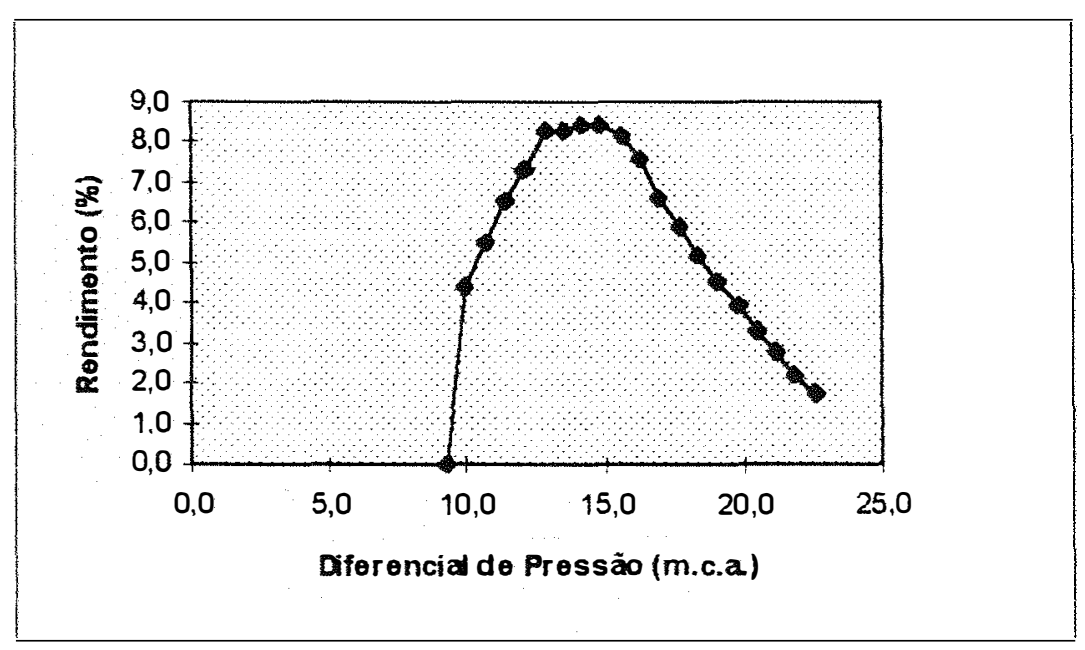

Figura 44. Diferencial de pressão vs rendimento do injetor de 1" sob pressão de alimentação de 25 m.c.a. 
Tabela 16. Pressão à jusante, diferencial de pressão, vazão de sucção, vazão de alimentação e rendimento do injetor de 1", succionando água, à pressão de alimentação de 20 m.c.a. sob tensão de sucção de 0,5 m.c.a.

\begin{tabular}{|c|c|r|r|r|}
\hline $\begin{array}{c}\text { Vazão de } \\
\text { alimentação } \\
(\text { //h) }\end{array}$ & $\begin{array}{c}\text { Vazão de } \\
\text { sucção } \\
\text { (I/h) }\end{array}$ & $\begin{array}{c}\text { Diferencial de } \\
\text { pressão } \\
\text { (m.c.a.) }\end{array}$ & $\begin{array}{r}\text { Pressão } \\
\text { à jusante } \\
\text { (m.c.a.) }\end{array}$ & $\begin{array}{c}\text { Rendimento } \\
(\%)\end{array}$ \\
\hline 3268,23 & 544,97 & 17,35 & 2,65 & 3,03 \\
3274,14 & 538,37 & 15,95 & 4,05 & 4,69 \\
3280,05 & 532,71 & 15,25 & 4,75 & 5,59 \\
3280,05 & 532,99 & 14,55 & 5,45 & 6,65 \\
3280,05 & 525,17 & 13,85 & 6,15 & 7,69 \\
3268,23 & 505,53 & 13,15 & 6,85 & 8,65 \\
3262,32 & 457,09 & 12,46 & 7,54 & 9,04 \\
3256,41 & 385,20 & 11,76 & 8,24 & 8,79 \\
3262,32 & 330,86 & 11,06 & 8,94 & 8,66 \\
3250,50 & 282,56 & 10,36 & 9,64 & 8.51 \\
3256,41 & 223,87 & 9,66 & 10,34 & 7,72 \\
3250,50 & 174,69 & 8,96 & 11,04 & 6.92 \\
3244,59 & 129,11 & 8,26 & 11,74 & 5,90 \\
3226,86 & 67,37 & 7,56 & 12,44 & 3,57 \\
3220,95 & 0,00 & 7,10 & 12,90 & 0.00 \\
\hline
\end{tabular}




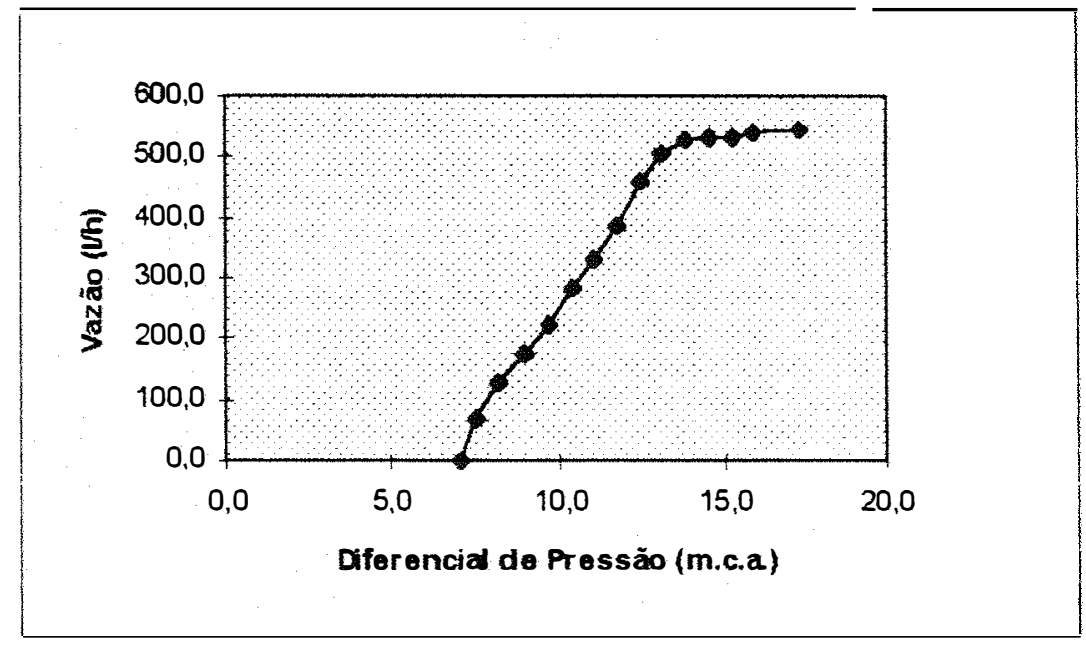

Figura 45. Vazão de sucção vs diferencial de pressão do injetor de 1" sob 20 m.c.a. de pressão de alimentação.

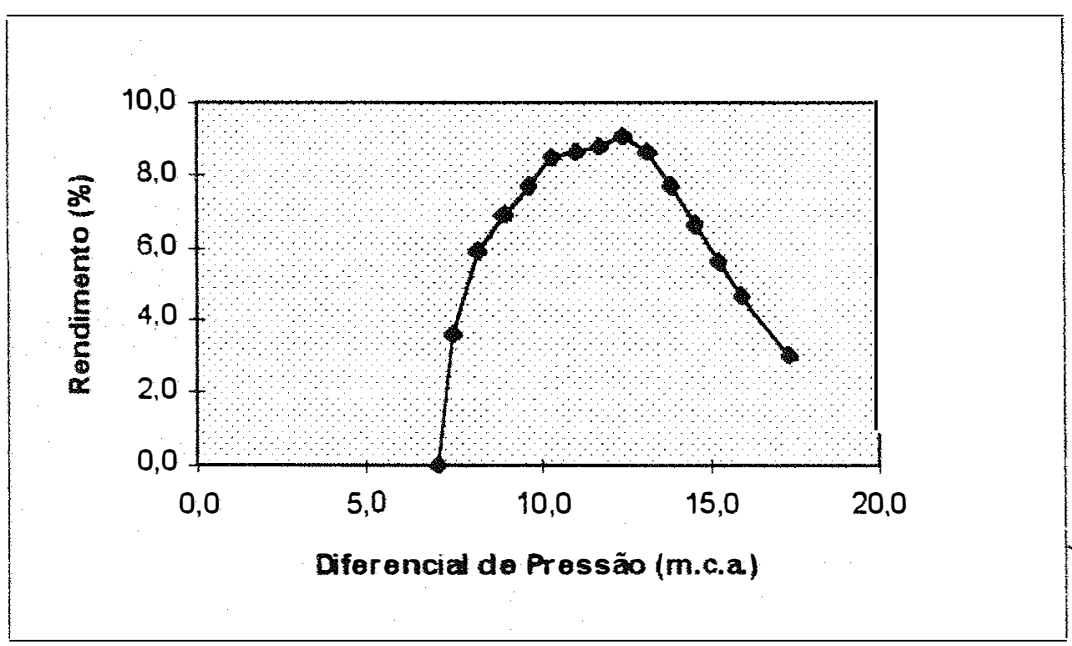

Figura 46. Diferencial de pressão vs rendimento do injetor de 1" sob pressão de alimentação de 20 m.c.a. 
Tabela 17. Pressão à jusante, diferencial de pressão, vazão de sucção, vazão de alimentação e rendimento do injetor de 1", succionando água, à pressão de alimentação de 15 m.c.a. sob tensão de sucção de 0,5 m.c.a.

\begin{tabular}{|c|c|c|c|c|}
\hline $\begin{array}{c}\text { Vazão de } \\
\text { alimentação } \\
(\mathrm{I} / \mathrm{h})\end{array}$ & $\begin{array}{c}\text { Vazão de } \\
\text { sucção } \\
(\mathrm{I} / \mathrm{h})\end{array}$ & $\begin{array}{c}\text { Diferencial de } \\
\text { pressão } \\
\text { (m.c.a.) }\end{array}$ & $\begin{array}{c}\text { Pressão } \\
\text { à jusante } \\
\text { (m.c.a.) }\end{array}$ & $\begin{array}{c}\text { Rendimento } \\
(\%)\end{array}$ \\
\hline 2712,69 & 608,22 & 12,58 & 2,42 & 5,20 \\
2721,56 & 601,83 & 12,35 & 2,65 & 5,64 \\
2715,65 & 595,78 & 12,12 & 2,88 & 6,12 \\
2709,74 & 585,13 & 11,88 & 3,12 & 6,58 \\
2715,65 & 542,88 & 11,65 & 3,35 & 6,61 \\
2706,78 & 512,63 & 11,42 & 3,58 & 6,77 \\
2700,87 & 485,91 & 11,18 & 3,82 & 6,95 \\
2706,78 & 452,46 & 10,95 & 4,05 & 6.95 \\
2706,78 & 422,32 & 10,72 & 4,28 & 6,96 \\
2706,78 & 404,42 & 10,48 & 4,52 & 7,16 \\
2700,87 & 392,69 & 10,25 & 4,75 & 7,45 \\
2703,83 & 348,71 & 10,02 & 4,98 & 7,05 \\
2697,92 & 337,64 & 9,79 & 5,21 & 7,30 \\
2697,92 & 330,33 & 9,55 & 5,45 & 7.63 \\
2697,92 & 302,29 & 9,32 & 5,68 & 7,43 \\
2694,96 & 266,13 & 9,09 & 5,91 & 6.96 \\
2694,96 & 256,90 & 8,85 & 6,15 & 7,16 \\
2692,01 & 229,97 & 8,62 & 6,38 & 6.82 \\
2689,05 & 197,42 & 8,39 & 6,61 & 6,22 \\
2689,05 & 161,97 & 7,92 & 7,08 & 5,77 \\
2686,01 & 121,55 & 7,46 & 7,54 & 4,88 \\
2686,01 & 62,92 & 6,99 & 8,01 & 2,85 \\
2674,28 & 0,00 & 6,52 & 8,48 & 0.00 \\
\hline
\end{tabular}




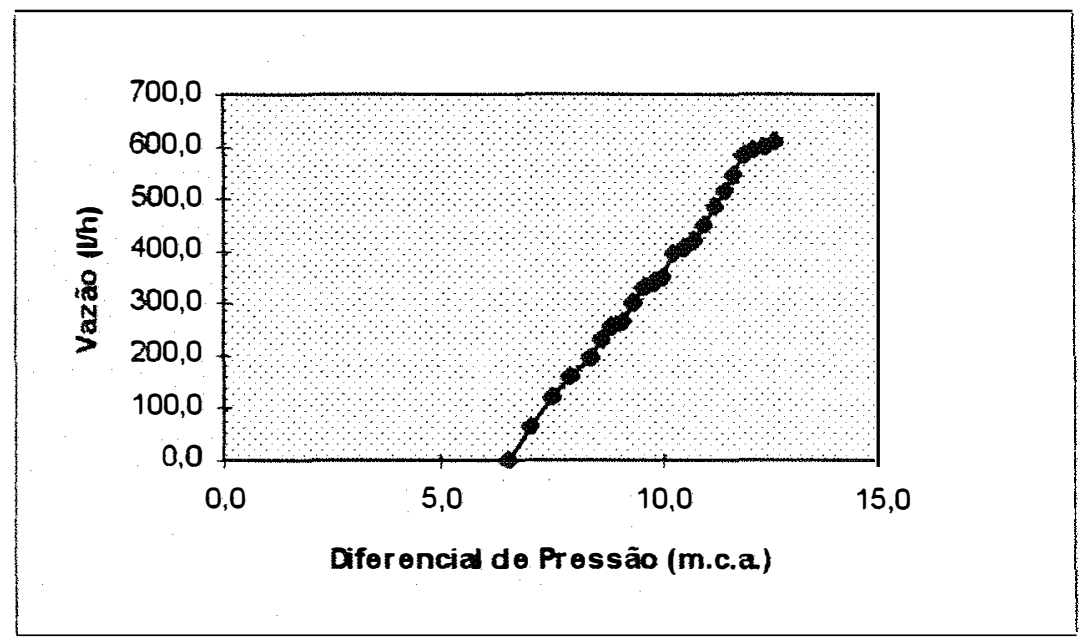

Figura 47. Vazão de sucção vs diferencial de pressão do injetor de 1" sob 15 m.c.a de pressão de alimentação.

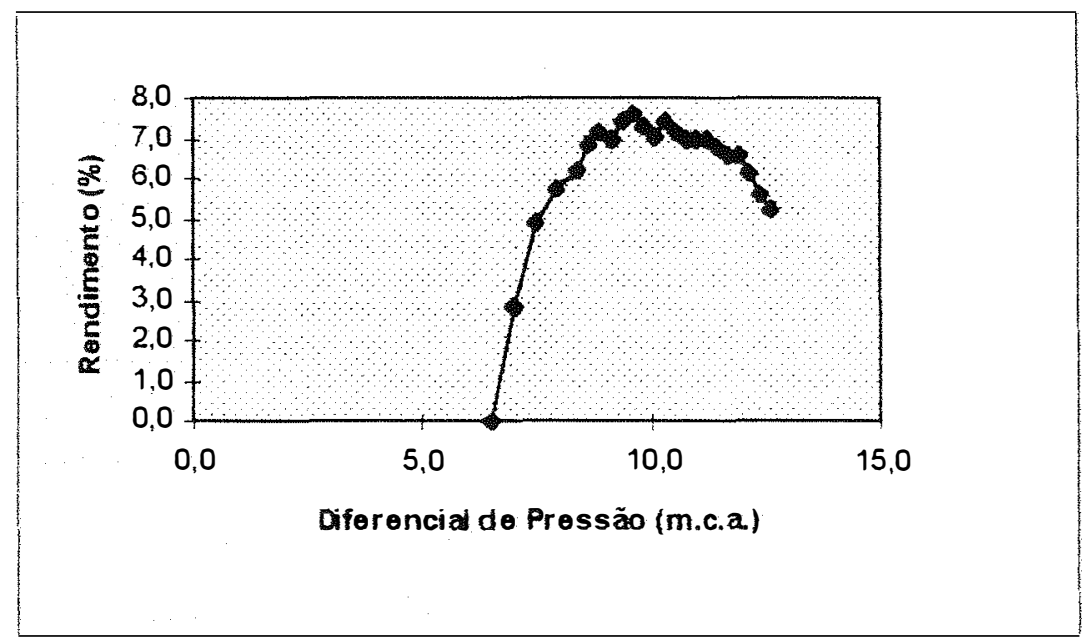

Figura 48. Diferencial de pressão vs rendimento do injetor de 1 " sob pressão de alimentação de 15 m.c.a. 
Tabela 18. Pressão à jusante, diferencial de pressão, vazão de sucção, vazão de alimentação, e rendimento do injetor de 1" succionando água, à pressão de alimentação de 10 m.c.a. sob tensão de sucção de 0,5 m.c.a.

\begin{tabular}{|c|c|c|c|r|}
\hline $\begin{array}{c}\text { Vazão de } \\
\text { alimentação } \\
(\text { I/h) }\end{array}$ & $\begin{array}{c}\text { Vazão de } \\
\text { sucção } \\
\text { (l/h) }\end{array}$ & $\begin{array}{c}\text { Diferencial de } \\
\text { pressão } \\
\text { (m.c.a.) }\end{array}$ & $\begin{array}{c}\text { Pressão } \\
\text { à jusante } \\
\text { (m.c.a.) }\end{array}$ & $\begin{array}{r}\text { Rendimento } \\
(\%)\end{array}$ \\
\hline 2251,71 & 624,00 & 8,05 & 1,95 & 8,43 \\
2242,85 & 579,43 & 7,81 & 2,19 & 8,90 \\
2233,98 & 556,82 & 7,58 & 2,42 & 9,60 \\
2228,07 & 514,95 & 7,35 & 2,65 & 9,91 \\
2219,21 & 451,48 & 7,12 & 2,88 & 9.66 \\
2254,67 & 448,23 & 6,88 & 3,12 & 10,46 \\
2213,30 & 361,82 & 6,65 & 3,35 & 9,46 \\
2168,97 & 352,53 & 6,42 & 3,58 & 10,33 \\
2160,11 & 303,66 & 6,18 & 3,82 & 9,83 \\
2239,89 & 287,71 & 5,95 & 4,05 & 9,82 \\
2160,11 & 241,37 & 5,72 & 4,28 & 9.34 \\
2174,88 & 201,58 & 5,48 & 4,52 & 8,49 \\
2183,75 & 167,59 & 5,25 & 4,75 & 7,67 \\
2228,07 & 137,95 & 5,02 & 4,98 & 6.76 \\
2154,20 & 111,16 & 4,79 & 5,21 & 6,15 \\
2204,43 & 31,75 & 4,32 & 5,68 & 2.06 \\
2163,06 & 0,00 & 4,09 & 5,91 & 0,00 \\
\hline
\end{tabular}




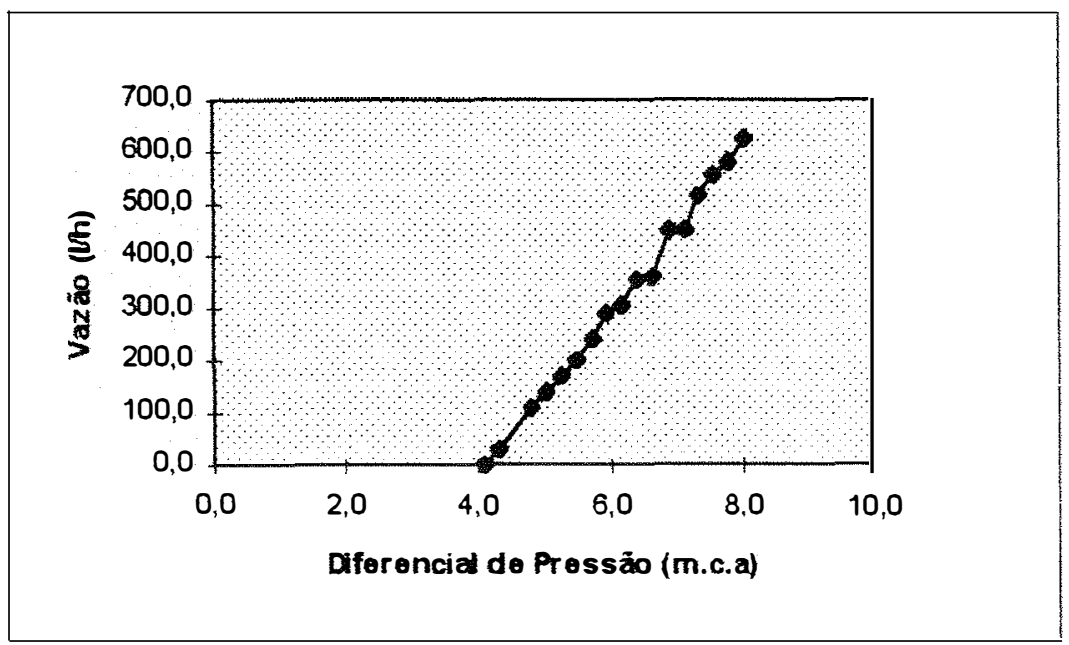

Figura 49. Vazão de sucção vs diferencial de pressão do injetor de 1" sob 10 m.c.a de pressão de alimentação.

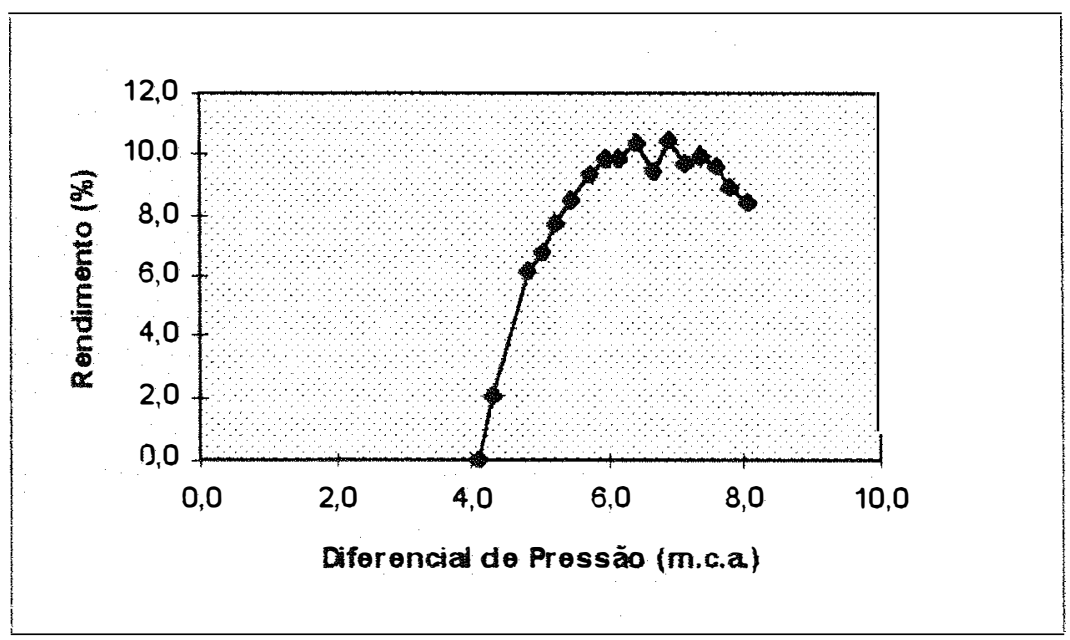

Figura 50. Curva do diferencial de pressão vs rendimento do injetor de 1" sob pressão de alimentação de 10 m.c.a. 


\section{CONCLUSÕES}

Com base nos resultados obtidos, para as condições nas quais foram conduzidos os experimentos, pode-se concluir que:

- O maior rendimento obtido com o injetor de $3 / 4 "$ foi de $8,21 \%$, sob pressão de alimentação de 10 m.c.a, tensão de sucção de 0,5 m.c.a., diferencial de pressão de 7,12 m.c.a., vazão de sucção de $117,47 \mathrm{l} / \mathrm{h}$ e vazão de alimentação de $679,65 \mathrm{l} / \mathrm{h}$.

- O maior rendimento obtido para o injetor de 1" foi de $10,46 \%$, sob pressão de alimentação de10 m.c.a., tensão de sucção, de 0,5 m.c.a., diferencial de pressão de 6,88 m.c.a.,vazão de sucção de 448,23 l/h e vazão de alimentação de $2254,67 \mathrm{l} / \mathrm{h}$.

- Ambos os injetores diminuem a sua vazão de suç̧ão, com o aumento da tensão de sucção.

- Ambos os injetores, nas pressőes de alimentação de 40, 35, 30, 25 e 20 m.c.a., possuem limites, a partir dos quais, mesmo que se aumente 0 diferencial de pressão, não aumenta a vazão de sucção. Já nas pressões de alimentação de 15 e 10 m.c.a., não foram encontrados tais limites e mantevese linear a relação entre vazão de sucção e diferencial de pressão. 


\section{REFERÈNCIAS BIBLIOGRÁFICAS}

AZEVEDO NETTO, J.M. \& ALVAREZ, G.A. Estudos dos Bocais. In:

Manual de hidráulica. 2.ed. São Paulo, Edgar Blucher, 1988. v.1, cap. 7, p. $67-71$.

BALLOFET, A.; GOTELLI, L.M.;MEOLI, G.A. Escurrimento en cañeria. In: Hidraulica . 2.ed. Buenos Aires, Ediar, 1955. v.2, cap. 7, p. 41-57. (Biblioteca Ediar de Ingenieria)

CARLIER, M. Machines hydrauliques. Paris, Imprimerie Louis-Jean, 1968.

DELMÉE, G.J. Manual de medição de vazão. 2.ed. São Paulo, Edgard Blucher, 1983. 476p.

DENÍCULI, W.; FEITOSA FILHO, J.C.;TORRES LOUREIRO, B.; AMARAL, F. Desempenho do injetor de fertilizante Venturi na fertimigação por microaspersão. Revista Ceres, Viçosa, 39 (226) : 554 - 63, nov./dez. 1992 
FEITOSA FILHO, J.C. Uniformidade de distribuição de fertilizantes via água de irrigação por microaspersão, com uso dos injetores tipo venturi e tanque de derivação, Viçosa, 1990. 77p. (M.S. - Universidade Federal de Viçosa).

FEITOSA FILHO, J.C. \& ARRUDA, N.T. Protótipo, dimensionamento e metodologia de construção de um injetor de produtos químicos "Tipo Venturi", metálico, para uso na quimigação. Trabalho apresentado no 230. Congresso Brasileiro de Engenharia Agricola. Campinas, 1994.

FERREIRA, J. O. P. Caracterízação hidráulica de dois injetores de fertilizantes do tipo venturi. Piracicaba, 1994. 76 p. (Mestrado - Escola Superior de Agricultura "Luiz de Queiroz" ( USP).

FRIZZONE, J.A.; BOTREL, T.A.; DOURADO NETO, D. Aplicação de fertilizantes via água de irrigação.Piracicaba, ESALQ / Departamento de Engenharia Rural, 1994.35p.

FUCHSLOCHER, E. Bombas de chorro de agua y de vapor. In: Bombas; manual para escuelas de ingenieros. 8 Ed. Barcelona, Labor, 1954. cap. 4 , p.203 - 8.

HERNÁNDEZ ABRÉU,J.M.; RODRIGO LÓPEZ, J.; PÉREZ REGALADO,A.; GONZÁLEZ HERNÁNDEZ, J.F. Fertilizadores tipo Venturi. In:

El riego localizado - Curso internacional de riego localizado Tenerife.(España). Madrid, INIA. 1987. p.67-8. 
HIRSCHMANN, R.J. Características de los distintos tipos de bombas. In:_ Bombas; características y aplicación. Santiago de Chile, Universitária, 1958. cap. 4, p.85 - 139.

OLIVEIRA, E.F. Análise do desempenho de hidro-ejetores funcionando como bomba de vácuo, Piracicaba, 1993, 64p. (Mestrado - Escola Superior de Agricultura "Luiz de Queiroz"/USP)

PIZARRO CABELLO, F. Inyector Venturi. In: . Riegos localizados de alta frequencia (RLAF) goteo, microaspersión, exudación. 2.ed. Madrid, Mundi-Prensa, 1990. p.316-8.

RUSSELL, G.E. El medidor Venturi. In:_Hidraulica. Mexico, Compañia Editorial Continental, 1971, p.298-303.

SHANI, M. \& SAPIR, E. Fertilization in irrigation. Netanya, CINADCO, 1986. 44p.

SNE, M. Fertigation. Netanya, CINADCO, 1988. 10p.

TROSKOLÁNSKI, A.T. Dispositifs d'appareils a jet. In:__. Les turbopompes; théorie, tracé et construction. Paris, Eyrolles, 1977, cap. 16, p.329-33. 
URQUHART, L.C. Civil engineering handbook. 3.ed. New York, Mc Graw-Hill, 1950.

VENNARD, J.K. \& STREET, R.L. Medidor Venturi. In: Elementos de mecánica dos fluidos. 5.ed. Rio de Janeiro, Guanabara Dois, 1978, p.516-8 